\title{
Flow of partially molten crust controlling construction, growth and collapse of the Variscan orogenic belt: the geologic record of the French Massif Central
}

\author{
Olivier Vanderhaeghe ${ }^{1, *}$, Oscar Laurent ${ }^{1,2}$, Véronique Gardien ${ }^{3}$, Jean-François Moyen ${ }^{4}$, Aude Gébelin ${ }^{5}$, \\ Cyril Chelle-Michou ${ }^{2}$, Simon Couzinié ${ }^{4,6}$, Arnaud Villaros ${ }^{7,8}$ and Mathieu Bellanger ${ }^{9}$ \\ ${ }^{1}$ GET, UPS, CNRS, IRD, 14, avenue E. Belin, F-31400 Toulouse, France \\ ${ }^{2}$ ETH Zürich, Institute for Geochemistry and Petrology, Clausiusstrasse 25, CH-8038 Zürich, Switzerland \\ 3 Université Lyon 1, ENS de Lyon, CNRS, UMR 5276 LGL-TPE, F-69622 Villeurbanne, France \\ ${ }^{4}$ Université de Lyon, Laboratoire Magmas et Volcans, UJM-UCA-CNRS-IRD, 23, rue Dr. Paul Michelon, 42023 Saint-Étienne, France \\ 5 School of Geography, Earth and Environmental Sciences, Plymouth University, Plymouth, UK \\ ${ }^{6}$ Université de Lorraine, CNRS, CRPG, F-54000 Nancy, France \\ ${ }^{7}$ Univ d'Orléans, ISTO, UMR 7327, 45071, Orléans, France; CNRS, ISTO, UMR 7327, 45071 Orléans, France; BRGM, ISTO, \\ UMR 7327, BP 36009, 45060 Orléans, France \\ ${ }^{8}$ University of Stellenbosch, Department of Earth Sciences, 7602 Matieland, South Africa \\ 9 TLS Geothermics, 91, Chemin de Gabardie, 31200 Toulouse, France
}

Received: 6 July 2019 / Accepted: 21 April 2020

\begin{abstract}
We present here a tectonic-geodynamic model for the generation and flow of partially molten rocks and for magmatism during the Variscan orogenic evolution from the Silurian to the late Carboniferous based on a synthesis of geological data from the French Massif Central. Eclogite facies metamorphism of mafic and ultramafic rocks records the subduction of the Gondwana hyperextended margin. Part of these eclogites are forming boudins-enclaves in felsic HP granulite facies migmatites partly retrogressed into amphibolite facies attesting for continental subduction followed by thermal relaxation and decompression. We propose that HP partial melting has triggered mechanical decoupling of the partially molten continental rocks from the subducting slab. This would have allowed buoyancy-driven exhumation and entrainment of pieces of oceanic lithosphere and subcontinental mantle. Geochronological data of the eclogite-bearing HP migmatites points to diachronous emplacement of distinct nappes from middle to late Devonian. These nappes were thrusted onto metapelites and orthogneisses affected by MP/MT greenschist to amphibolite facies metamorphism reaching partial melting attributed to the late Devonian to early Carboniferous thickening of the crust. The emplacement of laccoliths rooted into strike-slip transcurrent shear zones capped by low-angle detachments from c. 345 to c. $310 \mathrm{Ma}$ is concomitant with the southward propagation of the Variscan deformation front marked by deposition of clastic sediments in foreland basins. We attribute these features to horizontal growth of the Variscan belt and formation of an orogenic plateau by gravitydriven lateral flow of the partially molten orogenic root. The diversity of the magmatic rocks points to various crustal sources with modest, but systematic mantle-derived input. In the eastern French Massif Central, the southward decrease in age of the mantle- and crustal-derived plutonic rocks from c. $345 \mathrm{Ma}$ to c. $310 \mathrm{Ma}$ suggests southward retreat of a northward subducting slab toward the Paleotethys free boundary. Late Carboniferous destruction of the Variscan belt is dominantly achieved by gravitational collapse accommodated by the activation of low-angle detachments and the exhumation-crystallization of the partially molten orogenic root forming crustal-scale LP migmatite domes from c. $305 \mathrm{Ma}$ to c. $295 \mathrm{Ma}$, coeval with orogen-parallel flow in the external zone. Laccoliths emplaced along low-angle detachments and intrusive dykes with sharp contacts correspond to the segregation of the last melt fraction leaving behind a thick accumulation of refractory LP felsic and mafic granulites in the lower crust. This model points to the primordial role of partial melting and magmatism in the tectonic-geodynamic evolution of the Variscan
\end{abstract}

\footnotetext{
${ }^{*}$ Corresponding author: 0livier.vanderhaeghe@get.omp.eu
} 
orogenic belt. In particular, partial melting and magma transfer (i) triggers mechanical decoupling of subducted units from the downgoing slab and their syn-orogenic exhumation; (ii) the development of an orogenic plateau by lateral flow of the low-viscosity partially molten crust; and, (iii) the formation of metamorphic core complexes and domes that accommodate post-orogenic exhumation during gravitational collapse. All these processes contribute to differentiation and stabilisation of the orogenic crust.

Keywords: Variscan belt / French Massif Central / flow of partially molten crust / orogenic magmatism / orogenic plateau / Gravitational collapse

Résumé - Impact du fluage de la croûte partiellement fondue sur la construction, la croissance et
l'effondrement de la ceinture orogénique Varisque : l'enregistrement géologique du Massif Central français. Nous présentons dans ce papier un modèle géodynamique-tectonique pour la genèse et le fluage des roches partiellement fondues et le magmatisme au cours de l'évolution orogénique Varisque du Silurien au Carbonifère supérieur basé sur une synthèse des données géologiques du Massif Central Français. La subduction de la marge du Gondwana hyper-étirée est enregistré par des roches mafiques et ultramafiques affectées par un métamorphisme en faciès éclogitique. Ces éclogites forment pour certaines des boudinsenclaves dans des migmatites felsiques avec des reliques de faciès granulitique de HP retrogradées en faciès amphibolitique, ce qui atteste de la subduction de la marge continentale suivie d'une relaxation thermique et d'une décompression. Nous proposons que la fusion partielle à HP ait déclenché le découplage mécanique entre la plaque plongeante et les unités continentales partiellement fondues. Ceci a permis l'exhumation de ces roches gravitairement instables qui ont entrainé sur leur passage des blocs de lithosphère océanique et de manteau sous-continental. Les données géochronologiques disponibles sur les migmatites de HP contenant des éclogites indique une mise en place diachronique de nappes du Dévonien moyen au Dévonien Supérieur. Ces nappes ont chevauché un assemblage de métapélites et d'orthogneiss affectées par un métamorphisme de MP/MT allant du faciès schistes verts à amphibolite atteignant localement la fusion partielle et attribué à l'épaississement crustal du Dévonien supérieur au Carbonifère moyen. La mise en place de laccolithes enracinés dans des zones de cisaillement décrochantes et surmontés de détachements à faible pendage de $\mathrm{c}$. 345 à c. $310 \mathrm{Ma}$ est synchrone de la propagation vers le Sud du front de déformation Varisque marqué par le dépôt de sédiments détritiques dans les bassins d'avant-pays. Nous attribuons ces éléments à la croissance horizontale de la ceinture Varisque associée à la formation d'un plateau orogénique par fluage latéral de la racine orogénique partiellement fondue sous l'effet de la force gravitaire. La diversité des roches magmatiques témoigne d'une variété des sources crustales avec une contribution relativement modeste mais systématique de magmas issus du manteau. Dans la partie Est du Massif Central Français, la décroissance vers le Sud des âges de mise en place des magmas dérivés à la fois du manteau et de la croûte suggère le retrait d'un panneau plongeant vers le Nord vers la bordure libre constituée par la Paléotethys et située au Sud de la ceinture Varisque. La destruction de la chaine Varisque à la fin du Carbonifère est principalement le résultat de l'effondrement gravitaire accommodé par l'activation de détachements à faible pendage et l'exhumation-cristallisation de la racine orogénique partiellement fondue formant des dômes d'échelle crustale à cœur de migmatites de BP entre c. 305 et $295 \mathrm{Ma}$, concomitante au fluage latéral des unités de la zone externe de la chaine. Les derniers magmas extraits de la zone de fusion partielle forment des dykes et des laccolithes mis en place dans des détachements à faible pendage laissant derrière eux une croûte inférieure constituée de l'accumulation de granulites réfractaires de composition felsique à mafique. Ce modèle met en valeur le rôle primordial de la fusion partielle et du magmatisme sur l'évolution tectoniquegéodynamique de la ceinture orogénique Varisque. En particulier, la fusion partielle et le transfert de magma (i) déclenchent le découplage mécanique entre le panneau plongeant et les unités subductées, permettant ainsi l'exhumation de ces dernières, (ii) favorisent le développement d'un plateau orogénique par fluage latéral de la croûte partiellement fondue de faible viscosité sous l'effet de la gravité, (iii) conduisent à la formation de metamorphic core complex et de domes qui accommodent l'exhumation post-orogénique au cours de l'effondrement gravitaire de la chaine. Tous ces processus contribuent à la différenciation et à la stabilisation de la croûte orogénique.

Mots clés : Ceinture Varisque / Massif Central Français / fluage d'une croûte partiellement fondue / magmatisme orogenique / plateau orogenique / effondrement gravitaire

\section{Introduction}

Migmatites and granites are the main constituents of the continental crust and their petrogenesis and emplacement are intimately linked to orogenic evolution (Thompson and Connolly, 1995; Sawyer, 1998; Brown, 2001; Foster et al., 2001; Vanderhaeghe, 2009; Sawyer et al., 2011; Weinberg, 2016;
Závada et al., 2018). Various heat sources have been proposed to cause high-temperature metamorphism and partial melting of orogenic roots comprising an increase in radioactive heat production of the thickened crust, an increase in the basal heat flux associated with delamination of the lithospheric mantle and heat advection through the emplacement of mantle-derived magmas (Houseman et al., 1981; England and Thompson, 1984; 


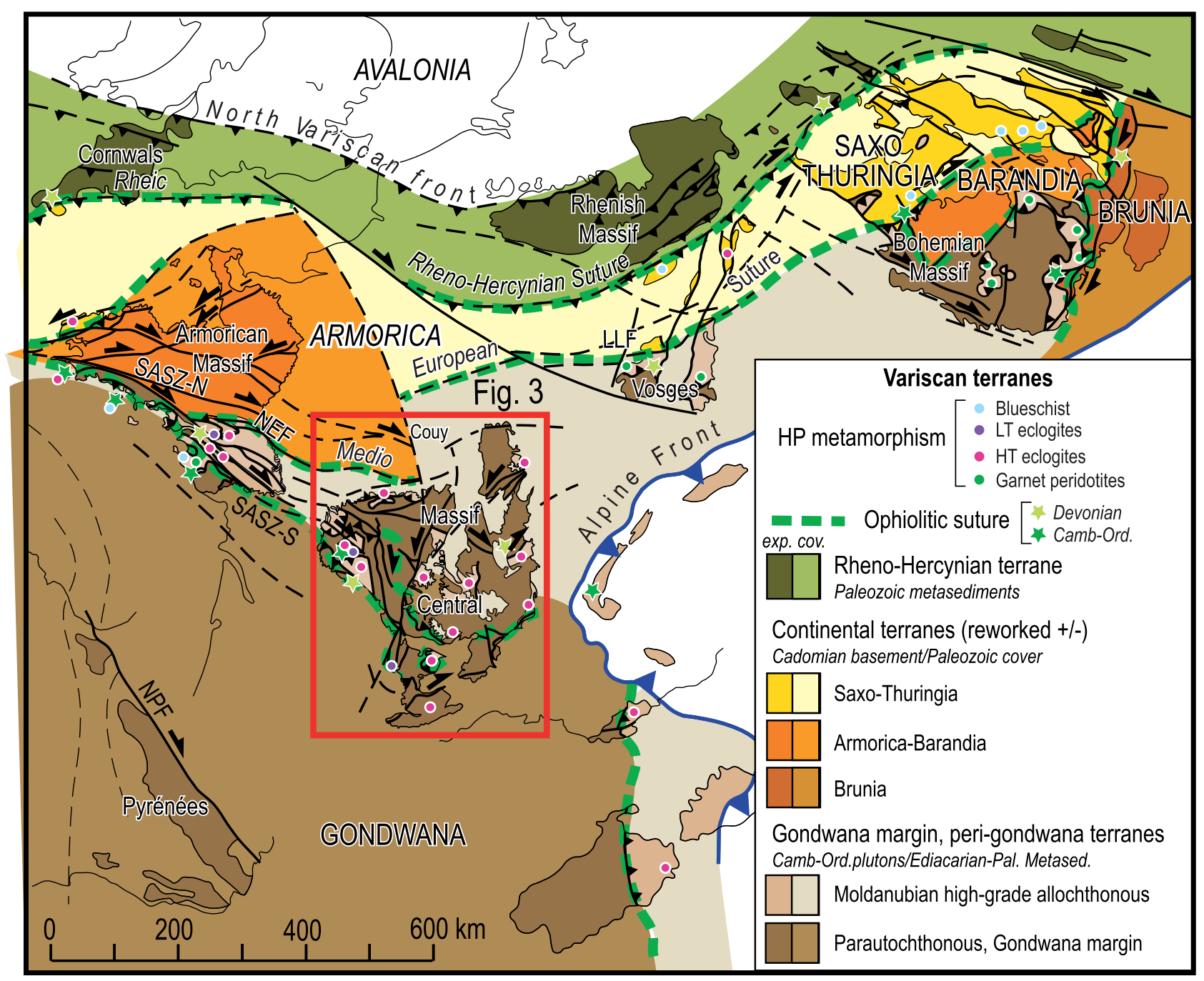

Fig. 1. Tectonic map of the Variscan belt in Western Europe. Continental terranes, Avalonia, Saxo-Thuringia, Armorica-Barandia, Brunia, are separated by ophiolitic sutures, namely the Rheic suture and the Medio-European suture, to the north and south of Armorica respectively. The internal zone of the Variscan belt comprises high-grade nappes overlying a parautochtonous unit belonging to the northern margin of Gondwana.

Henk et al., 2000; Annen and Sparks, 2002; Vanderhaeghe et al., 2003; Vanderhaeghe and Duchêne, 2010; Ueda et al., 2012). In turn, partial melting has a profound impact on the rheology at the scale of the rock and at the one of the entire crust (Vigneresse et al., 1996; Brown and Solar, 1998; Solar et al., 1998; Rosenberg, 2001; Vanderhaeghe and Teyssier, 2001a, 2001b; Gébelin et al., 2006; Schulmann et al., 2008; Vanderhaeghe, 2009), which is expressed by an intimate link between deformation and melt/solid segregation (Sawyer, 1994; Brown and Rushmer, 1997; Brown and Solar, 1998; Weinberg and Searle, 1998; Vanderhaeghe, 1999; Hasalová et al., 2008; Hasalova et al., 2011; Weinberg et al., 2013). Partial melting potentially triggers mechanical decoupling of the subducted continental crust from the downgoing slab as it has been proposed for example in the Norwegian Caledonides or the Variscan Bohemian Massif (Labrousse et al., 2011; Gordon et al., 2016; Závada et al., 2018). Partial melting has also been identified as the key parameter controlling lateral flow of the deep root of orogenic belts through the activation of vertical shear zones (Solar et al., 1998; Weinberg and Mark, 2008) leading to the formation of orogenic plateaux (Vanderhaeghe and
Teyssier, 2001a, 2001b; Vanderhaeghe et al., 2003; Gerbault et al., 2005; Cagnard et al., 2006; Chardon et al., 2009). Finally, the ubiquitous presence of large domes cored by migmatites in the exhumed roots of orogenic belts (Whitney et al., 2004; Vanderhaeghe, 2009) as well as the spatial-temporal correlations between the emplacement of granitic laccoliths and the activation of low-angle detachments (Lister and Baldwin, 1993; Vanderhaeghe, 1999; Searle et al., 2009; Whitney et al., 2013) suggest that the presence of a partially molten crust and the migration of granitic melts controls the behaviour of the orogenic crust during orogenic gravitational collapse.

The Variscan belt of Western Europe (Fig. 1) has long been recognized as particularly rich in migmatites and granitoids (e.g. Zwart, 1967) and is thus the perfect target to investigate the impact of partial melting and magmatism on orogenic evolution. The large spread of radiochronological ages obtained on migmatites and magmatic rocks (from c. $390 \mathrm{Ma}$ to c. $290 \mathrm{Ma}$ ) and the wide variety of petrological and geochemical characteristics of the magmatic rocks indicate that the $100 \mathrm{Ma}$ long tectonic history of the Variscan belt has been punctuated by the emplacement of magmas 
implying the contribution of both the crust and the mantle (Letterrier, 1978; Cuney et al., 1990; Solgadi et al., 2007; Bussien et al., 2008; Couzinié et al., 2014; von Raumer et al., 2014; Laurent et al., 2017). In addition to the identification of the sources and geodynamic context of these magmas, arises the question of the impact of low-viscosity and low-density silicate melts on the dynamic evolution of the Variscan orogen.

Despite the significant exposure of migmatites and granitoids, their implication on the tectonic evolution of the Variscan belt has not been fully explored, to the noticeable exceptions of some papers on the French Massif Central (Malavieille et al., 1990; Burg and Vanderhaeghe, 1993; Costa and Rey, 1995; Vanderhaeghe et al., 1999) and Central Iberia, the Vosges, and Bohemia (Henk, 2000; Henk et al., 2000; Schulmann et al., 2008, 2014; Lardeaux et al., 2014; Rubio Pascual et al., 2016). The goal of this paper is to discuss the impact of partial melting and magmatism on the tectonic evolution of the Variscan orogenic belt of Western Europe based on a synthesis of structural, petrological, geochemical, geochronological and sedimentological data available for the Variscan basement of the French Massif Central. This region offers a unique section through the Variscan crust that recorded, from Silurian to Permian, a prolonged history of burial and exhumation associated with the construction and destruction of the belt, respectively. The tectonic evolution is particularly marked by the generation of migmatites under HP, MP and LP metamorphic conditions and by varied plutonic rocks emplaced from the middle Devonian to the early Permian. This history is complemented by the P-T-t record of lower crustal xenoliths brought back to the surface by Cenozoic volcanoes and by unmetamorphosed to low-grade volcano-sedimentary series deposited from the middle Devonian (Givetian) to the Permian that constrain the topographic evolution of the belt.

In this paper, we propose a new geodynamic model for the generation and flow of partially molten rocks and magmas during orogenic evolution from construction by tectonic accretion of subducted continental units followed by lateral growth of the orogenic belt associated with construction of an orogenic plateau and eventually to gravitational collapse. This geodynamic model is also nourished by new data recently published in companion papers comprising (i) Lu-Hf tracing of igneous and detrital zircon in gneisses and plutonic rocks (Chelle-Michou et al., 2017; Couzinié et al., 2017, 2019), (ii) $\mathrm{U}-\mathrm{Pb}$ dating of zircon and monazite by LA-ICP-MS on the Carboniferous plutonic rocks (Chelle-Michou et al., 2017; Laurent et al., 2017) and (iii) a detailed petrogenetic model for these granitoids (Moyen et al., 2017).

\section{Geology of the French Massif Central: a window through the Variscan belt}

\subsection{The Variscan belt: continental blocks, oceanic sutures, allochthonous terranes and paleogeographic reconstructions}

The Variscan belt has been first defined as a post-Cambrian and pre-Permian mobile belt based on analysis of stratigraphic unconformities, structures and nappes (Suess, 1883; Bertrand, 1887). It is extending from East Asia to the tip of South America running through Central Europe and along the edges of North America (Matte, 2001). Paleomagnetic data indicate that the Variscan belt formed as a consequence of the convergence between Laurussia (Laurentia + Baltica) and Gondwana resulting in the Pangea supercontinent (Scotese and McKerrow, 1990; Unrug, 1997; Tait et al., 2000). However, the number of oceanic sutures and the former sizes of the oceanic basins are discussed as developed below.

Pioneer work correlating data from the eastern (Bohemia) and western (Iberia) terminations of the belt led to (i) the definition of the main geological-tectonic zones, (ii) the identification of the principal Paleozoic tectonic events based on the relationship between structures and Ediacaran to Carboniferous sedimentary deposits in the external zone and along the foreland, and (iii) the recognition of high-grade nappes in the internal zone (Stille, 1924; Kossmat, 1927; Gaertner, 1937; Demay, 1948; Gèze, 1949). The relationship between sedimentation and deformation, best exposed along its external domains, allowed the identification of continental blocks such as Avalonia, Armorica, Saxo-Thuringia, Barrandia and Brunia, all of which preserve Cambrian unconformities more or less affected by Variscan deformation and metamorphism (Matte, 1986, 1991; Franke and Engel, 1986; Franke, 1989, 2000; Kroner and Romer, 2013). These continental blocks are separated by oceanic sutures marked by ophiolitic assemblages or mélanges. All authors agree on the Rheic suture, also called the Lizard-Rheno-Hercynian suture, that corresponds to the former Rheic Ocean, to the south of Avalonia and to the north of Saxo-Thuringia and Armorica (Fig. 1) (Matte, 1991; Franke, 2000; Ballèvre et al., 2014; Franke et al., 2017). The nature of the terranes and the presence of sutures south of Armorica is however debated. Despite uncertainties, we favor the existence of multiple sutures (designated as "secondary sutures" on Fig. 1) based on (i) the presence of ultramafic and mafic high-pressure rocks of different ages at different structural levels (Girardeau et al., 1986; Dubuisson et al., 1989; Faure et al., 1997; Bosse et al., 2000; Ballèvre et al., 2009; Berger et al., 2006, 2010a; Lardeaux, 2014; Lardeaux et al., 2014; Lotout et al., 2018), and (ii) the occurrence of remnants of subordinate Devonian rift and/or oceanic basins (Sider and Ohnenstetter, 1986; Skrzypek et al., 2012).

In the French Massif Central, until the middle of the 20th century, the prevailing model attributed the high-grade granitic-gneisses to a crystalline basement and the paragneisses and schists to a sedimentary cover deposited from the Neoproterozoic throughout the Paleozoic (Jung, 1953; Roques, 1971). In the absence of geochronological data, metamorphism was considered as polycyclic, the basement being metamorphosed during the Neoproterozoic, and then, together with its sedimentary cover, during the Caledonian and the Variscan orogenies (Forestier, 1961; Chenevoy and Ravier, 1971; Roques, 1971). This view has been profoundly modified first by the results of absolute dating demonstrating ubiquitous Variscan reworking (Gebauer et al., 1981; Pin and Lancelot, 1982; Rolin et al., 1982; Duthou et al., 1994). Another turning point was to interpret the felsic/mafic gneisses with a tholeiitic signature, defined as the Leptynite-Amphibolite Complex (LAC), as remnants of ophiolites (Forestier, 1961; Briand and Piboule, 1979; Cabanis et al., 1983; Maillet et al., 1984; Mercier et al., 1985; Piboule and Briand, 1985; Briand et al., 1988; Dubuisson et al., 1989; Pin, 1990). In the Armorican Massif, ophiolites define the Medio-European suture also 

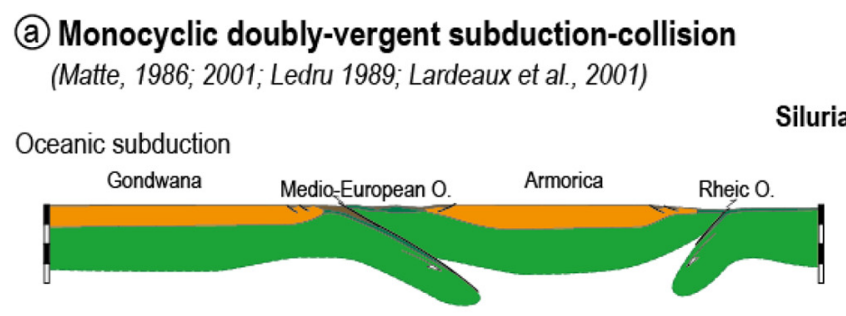

Early Devonian ( $390 \mathrm{Ma})$ Silurian $(\sim 420 \mathrm{Ma})$

\section{(b) Polycyclic subduction-collision}

(Faure et al., 1997; 2002; 2008; 2009; Lardeaux et al., 2014)
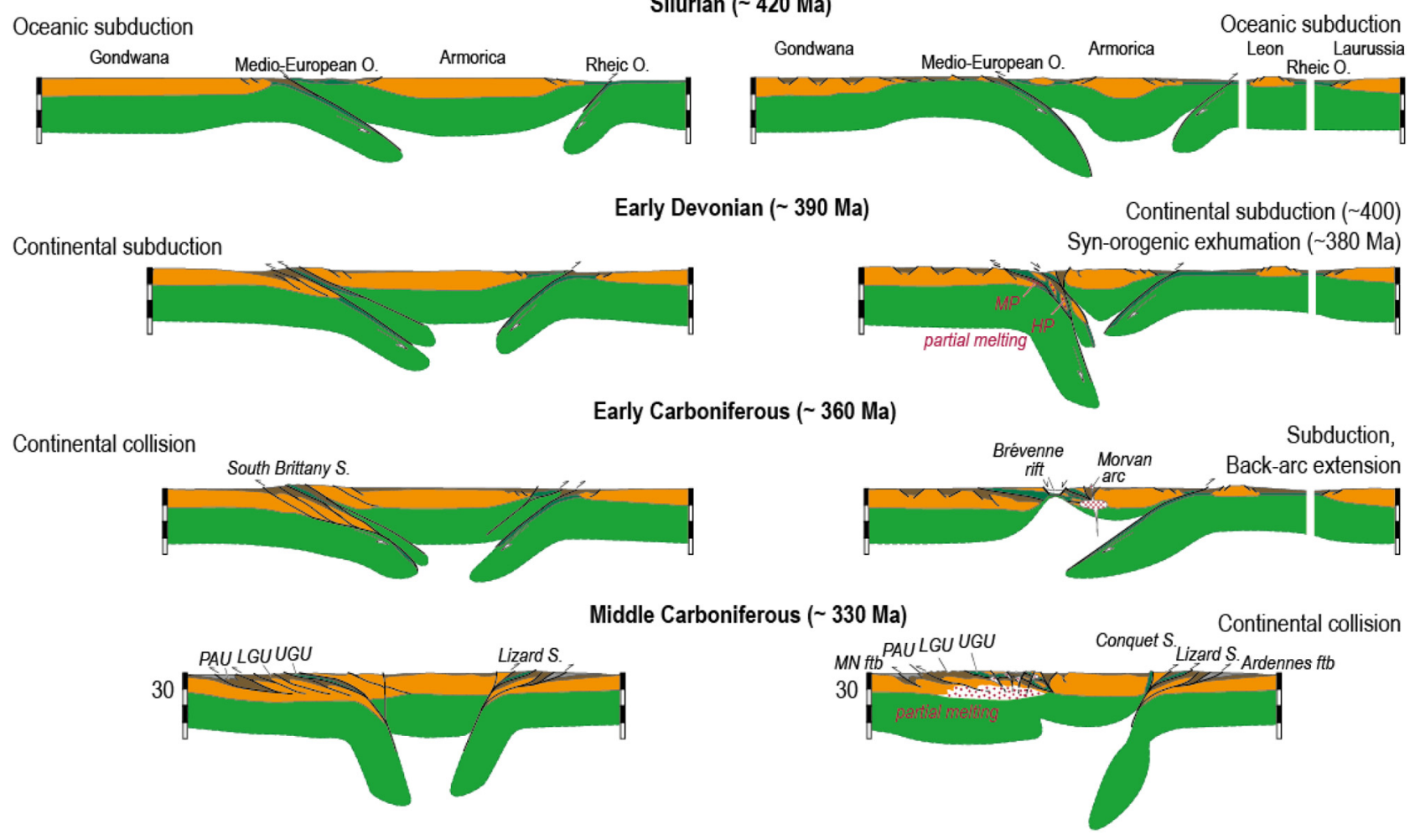

Fig. 2. Geodynamic-tectonic models and paleogeographic reconstructions for evolution of the Variscan belt of Western Europe. A. The double subduction model (modified after Matte, 1986, 1991, 2001). B. The polycyclic model (modified after Faure et al., 1997, 2002, Faure et al., 2009a, 2009b and Lardeaux et al., 2014). C. Single (Rheic) Ocean model of Paris and Robardet (1990); Martínez Catalán et al. (2001); Nance et al. (2010). D. Mutliple Oceans (Rheic, Medio-European, ...) model of Tait et al. (1997); Matte (2001); Stampfli and Borel (2004); Domeier and Torsvik (2014).

referred to as the Galicia-South Brittany suture, or the Eo-Variscan suture (Bernard-Griffiths and Cornichet, 1985; Hanmer, 1977; Faure et al., 1997; Ballèvre et al., 2009). This suture corresponds to the former Medio-European Ocean (also designated as the Galicia-Massif Central Ocean or the Paleotethys Ocean) that is located to the south of the Armorica-Barrandia continental block (Matte, 1986, 2001; Pin, 1990; Stampfli et al., 2013) (Fig. 1).

Based on this analysis, most authors agree that the Variscan belt of Western Europe results from tectonic accretion of the Avalonia and Armorica ribbon-shaped continental terranes and the closure of intervening oceanic basins, marked by (i) the Iapetus-Tornquist suture north of Avalonia, (ii) the Rheic/ Rheno-Hercynian suture between Avalonia and Armorica (Matte, 2001; von Raumer et al., 2003) and (iii) the MedioEuropean suture between Armorica and Gondwana (Matte, 1986, 2001; Pin, 1990; Stampfli et al., 2013) (Figs. 2A and 2B). All models invoke closure of the Iapetus Ocean during the Ordovician concomitantly to the rapid opening of the Rheic Ocean (e.g. Hamilton and Murphy, 2004) by reactivation of a Neoproterozoic suture along the northern Gondwana margin (Linnemann et al., 2007). The driving force for this oceanisation has been attributed either to slab pull from the northward subducting Iapetus (Murphy et al., 2006) or to roll-back of a southward subducting slab beneath the Gondwana margin (Martínez Catalán et al., 2009). Paleogeographic reconstruction differ for the early Ordovician period with regard to the position of Armorica that has implications on the existence and size of the Medio-European Ocean (Tait et al., 2000; Matte, 2001; Martínez Catalán et al., 2007, 2009; Faure et al., 2008; Ballèvre et al., 2009; Shail and Leveridge, 2009; Nance et al., 2010; Torsvik et al., 2012; Kroner and Romer, 2013; Stampfli et al., 2013; Lardeaux, 2014; Lardeaux et al., 2014; Schulmann et al., 2014; Skrzypek et al., 2014; Edel et al., 2018). Indeed, sedimentologic and paleontological data lead to paleogeographic reconstructions indicating a position close to the South Pole for Gondwana together with Avalonia and Armorica, and between the tropics and the equator for Laurentia and Baltica (Paris and Robardet, 1990; Robardet et al., 1993; Fortey and Cocks, 2003; Robardet, 2003). This is consistent with paleomagnetic data indicating an Iapetus Ocean at least $3000 \mathrm{~km}$ wide (Tait et al., 2000; Cocks and Torsvik, 2002; Hamilton and Murphy, 2004). On the other hand, some paleomagnetic data indicate that Armorica remained attached to the Gondwana margin until the Devonian (Kössler et al., 1996), which is consistent with the continuity of benthic faunas from Armorica to the northern margin of Gondwana (Robardet, 2003) while other paleomagnetic data indicate that Armorica moved toward Laurussia during the Ordovician (Tait et al., 2000), implying closure of the Rheic Ocean and opening of a 2000-3000 km wide Medio-European Ocean (Tait et al., 1997; Cocks and Torsvik, 2006; Shaw and Johnston, 2016). As a 


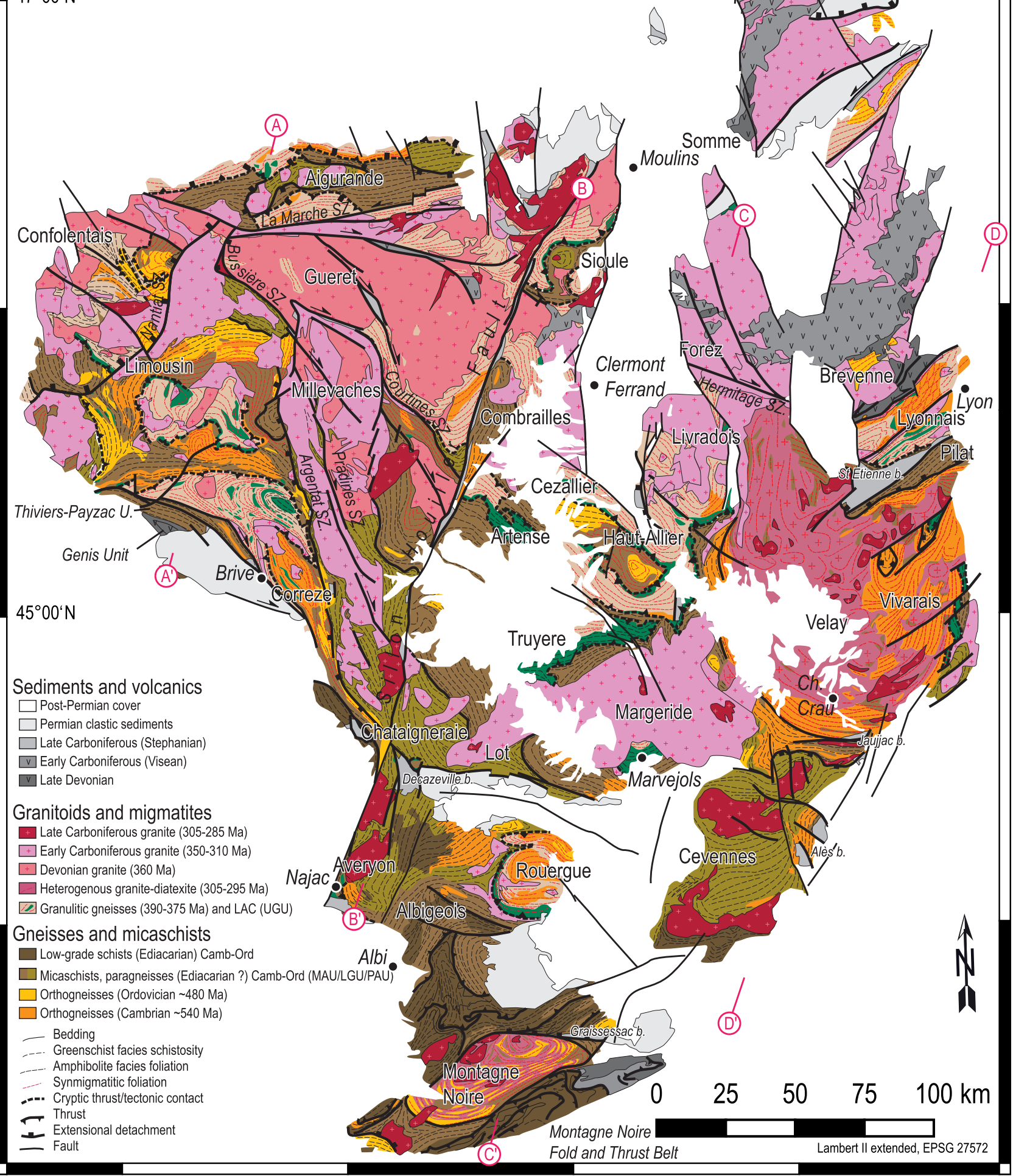


result, two paleogeographic reconstructions clash, one favoring a large Medio-European Ocean between Gondwana and a continental ribbon including Armorica (Matte, 2001; von Raumer et al., 2003; Stampfli and Borel, 2004; Domeier and Torsvik, 2014; Domeier, 2016), while the other considers at most a small immature rift in this region and infer that the large oceanic realm is the Rheic Ocean (Martínez Catalán et al., 2007; Nance et al., 2010; Kroner and Romer, 2013) (Figs. 2C and 2D). On the other hand, tectonic reconstructions based on geological data implying multiple rifts and/or oceanic basins in between Armorica and Gondwana (Girardeau et al., 1986; Dubuisson et al., 1989; Faure et al., 1997; Lardeaux, 2014; Lardeaux et al., 2014), correspond to an intermediate proposition.

\subsection{The main lithologic-tectonic units of the French Massif Central}

The French Massif Central is one of the largest exposures of the Variscan belt of Western Europe. Its geology is synthesized with reference to 1:1000000 scale map (Chantraine et al., 1996, 2003) and to the lithologic-tectonic units defined on the basis of their distinct lithological, structural, metamorphic and geochronological record (Burg and Matte, 1978; Matte, 1986; Ledru et al., 1989; Quenardel et al., 1991; Faure et al., 2009a; Lardeaux, 2014). According to these authors, the French Massif Central is made of (i) low- to high-grade metamorphic nappes with a Devonian to Carboniferous tectonic record, (ii) late Devonian to late Carboniferous plutonic rocks, (iii) late Devonian to Carboniferous volcanic and carbonate to clastic sedimentary rocks affected by lowgrade metamorphism, and (iv) unconformable late Carboniferous and Permian detrital sediments (Fig. 3). The French Massif Central is subdivided into a western part and an eastern part by the NNE-SSW trending Sillon Houiller Fault (Arthaud and Matte, 1975; Feybesse, 1981) (Fig. 3). The latter crosscuts a set of NW-SE to NNW-SSE trending dextral shear zones that is particularly well-developed in the western part of the French Massif Central and connects to the South Armorican shear zone (Lerouge and Quenardel, 1988; Gébelin et al., 2007). The nappe pile is also cross-cut by low-angle detachements (Malavieille et al., 1990; Burg et al., 1993; Faure, 1995; Gardien et al., 1997; Bellot, 2007).

\subsubsection{Metamorphic nappes}

The interpretation of the LAC as a suture marking the boundary between an Upper Gneiss Unit (UGU) and a Lower Gneiss Unit (LGU) led to the reinterpretation of the structure of the FMC in terms of nappe stacking (Burg and Matte, 1978; Ledru et al., 1989) but also to comparisons between the Variscan belt of Western Europe and the Himalaya-Tibet orogen (Dewey and Burke, 1973; Mattauer and Etchecopar, 1976; Burg and Matte, 1978; Autran and Cogné, 1980; Bard et al., 1980; Matte, 1986, 1991). Since its first description, the definition of the LAC has fluctuated and appears to cover a variety of rocks, with emphasis either on the bimodal magmatic association or on the high-pressure metamorphism affecting the mafic and ultramafic rocks (see discussion in Santallier et al., 1988). In addition, the LAC has been recognized at different structural positions and characterized by various metamorphic conditions and ages that led to the addition of a Middle Allochthonous Unit (MAU) in an intermediate position between the UGU and LGU (Girardeau et al., 1986; Dubuisson et al., 1989; Berger et al., 2010a, 2010b; Lotout et al., 2018). The proposed superposition of the UGU (and of the MAU) over the LGU relies on contrasted metamorphic record delineating an inverted metamorphic gradient and locally on the identification of tectonic contacts (Faure et al., 1979; Burg et al., 1984). Based on these characteristics, the main units of the metamorphic nappe stack are, from top to bottom (Tab. 1):

- The Upper Gneiss Unit (UGU): It is made of garnet/ cordierite-bearing diatexites associated with metatexites derived from orthogneisses and paragneisses with relics of granulite facies mineral parageneses. It has recorded a typical maximum pressure of $10 \mathrm{kbar}$ for a temperature up to $900{ }^{\circ} \mathrm{C}$ retrogressed into amphibolite facies and greenschist facies pointing to decompression and cooling (Audren et al., 1987; Lardeaux et al., 2001; Schulz et al., 2001; Bellot and Roig, 2007; Schulz, 2009) (Fig. 4). Geochronological data are consistent with a Devonian to early Carboniferous age for these HP granulite facies migmatites (Duthou et al., 1981, 1994; Lafon, 1986; Schulz, 2014; Do Couto et al., 2016). The Upper Gneiss Unit contains boudins and enclaves of the Leptynite Amphibolite Complex (LAC) that have preserved HT eclogitic relics first discovered in the Haut-Allier and in the Rouergue (Forestier, 1961; Lasnier, 1968; Nicollet, 1977) but then found in most if not all of the LAC enclosed in the UGU (Burg and Matte, 1978; Gardien and Lardeaux, 1991; Mercier et al., 1991a, 1991b; Gardien, 1993). These eclogites have typically recorded PT conditions of c. 15 kbar for c. $750^{\circ} \mathrm{C}$ (Santallier, 1981; Le Breton et al., 1986; Godard, 1990; Bellot and Roig, 2007) but more extreme conditions above $28 \mathrm{kbar}$ are reported in the Lyonnais (Lardeaux et al., 2001) (Fig. 4). The few available geochronological data for the French Massif Central have served to propose a late Silurian to Devonian age for this HT eclogite facies metamorphism (Pin and Lancelot, 1982; Ducrot et al., 1983; Paquette et al., 1995; Do Couto et al., 2016).

- The Middle Allochthonous Unit (MAU): Identified in Limousin, it consists mainly of micaschists associated with an ophiolitic assemblage that is similar to the Leptynite Amphibolite Complex. In contrast to the Upper Gneiss Unit, the LAC of the MAU is marked by relics of LT

\footnotetext{
Fig. 3. Geological map of the French Massif Central (modified after Chantraine et al., 2003). Metamorphic rocks comprise (i) a low-grade metasedimentary sequence attributed to the Lower Paleozoic (Cambrian to Lower Carboniferous), (ii) micaschists and paragneisses of uncertain age but considered as Neoproterozoic to Lower Paleozoic deposits, (iii) orthogneisses with a Cambrian or Ordovician age. The Middle Allochthonous Unit, the Parautochtonous Unit and the Lower Gneiss Unit are made of these metasedimentary rocks and orthogneisses. The Upper Gneiss Unit is characterized by relics of granulite facies metamorphism and by enclaves-boudins of mafic and ultramafic rocks affected by eclogite facies metamorphism, designated as the Leptynite-Amphibolite Complex (LAC). The color scheme of magmatic rocks is indicative of their age. Granitoids are distinguished according to their petrologic types in Figure 6.
} 
Table 1. Geochronological constraints on emplacement or deposition of pre-Variscan rocks in the French MassifCentral. $1=$ Melleton et al., 2010; $2=$ Alexandrov et al., 2001; $3=$ Alexandre, 2007; $4=$ Lafon, 1986; $5=$ Bernard-Griffiths, 1975; 6= Bernard-Griffiths et al., 1977; 7= Gebauer et al., 1981; 8 = Berger et al., 2010b; 9 = Lasserre et al., 1980; 10 = Paquette et al., 1995; 11 = Pin and Lancelot, 1978; 12= Pin and Lancelot, 1982; $13=$ Maurel et al., 2003; $14=$ Faure et al., 2017; $15=$ Lotout et al., 2017; 16 = Ducrot et al., 1979; 17 = Cocherie et al., 2005; 18 = Pitra et al., 2012; $19=$ Roger et al., 2004; 20 = Lescuyer and Cocherie, 1992; $21=$ Trap et al., 2017; 22 = Couzinié et al., 2017; 23= Caen-Vachette, 1979; 24 = Bé Mézémé et al., 2006; 25 = R'Kha Chaham et al., 1990; 26= Couzinié et al., 2017; 27= Chelle-Michou et al., 2017; $28=$ Duthou et al., 1981.

\begin{tabular}{|c|c|c|c|c|c|}
\hline Region & Location & Rock type & Method & Age (Ma) & Refs \\
\hline \multicolumn{6}{|c|}{ West French Massif Central } \\
\hline Aigurande & & Migmatitic paragneiss & U-Pb Zircon LA-ICPMS & $<558 \pm 9$ & 1 \\
\hline \multirow[t]{18}{*}{ Limousin } & Thiviers-Payzac Unit & Metasandstone & U-Pb Zircon LA-ICPMS & $<564 \pm 9$ & 1 \\
\hline & Cornil & Paragneiss & U-Pb Zircon LA-ICPMS & $<573 \pm 12$ & 1 \\
\hline & Seilhac & Paragneiss & U-Pb Zircon LA-ICPMS & $<523 \pm 4$ & 1 \\
\hline & Mllevache & Micaschist (S \& E Argentat) & U-Pb Zircon LA-ICPMS & $<604 \pm 16 ;<631 \pm 18$ & 1 \\
\hline & Aubazine & Micaschist & U-Pb Zircon LA-ICPMS & $<593 \pm 4$ & 1 \\
\hline & Vergonzac & Leptynite & U-Pb Zircon ion probe & $525 \pm 12$ & 2 \\
\hline & Thaurion & Orthogneiss & U-Pb Zircon ion probe & $457 \pm 23$ & 3 \\
\hline & Moulin du Chambon & Orthogneiss & U-Pb Zircon LA-ICPMS & $529 \pm 4$ & 1 \\
\hline & Meuzac & Orthogneiss & U-Pb Zircon LA-ICPMS & $451 \pm 5$ & 1 \\
\hline & Saut du Saumon & Orthogneiss & U-Pb Zircon LA-ICPMS & $501 \pm 5$ & 1 \\
\hline & Tulle & Orthogneiss & U-Pb Zircon LA-ICPMS & $470 \pm 11$ & 1 \\
\hline & Aubazine & Orthogneiss & U-Pb Zircon LA-ICPMS & $475 \pm 11$ & 1 \\
\hline & Meuzac and St Yriex-La-Perche & Calc-alkaline orthogneiss & U-Pb Zir / Rb-Sr (WR) & $495 \pm 8 ; 468 \pm 8$ & 4,5 \\
\hline & Saut-du-Saumon & Calc-alkaline orthogneiss & $\mathrm{Rb}-\mathrm{Sr}$ (whole rock) & $476 \pm 22 ; 461 \pm 22$ & 5,6 \\
\hline & Thaurion & Calc-alkaline orthogneiss & Rb-Sr (whole rock) & $514 \pm 24$ & 6 \\
\hline & Clair vivre & Metarhyolite & U-Pb Zircon LA-ICPMS & $475 \pm 6$ & 1 \\
\hline & Sauviat & Mafic gneisses & U-Pb Zircon TIMS & $496+25 /-17$ & 7 \\
\hline & Roche-l'Abeille & Zoisite-eclogite & U-Pb Zircon LA-ICPMS & $473 \pm 6$ & 8 \\
\hline \multicolumn{6}{|c|}{ East French Massif Central } \\
\hline Haut-Allier & Saint-Flour & Metaleucogranite & $\mathrm{Rb}-\mathrm{Sr}$ whole rock & $569 \pm 17$ & 9 \\
\hline Rouergue & $\begin{array}{l}\text { La Bessenoits } \\
\text { La Bessenoits } \\
\text { Palanges } \\
\text { Caplongue } \\
\end{array}$ & \begin{tabular}{|l|} 
Norite \\
Eclogite \\
Orthogneiss \\
Diorite \\
\end{tabular} & $\begin{array}{l}\text { U-Pb Zircon TIMS } \\
\text { U-Pb Zircon TIMS } \\
\text { U-Pb Zircon TIMS } \\
\text { U-Pb Zircon TIMS }\end{array}$ & $\begin{array}{l}481 \pm 1 \\
475 \pm 18 \\
600 \pm 10 \\
557+12 /-10 \\
\end{array}$ & $\begin{array}{l}10 \\
10 \\
10 \\
4 \\
\end{array}$ \\
\hline Lot & \begin{tabular}{|l} 
Picades \\
Marvejols \\
Marvejols \\
Marvejols
\end{tabular} & \begin{tabular}{|l} 
Diorite \\
Metarhyolite \\
Metagabbro \\
Amphibolic gneiss
\end{tabular} & $\begin{array}{l}\text { U-Pb Zircon TIMS } \\
\text { U-Pb Zircon TIMS } \\
\text { U-Pb Zircon TIMS } \\
\text { U-Pb Zircon TIMS }\end{array}$ & $\begin{array}{l}540 \pm 15 \\
478 \pm 6 \\
484 \pm 7 \\
487 \pm 6\end{array}$ & $\begin{array}{l}11 \\
12 \\
12 \\
12 \\
\end{array}$ \\
\hline Mt Noire & $\begin{array}{l}\text { Plaisance } \\
\text { Somail } \\
\text { Saint-Eutrope } \\
\text { Gorges d'Héric } \\
\text { Pont-de-Larn } \\
\text { Sériès } \\
\text { Albine } \\
\text { Albine } \\
\text { Lodève } \\
\text { Lodève } \\
\text { Col du Layrac } \\
\text { Orbiel } \\
\end{array}$ & $\begin{array}{l}\text { Orthogneiss } \\
\text { Orthogneiss } \\
\text { Orthogneiss } \\
\text { Orthogneiss } \\
\text { Orthogneiss } \\
\text { Metadacite } \\
\text { Orthogneiss } \\
\text { Orthogneiss } \\
\text { Metasandstone } \\
\text { Metarhyolite } \\
\text { Metarhyolite } \\
\text { Metasandstone } \\
\end{array}$ & $\begin{array}{l}\text { U-Pb Zircon TIMS } \\
\text { U-Pb Zircon ion probe } \\
\text { U-Pb Zircon LA-ICPMS } \\
\text { U-Pb Zircon TIMS } \\
\text { U-Pb Zircon TIMS } \\
\text { U-Pb Zircon } \\
\text { U-Pb Zircon LA-ICPMS } \\
\text { U-Th-Pb Monazite LA-ICPMS } \\
\text { U-Pb Zircon LA-ICPMS } \\
\text { U-Pb Zircon LA-ICPMS } \\
\text { U-Pb Zircon LA-ICPMS } \\
\text { U-Pb Zircon LA-ICPMS }\end{array}$ & $\begin{array}{l}532 \pm 13 \\
471 \pm 4 \\
455 \pm 2.2 \\
450 \pm 6 \\
456 \pm 3 \\
545 \pm 15 \\
472.1 \pm 2.8 \\
470.4 \pm 4.7 \\
<574.0 \pm 6.1 \\
542.5 \pm 0.7 \\
537.1 \pm 2.5 \\
<602.5 \pm 7.3 \\
\end{array}$ & $\begin{array}{l}16 \\
17 \\
18 \\
19 \\
19 \\
20 \\
21 \\
21 \\
22 \\
22 \\
22 \\
22 \\
\end{array}$ \\
\hline Pilat & & Metarhyolite & $\mathrm{Rb}-\mathrm{Sr}$ whole rock & $545 \pm 14$ & 23 \\
\hline Velay & $\begin{array}{l}\text { Puylaurent } \\
\text { Arc-de-Fix } \\
\text { St Privat d'Allier } \\
\text { Col de Meyrand } \\
\text { Labastide-Puylaurent } \\
\text { Langogne } \\
\text { Tournon } \\
\text { Tournon } \\
\text { Tournon } \\
\text { Tournon } \\
\end{array}$ & $\begin{array}{l}\text { Migmatite } \\
\text { Orthogneiss } \\
\text { Orthogneiss } \\
\text { Orthogneiss } \\
\text { Orthogneiss } \\
\text { Orthogneiss } \\
\text { Orthogneiss } \\
\text { Amphibolite } \\
\text { Granite (orthogneiss prot.) } \\
\text { Migmatitic paragneiss } \\
\end{array}$ & $\begin{array}{l}\text { U-Th-Pb Monazite microprobe } \\
\text { Rb-Sr whole rock } \\
\text { U-Pb Zircon LA-ICPMS } \\
\text { U-Pb Zircon LA-ICPMS } \\
\text { U-Pb Zircon LA-ICPMS } \\
\text { U-Pb Zircon LA-ICPMS } \\
\text { U-Pb Zircon LA-ICPMS } \\
\text { U-Pb Zircon LA-ICPMS } \\
\text { U-Pb Zircon LA-ICPMS } \\
\text { U-Pb Zircon LA-ICPMS }\end{array}$ & $\begin{array}{l}543 \pm 25 / 550 \pm 86 \\
528 \pm 9 \\
541.8 \pm 3.1 \\
542.5 \pm 3.1 \\
541.4 \pm 2.3 \\
545.9 \pm 4.3 \\
482.2 \pm 3.8 ; 477.6 \pm 2.2 ; 481.4 \pm 2.5 \\
486.4 \pm 3.1 \\
550.2 \pm 3.1 ; 544.3 \pm 3.1 \\
<550\end{array}$ & $\begin{array}{l}24 \\
25 \\
26 \\
26 \\
26 \\
26 \\
27 \\
27 \\
27 \\
27\end{array}$ \\
\hline Lyonnais & Saint-André-la-Côte & Granulite & $\mathrm{Rb}-\mathrm{Sr}$ whole rock & $497 \pm 8$ & 28 \\
\hline
\end{tabular}



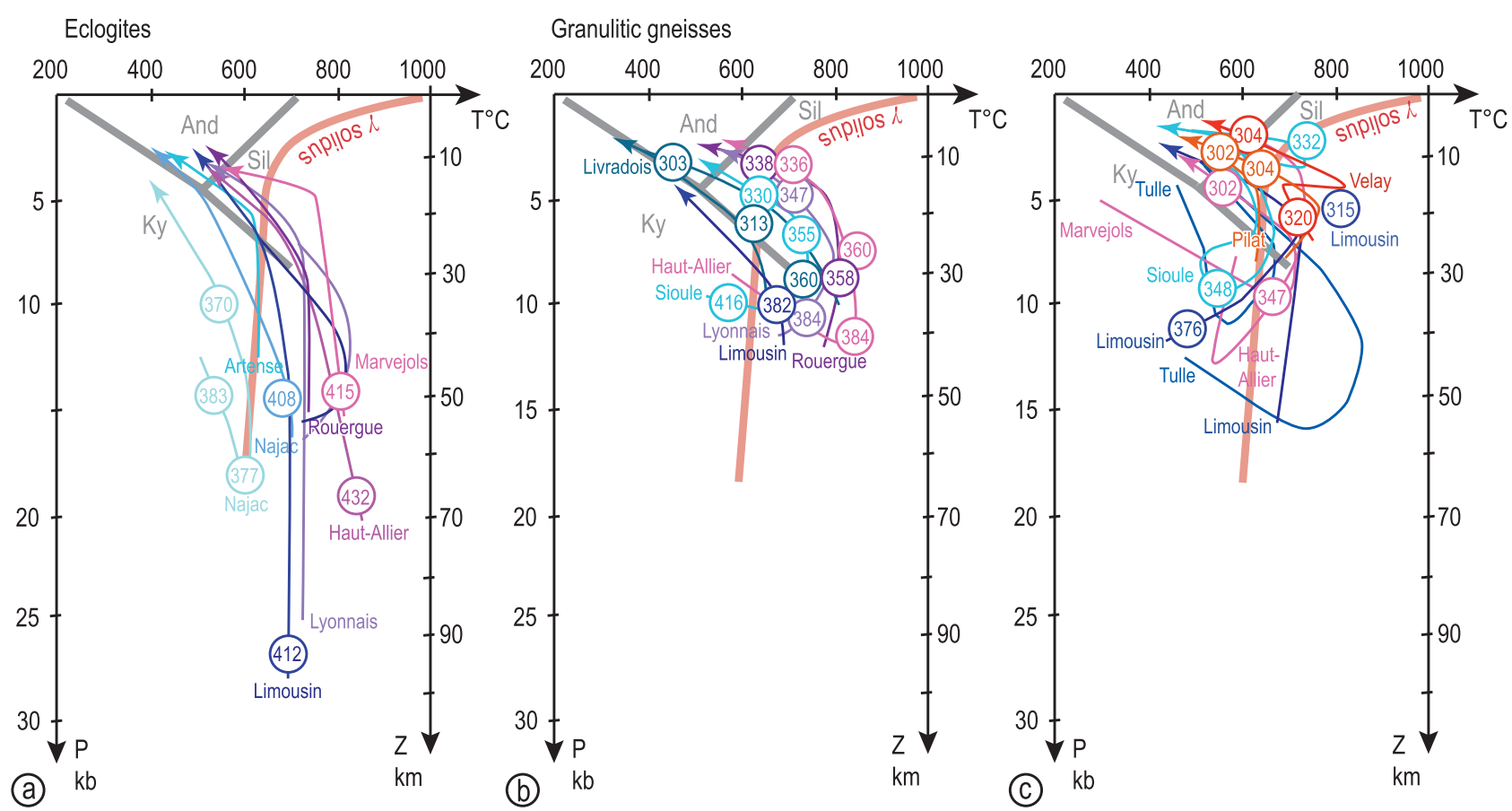

Fig. 4. Synthetic P-T-t paths of the Upper Gneiss Unit, Middle Allochthonous Unit, and of the Lower Gneiss Unit. The Upper Gneiss Unit is made of granulitic migmatites enclosing mafic and ultramafic enclaves of the Leptynite-Amphibolite Complex, whereas the Middle Allochthonous is not migmatitic. A. The Leptynite-Amphibolite Complex contains UHP and eclogitic relics dated at the transition from late Silurian to late Devonian as indicated by the numbers in the circles (c. 432 to c. $377 \mathrm{Ma}$ ). B. These rocks are retrogressed into the granulite facies dated from the middle to the late Devonian (c. 384 to c. $360 \mathrm{Ma}$ ) in the migmatitic gneisses of the Upper Gneiss Unit. C. The Lower Gneiss Unit comprises rare HP/LT rocks in the Limousin dated at c. $376 \mathrm{Ma}$. Rocks of the Lower Gneiss Unit have also recorded early Carboniferous (348-320 Ma) and late Carboniferous (304-302 Ma) LP amphibolite facies metamorphism.

eclogite facies metamorphism (Girardeau et al., 1986; Dubuisson et al., 1989; Berger et al., 2010a, 2010b). The maximum pressure recorded by a garnet-kyanite assemblage is $29 \mathrm{kbar}$ but the temperature did not exceed $660^{\circ} \mathrm{C}$ consistent with subduction to $100 \mathrm{~km}$ depth (Berger et al., 2010a) (Fig. 4). The pressure peak in Najac is $18 \mathrm{kbar}$ and the temperature only reached $600^{\circ} \mathrm{C}$ (Lotout et al., 2018). These rocks have then been retrogressed into amphibolite facies. Published geochronological data for this LT eclogite facies metamorphism point to a late Silurian age in Central Limousin (Berger et al., 2010a) and middle Devonian in Najac (Lotout et al., 2018).

- The Lower Gneiss Unit (LGU): It is made of micaschists, paragneisses and felsic orthogneisses with minor carbonates and mafic rocks. The LGU is affected by greenschist to amphibolite facies metamorphism depicting a Carboniferous Barrovian MP/MT gradient reaching partial melting locally masked by retrogression into greenschist facies (Nicollet, 1978; Burg et al., 1984, Burg et al., 1989a, 1989b; Schulz et al., 2001; Gébelin et al., 2009; Gardien et al., 2011) (Fig. 4).

- The Para-Autochtonous Unit (PAU): It is made of micaschists, paragneisses and orthogneisses affected by pervasive Carboniferous greenschist facies metamorphism locally preserving relics of amphibolite facies (Bellot and Roig, 2007) (Fig. 4).
These high-grade nappes, identified throughout the French Massif Central, are structurally overlain by Metamorphic Upper Units (MUU) with limited lateral extent:

- The Thiviers-Payzac Unit: It marks the western edge of the Limousin (Fig. 3). It is made of Cambrian-Ordovician metasedimentary rocks (Bellot and Roig, 2007). The lower part of the Thiviers-Payzac Unit is composed by an assemblage of metagabbros, metadolerites and pyroxenebearing layered amphibolites (Santallier, 1981; Bellot and Roig, 2007) suspected to represent an ophiolitic mélange.

- The Génis Unit: It overlies the Thiviers-Payzac Unit (Fig. 3). It is composed of unmetamorphosed gabbro, dolerite, basalt and cherts (Cabanis et al., 1983; Maillet et al., 1984)-associated with Ordovician-Devonian sericite micaschist and middle Devonian limestones (Guillot and Doubinger, 1971; Guillot and Lefevre, 1975). This assemblage has been interpreted to represent a middle Devonian ophiolitic mélange (Ledru et al., 1989) or a late Devonian - early Carboniferous olistostrome reworking a Devonian ophiolite (Faure et al., 2009a).

- The Somme Unit: It is exposed south of the Morvan (Fig. 3). It is characterized by middle to late Devonian unmetamorphosed weakly deformed sedimentary and volcanic rocks (Delfour et al., 1989). Marine carbonates of Givetian and Frasnian age alternate with calc-alkaline volcanics and volcaniclastics associated with massive 
sulphide deposits and are capped by Famennian clastic sediments (Delfour et al., 1989). This association is consistent with the construction of a magmatic arc along a convergent active margin (Faure et al., 2008).

- The Brévenne Unit. It is located south of the Morvan and north of the Monts du Lyonnais (Fig. 3). It comprises ultramafics, gabbros, pillow basalts, siliceous sedimentary rocks and massive sulphide deposits attributed to a late Devonian ophiolitic sequence (Bébien, 1971; Sider and Ohnenstetter, 1986; Pin, 1990; Bitri et al., 1999; Leloix et al., 1999; Pin and Paquette, 2002; Milési and Lescuyer, n.d.). Volcanics display contrasting low-K calc-alkaline to tholeiitic signatures, suggesting an emplacement in an immature back-arc basin (Bébien, 1971; Pin and Lancelot, 1982; Sider and Ohnenstetter, 1986; Pin, 1990; Pin and Paquette, 1997). These magmatic rocks have been dated at $366 \pm 5 \mathrm{Ma}$ and $358 \pm 1 \mathrm{Ma}$ by U-Pb on zircon (Pin and Paquette, 1997).

\subsubsection{Protoliths age for the high-grade rocks, basement of} the Devonian to Carboniferous volcanic and sedimentary units

The first proposed ages for the different lithological units exposed in the French Massif Central relied on relative chronology based on stratigraphy, biostratigraphy and crosscutting relationships (Jung, 1953; Roques, 1971). The intensity of metamorphism and deformation affecting rocks forming the UGU, MAU, and LGU precludes the identification of fossils in high-grade metasedimentary rocks and the recognition of initial magmatic-sedimentary contacts. Thus, protoliths age determination relying mostly on analogies with stratigraphic ages determined in other regions are subject to caution. Recent age determinations based on radiometric dating of inherited zircon grains (distinguished from Variscan metamorphic zircon) provide (i) a maximum age (the youngest age obtained on inherited grains) for the deposition of the sediments protoliths of paragneisses, and (ii) a crystallization age for magmatic rocks, protoliths of orthogneisses, and/or amphibolites and other mafic metaplutonics. Ages spreading from the late Neoproterozoic (Ediacaran) to the early Paleozoic (Cambrian to Ordovician) have been attributed to most of the metasedimentary sequences (Franke, 2000; Chantraine et al., 2003; Linnemann et al., 2007). Protoliths ages of metamorphic rocks (Pin and Duthou, 1990; R'Kha Chaham et al., 1990; Duthou et al., 1994; Melleton et al., 2010; ChelleMichou et al., 2017; Couzinié et al., 2017, 2019; Lotout et al., 2018) (Fig. 5) indicate (i) an Ediacaran to Ordovician age for metasediments deposited along the former margin of the Gondwana continent, (ii) Ediacaran, Cambrian and Ordovician ages for orthogneisses, and (iii) a Cambrian to Ordovician age for the mafic and ultramafic rocks (Tab. 2). According to these data, the only identified Proterozoic basement in the French Massif Central corresponds to the paragneisses and orthogneisses with Ediacaran protoliths.

\subsubsection{Migmatites and granulites}

In addition to the HP granulite facies migmatites that are part of the UGU, MP and LP migmatites, developed to the expense of late Neoproterozoic to early Paleozoic paragneisses and orthogneisses, are exposed at the lowest structural level of the nappe pile in the Limousin, Velay and Montagne Noire (Williamson et al., 1996; Downes et al., 1997; Ledru et al., 2001; Gébelin et al., 2009; Barbey et al., 2015; Villaros et al., 2018). In the Limousin, PT conditions of $850-750^{\circ} \mathrm{C}$ and $5-$ $6 \mathrm{kbar}$ have been estimated for the cordierite-bearing migmatitic gneisses and associated lenses of leucosomes of the Millevaches massif in the Limousin dated at c. $315 \mathrm{Ma}$ (Gébelin et al., 2009). In the Montagne Noire, migmatites coring the Caroux dome have recorded P-T conditions of $6 \mathrm{kbar}$ and $720^{\circ} \mathrm{C}$ (Rabin et al., 2015). They contain magmatic zircon with $\mathrm{U}-\mathrm{Pb}$ ages spreading from c. 330 to c. $300 \mathrm{Ma}$ (Franke et al., 2011; Faure et al., 2014; Roger et al., 2015). In the Velay dome, migmatites display contrasting P-T conditions and ages as a function of their structural position. Along the margin of the dome, migmatites have recorded partial melting with biotite remaining stable at a pressure over $5 \mathrm{kbar}$ for a temperature over $750^{\circ} \mathrm{C}$ (Montel et al., 1992). These migmatites contain monazite that yield microprobe $\mathrm{U}-\mathrm{Pb}$ ages ranging from c. 329 to $314 \mathrm{Ma}$ (Mougeot et al., 1997; Cocherie et al., 2005; Bé Mézémé et al., 2006). In contrast, migmatites coring the Velay dome have recorded fluid-absent biotite melting in the cordierite stability field with P-T estimates of 2 $5 \mathrm{kbar}$ and $760-850^{\circ} \mathrm{C}$ (Montel et al., 1992; Barbey et al., 1999, 2015; Villaros et al., 2018). These migmatites display a $\mathrm{Rb}-\mathrm{Sr}$ whole rock age of $298 \pm 8 \mathrm{Ma}$ (Rb-Sr whole-rock, CaenVachette et al., 1981) and contain monazite dated at $301 \pm 5 \mathrm{Ma}$ by U-Pb (Mougeot et al., 1997).

The nature of the lower crust underlying these migmatites is documented by xenoliths included in late Variscan plutonic rocks and in Cenozoic basaltic lavas. Biotite-sillimanite enclaves incorporated in diorite intrusive in the southern margin of the Velay dome have recorded P-T conditions of 8 $10 \mathrm{kbar}$ for $700-800^{\circ} \mathrm{C}$ (Montel, 1985). The main mineral paragenesis of felsic and mafic granulites xenoliths in Cenozoic lavas indicate a pressure of $8-10 \mathrm{kbar}$ for a temperature of $700-800{ }^{\circ} \mathrm{C}$ followed by isothermal decompression at 5-6 kbar (Leyreloup, 1974; Downes and Leyreloup, 1986). A few metaigneous xenoliths have preserved relics pointing to a pressure as high as $14 \mathrm{kbar}$ for a temperature of c. $900^{\circ} \mathrm{C}$. These granulites contain zircon grains that yield $\mathrm{U}-\mathrm{Pb}$ ages ranging from 320 to $280 \mathrm{Ma}$ (Downes et al., 1991). The geochemical signatures of the granulites with a metasedimentary protolith indicate a refractory or residual character while the mafic and felsic metaigneous granulites display characteristics of a calcalkaline liquid and of a cumulate, respectively (Dupuy et al., 1979; Downes et al., 1990; Vielzeuf and Vidal, 2012). The representation of the deep part of the cross sections (Fig. 8) is in part based on these characteristics.

\subsubsection{Late Devonian to Carboniferous plutonic rocks}

The c. 70 to $80 \mathrm{Ma}$-long magmatic activity recorded by plutonic and minor volcanic rocks of the French Massif Central is characterized by an extreme variety of petrological types and geochemical signatures. In this section, we describe these petrologic and geochemical characteristics and discuss their significance integrating their spatial distribution and their ages of emplacement (Tab. 3). The petrology and geochemistry of granitoids, as described in the 1/1000 000 geological map of 


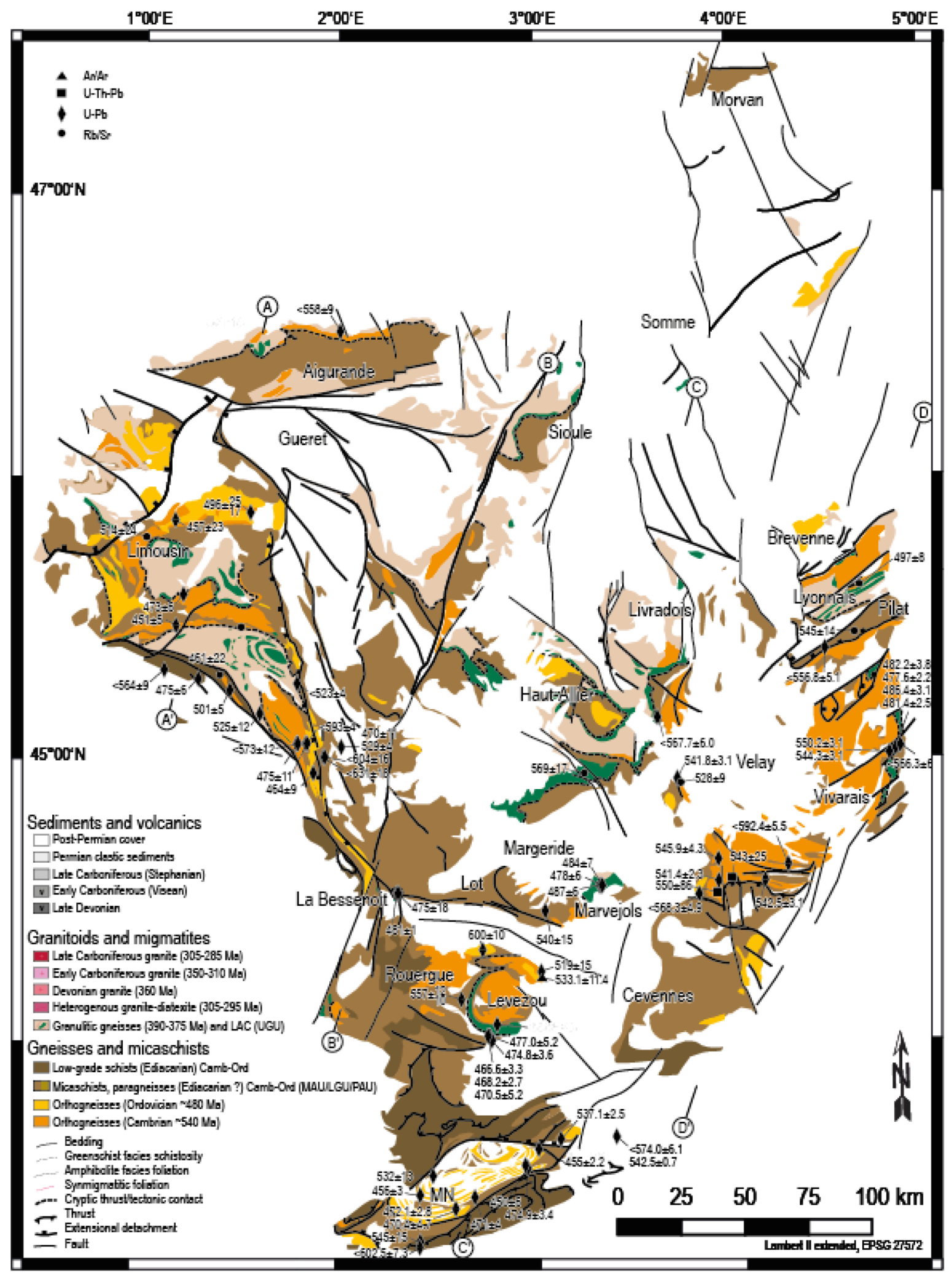

Fig. 5. Geochronological constraints on the emplacement and deposition ages of pre-Variscan rocks. For orthogneisses, the emplacement age corresponds to the $\mathrm{Rb}-\mathrm{Sr}$ whole rock isochron age (circles) or the the youngest $\mathrm{U}-\mathrm{Pb}, \mathrm{U}-\mathrm{Th}-\mathrm{Pb}$ age obtained on magmatic zircon or monazite. For paragneisses, a maximum deposition age is provided by the youngest inherited age. Cambrian and Ordovician orthogneisses do not appear associated with a given nappe but are found throughout the French Massif Central. 
O. Vanderhaeghe et al.: BSGF 2020, 191, 25

Table 2. Geochronological data on Variscan magmatic rocks in the Western part of French Massif Central. $1=$ Boutin and Montigny, 1993; $2=$ Petitpierre and Duthou, 1980; 3 = Rolin et al., 1982; 4 = Gébelin et al., 2007; 5 = Roig et al., 1996; 6= Choukroune et al., 1983; 7 = Berthier et al., 1979; 8= Duthou, 1978; $9=$ Cartannaz et al., 2007a, 2007b; 10 = Cartannaz, 2006; 11 = Bé Mézémé, 2005; $12=$ Ducrot et al., 1983; 13 = Berger et al., 2010a; 14= Duthou, 1978; 15= Rolin et al., 2009; $16=$ Bernard-Griffiths et al., 1977; $17=$ Lafon, 1986; $18=$ Faure et al., 2008; $19=$ Pin and Paquette, 2002; $20=$ Bernard-Griffiths et al., 1985; $21=$ Bertrand et al., 2001; $22=$ Thiéry, 2010; $23=$ Holliger et al., 1986; $24=$ Joly, 2007; 25 = Alexandrov et al., 2000; 26= Lafon and Respaut, 1988; $27=$ Cuney et al., 2002; 28 = Gébelin, 2004; 29= Roig et al., 2002; 30= Monié et al., 2000; 31 = Faure et al., 2009b; 32= Thiéry et al., 2009; 33= Gébelin et al., 2009. B. Geochronological data on Variscan magmatic rocks in the Eastern part of French Massif Central: $34=$ Costa and Maluski, 1988; 35= Costa, 1990; 36= Hottin and Calvez, 1988; 37 = Do Couto et al., 2016; $38=$ Faure et al., 2002; $39=$ Schulz, 2009; $40=$ Pin (unpublished) cited in Duthou et al., 1984; $41=$ Pin and Barbarin (unpublished) cited in Duthou etal., 1984;42 = Saint-Joanis, 1975;43 = Kosztolanyi, 1971;44 = Vialette (unpublished) cited in Duthou et al. $1984 ; 45=$ Laurent et al. , 2017; 46 = Cocherie, 2007; 47 = Gardien et al., 2011;48 = Schulz,2014;49= Couturié et al., 1979; 50 = Respaut, 1984; 51 = Pin, 1979; 52 = Isnard, 1996; 53 = Lafon and Respaut, 1988; $54=$ Pin, 1981;55 = Pin and Lancelot, 1982;56 = Legendre et al., $2009 ; 57=$ Costa, 1989; 58 = Paquette et al., $1995 ; 59=$ Pin, 1981; 60 = Maluski and Monié, 1988; 61 = Duguet, 2003; 62 = Thiéry, 2010; 63 = Delfour and Guerrot, 1997; 64 = Choulet et al., 2012; 65 = Pin and Paquette, 1997; 66= Faure et al.,

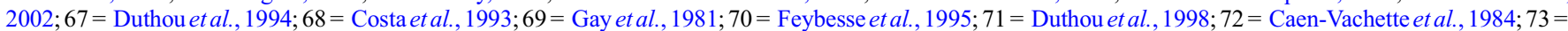
Gourgaud, 1973;74 = Cocherie, 2007; 75 = Bé Mézémé et al.,2006; 76= Mougeot etal., 1997; 77 = Bouilhol et al.,2006; 78= Bé Mézémé,2005; 79= Couzinié et al.,

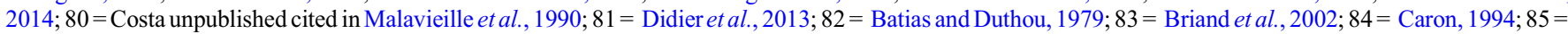
Doublier et al., 2006; 86 = Monié et al., 2000; 87 = Vialette et al., 1979;88 = Brichau et al., 2008; 89 = François, 2009; 90 = Vialette and Sabourdy, 1977;91 = Hamet and Mattauer, 1977; 92 = Mialhe, 1980; $93=$ Chauvet et al., 2012; 94 = Maluski et al., 1991; 95 = Franke et al., 2011; 96= Doublier et al., 2015; $97=$ Whitney et al. 2015;98 = Faure etal.,2014;99= Rogeretal.,2015;100 = Faure etal.,2010;101 = Pitra etal.,2012;102 = Matte etal.,1998; 103= Franke et al.,2011;104= Poilvet et al., 2011.

\begin{tabular}{|c|c|c|c|c|c|}
\hline Region & Location & Rock Type & Method & Age $\pm 2 \sigma(M a)$ & Refs \\
\hline \multicolumn{6}{|c|}{ East Massif Central (wesrtern part) } \\
\hline \multirow{5}{*}{ Couy-Sancerre } & & Amphibolite (LAC) & Ar-Ar Amphibole & $385.5 \pm 8.4 ; 379.4 \pm 8.2$ & 34 \\
\hline & & Bt-grt orthogneiss +/- mylonitic & Ar-Ar Biotite & $390 \pm 7 ; 382.5 \pm 7.6$ & 34 \\
\hline & & Trachy-andesite & Ar-Ar Biotite & $301.6 \pm 6.3$ & 34 \\
\hline & & Greenschist facies mylonite & Ar-Ar Biotite & $317.1 \pm 6.4 ; 336$ & 35,36 \\
\hline & & Lamprophyre dike & Ar-Ar Biotite & $301.5 \pm 6.2 ; 292$ & 35,36 \\
\hline \multirow{14}{*}{ Sioule } & & Kyanite-garnet granulitic paragneiss & U-Th-Pb Mo microprobe,U-Pb Zr SIMS & $416 \pm 15 ; 362 \pm 14 ; 343 \pm 2 ; 328 \pm 2$ & 37 \\
\hline & & Staurotite micaschist & U-Th-Pb Monazite microprobe & $363 \pm 8$ & 37 \\
\hline & & Migmatitic gneiss & U-Th-Pb Monazite microprobe & $363 \pm 4.5$ & 37 \\
\hline & & Biotite-sillimanite gneiss & U-Th-Pb Monazite microprobe & $354 \pm 7$ & 37 \\
\hline & & Sill gneiss & Ar-Ar Mu; Ar-Ar Bio & $332.2 \pm 1.2 ; 331.6 \pm 1.2 ; 334.2 \pm 1.6 ; 333.2 \pm 1.2$ & 38 \\
\hline & & Granite & Ar-Ar Biotite & $336 \pm 1.6 ; 322.3 \pm 1.2$ & 38 \\
\hline & & Orthogneiss (encl. in granite) & Ar-Ar Biotite & $321.4 \pm 1.2$ & 38 \\
\hline & & Mylonite Ste Catherine Fault & Ar-Ar Biotite & $337.6 \pm 1.6$ & 38 \\
\hline & & Gneiss & Ar-Ar Muscovite; Ar-Ar Biotite & $333.3 \pm 1.6 ; 334.6 \pm 1.6$ & 38 \\
\hline & & Micaschist & Ar-Ar Muscovite & $330.8 \pm 1.6$ & 38 \\
\hline & & Staurolite micaschist & Ar-Ar Muscovite & $332.1 \pm 1.6$ & 38 \\
\hline & & Staurolite garnet micaschist & Ar-Ar Muscovite & $328.6 \pm 1.6$ & 38 \\
\hline & & Kyanite Garnet gneiss & U-Th-Pb Monazite microprobe & $337 \pm 9 ; 330 \pm 14$ & 39 \\
\hline & & Sill Bt gneiss & U-Th-Pb Monazite microprobe & $343 \pm 11$ to $328 \pm 15$ & 39 \\
\hline \multirow{12}{*}{ Forez } & L'Hermitage & Granite & Rb-Sr whole rock & $329 \pm 14$ & 41 \\
\hline & Saint-Dier d'Auvergne & Granite & Rb-Sr whole rock & $330 \pm 26$ & 42 \\
\hline & Mayet-de-Montagne & Granite & $\mathrm{Rb}$-Sr whole rock & $318 \pm 15$ & 43 \\
\hline & Bois-Noirs; Charollais & Granite & Rb-Sr whole rock & $346 \pm 8 ; 346 \pm 19$ & 44 \\
\hline & Pierre-qui-Vire & Granite & Rb-Sr whole rock & $323 \pm 4$ & 44 \\
\hline & Mayet-de-Montagne & Granite & Rb-Sr whole rock & $297 \pm 11$ & 44 \\
\hline & Château-Montgilbert & Granite & Rb-Sr whole rock & $282 \pm 8$ & 44 \\
\hline & Bois-Noirs & Granite & U-Pb Zircon ID TIMS & $341 \pm 15$ & 43 \\
\hline & & Bt granite; Porph. Bt granite & U-Pb Zircon LA-ICPMS & $336,9 \pm 1,8 ; 332 \pm 2 \pm 2$ & 45 \\
\hline & & Bt-Am granodiorite; Bt-Am Qz-diorite & U-Pb Zircon LA-ICPMS & $330,1 \pm 1,3 ; 321,2 \pm 1,2$ & 45 \\
\hline & & Bt-Ms Leucogranite & U-Pb Zircon LA-ICPMS & $325,7 \pm 1,3$ & 45 \\
\hline & Gumières & Granite & U-Pb Zircon LA-ICPMS & $313 \pm 2$ & 46 \\
\hline \multirow[t]{4}{*}{ Livradois } & & Porph. Bt-Crd granite; Bt granite & U-Pb Zircon LA-ICPMS & $318,3 \pm 2,6 ; 317.8 \pm 1,3 ; 314,5 \pm 1,7 ; 315.4 \pm 0,9$ & 45 \\
\hline & & Vaugnerite & U-Pb Zircon LA-ICPMS & $309,7 \pm 1,2$ & 45 \\
\hline & & Monzogranite; Granite & U-Pb Zircon LA-ICPMS & $315 \pm 4 ; 311 \pm 18$ & 47 \\
\hline & & Diatexite & U-Th- $\mathrm{Pb}$ Monazite microprobe & $360 \pm 4$ & 47 \\
\hline \multirow[t]{4}{*}{ Haut-Allier } & & Eclogite & U-Pb Zircon TIMS & $432+20-10$ & 12 \\
\hline & & Kyanite Garnet gneiss & U-Th-Pb Monazite microprobe & $337 \pm 9 ; 332 \pm 11$ & 48 \\
\hline & & Garnet Sill Bt mylonite & U-Th-Pb Monazite microprobe & $339 \pm 8$ & 48 \\
\hline & & Staurolite Garnet micaschist & U-Th- $\mathrm{Pb}$ Monazite microprobe & $332 \pm 16$ & 48 \\
\hline \multirow{7}{*}{ Margeride } & Chambon-le-Château & Granite & U-Pb Monazite ID TIMS & $311 \pm 6$ & 52 \\
\hline & Saint-Christophe-d'Allier & Leucogranite & U-Pb Monazite ID TIMS & $305 \pm 14$ & 52 \\
\hline & Grandrieu & Leucogranite & U-Pb Monazite ID TIMS & $305 \pm 4$ & 53 \\
\hline & & Vaugnerite & U-Pb Zircon LA-ICPMS & $313,2 \pm 2,5 ; 309,4 \pm 1,5$ & 45 \\
\hline & & Porph. Bt-Crd granite & U-Pb Zircon LA-ICPMS & $312,9 \pm 2$ & 45 \\
\hline & St-Christophe-d'Allier & Bt-Ms leucogranite & U-Pb Zircon LA-ICPMS & $312,7 \pm 2,3$ & 45 \\
\hline & Grandrieu & Bt-Ms leucogranite & U-Pb Zr LA-ICPMS; U-Pb Mo LA-ICPMS & $311 \pm 1,1 ; 309.3 \pm 1,2$ & 45 \\
\hline \multirow[t]{3}{*}{ Marvejols } & & Orthogneiss & U-Pb Zircon TIMS & $346 \pm 8$ & 54 \\
\hline & & Paragneiss & U-Pb ZrTIMS; U-Pb Mo TIMS & $345 \pm 2 ; 344 \pm 3$ & 51 \\
\hline & & Pegmatite; Amphibolite gneiss & U-Pb Zircon TIMS & $344 \pm 13 ; 340 \pm 4$ & 55 \\
\hline \multirow[t]{4}{*}{ Lot } & & HP trondhjemite & U-Pb Zircon TIMS & $415 \pm 6$ & 55 \\
\hline & & Staurolite-Garnet micaschist & U-Th-Pb Monazite microprobe & $382 \pm 6$ to $370 \pm 6$ & 56 \\
\hline & & Mylonite & Ar-Ar Biotite; Ar-Ar Muscovite & $358.4 \pm 3.6 ; 339.8 \pm 3.5$ & 57 \\
\hline & & Staurolite-Garnet micaschist & Ar-Ar Biotite; Ar-Ar Muscovite & $351.1 \pm 3.5 ; 342.3 \pm 3.5$ & 57 \\
\hline \multirow[t]{8}{*}{ Rouergue } & & Eclogite & U-Pb Zr Pb evapo; Sm-Nd WR & $413 \pm 23 ; 408 \pm 7$ & 58 \\
\hline & Pinet & Granite & U-Pb Zircon & $360 \pm 20$ & 59 \\
\hline & Pinet & Orthogneiss & U-Pb Zircon & $346 \pm 7$ & 60 \\
\hline & Tremouille & Mylonite de granite & Ar-Ar muscovite; Ar-Ar biotite & $343 \pm 2 ; 339 \pm 2$ & 61 \\
\hline & Pinet & Granite & Ar-Ar muscovite/biotite & $342 \pm 2$ & 61 \\
\hline & Savennes & Granite & U-Pb Zircon & $336 \pm 3$ & 62 \\
\hline & & Micaschist & Ar-Ar Mu; Ar-Ar Bio & $337,7 \pm 3,4 ; 333,4 \pm 3,9 ; 343,6 \pm 3,5 ; 297,9 \pm 3,0$ & 35 \\
\hline & & Orthogneiss & Ar-Ar Mus; Ar-Ar Bio & $300,3 \pm 3,1 ; 302,5 \pm 3,2$ & 35 \\
\hline Lévézou & & Metagabbro & U-Pb Zircon TIMS & $367 \pm 10$ & 55 \\
\hline
\end{tabular}


Table 2. (continued)

\begin{tabular}{|c|c|c|}
\hline Region & Location & Rock Type \\
\hline East Massif Cent & ral (eastern part) & \\
\hline Morvan & & Microgranite \\
\hline & & Leucogranite (deformed) \\
\hline & & Leucogranite \\
\hline & & Mylonite \\
\hline Brévenne & & Metarhyolite; Trondhjemite \\
\hline & & Phyllite \\
\hline & & Mylonitic gneiss \\
\hline Lyonnais & & Migmatite \\
\hline & & Retrogressed eclogite \\
\hline & & Orthogneiss \\
\hline & & Synkinematic granite \\
\hline & & Retrogressed granulite \\
\hline & & Synkinematic granite \\
\hline & & Pegmatite in synkinematic granite \\
\hline & Salt-en-Donzy & Bt granite \\
\hline & & Vaugnerite \\
\hline Pilat & & Granite Pilat \\
\hline & Gouffre d'Enfer & Deformed leucogranite \\
\hline & & Granite \\
\hline & & Granite \\
\hline & & Two-mica granite \\
\hline Velay & & Leucogranite \\
\hline & & Migmatite \\
\hline & & Paragneiss \\
\hline & & Velay granite \\
\hline & & Metapelite leucosome \\
\hline & & Micaschist; Paragneiss \\
\hline & & Vaugnerite \\
\hline & & Bt-Amph granodiorite \\
\hline & & Bt-Crd Velay granite \\
\hline & & Granite \\
\hline & & Velay granite \\
\hline & & Late granite \\
\hline & & Mylonite \\
\hline & & Microgranite \\
\hline Vivarais & Saint-Ciergues/Vienne & Granite \\
\hline & Vivarais & Granite \\
\hline & & Vaugnerite \\
\hline & & Porph. Bt granite \\
\hline & & Porph. Bt-granodiorite \\
\hline Cévennes & & Amphibolite \\
\hline & & Micaschist \\
\hline & & Quartzite \\
\hline & & Porph. Bt-Amph granite \\
\hline & & Porph. Bt-granite \\
\hline & & Gneiss \\
\hline & & Stau micaschist; Micaschist \\
\hline & & Quartzite \\
\hline & & Slate; Sity slate \\
\hline & Bougès & Granite \\
\hline & Pt-de-Montvert & Granite \\
\hline & Finiels & Granite \\
\hline & Finiels & Granite \\
\hline & Liron & Granite \\
\hline & St-Guiral & Granite \\
\hline & Aigoual & Granite \\
\hline & Aigoual-St Guiral & Granite \\
\hline & Borne & Granite \\
\hline & Laubies & Adamellite \\
\hline & Finiels & Pegmatite \\
\hline & & Aplite; Aplite-pegmatite \\
\hline & & Granite \\
\hline & & Lode \\
\hline & & Quartz vein \\
\hline Montagne Noire & & Sandstone \\
\hline & & Orthogneiss; Mylonitic orthogneiss \\
\hline & & Paragneiss \\
\hline & & Marble \\
\hline & & Banded gneiss \\
\hline & & Amphibolite \\
\hline & & Staurolite micaschist \\
\hline & & Pegmatite; Pegmatite weakly deformed \\
\hline & & Migmatic orthogneiss \\
\hline & & Granite undeformed \\
\hline & & Silty slate \\
\hline & & Mylonite \\
\hline & & Orthogneiss \\
\hline & & Micaschiste \\
\hline & & Fine-grained meta-aplite \\
\hline & & Slate \\
\hline & & Post-tectonic pegmatite \\
\hline & & Eclogite \\
\hline & & Eclogite \\
\hline & & Orthogneiss \\
\hline & & Migmatite \\
\hline & & Orthogneiss \\
\hline & & Undeformed granite; Gt-granite \\
\hline & & Deformed granite \\
\hline & & Aplite dyke \\
\hline & & Gt-granite \\
\hline & & Deformed granite \\
\hline & & Undeformed granite \\
\hline & & Undeformed Gt-granite \\
\hline & & Synkinematic Gt-granite \\
\hline
\end{tabular}


Table 3. Pressure-Temperature-time data constraining the evolution of metamorphic rocks of the French Massif Central. UGU = Uppper Gneiss Unit, LGU = Lower Gneiss Unit, PAU = Para-autochtonous Unit, EU = Upper Unit, GU/TPU/St SU = Thyviers Payzac- Genis Unit-St Savadour, $\mathrm{PFTB}=$ Paleozoic Fold Thrust Belt (Mt Noire). The pressure is expressed in kbar, the temperature in degrees Celius and the ages are given in Ma. In bold are $\mathrm{U}-\mathrm{Pb}$ on zircon, in italic are $\mathrm{Ar}-\mathrm{Ar}$ ages on micas, underlined ages are whole rock $\mathrm{Rb}-\mathrm{Sr}$ ages and the doubly underlined are $\mathrm{U}-\mathrm{Th}-\mathrm{Pb}$ ages on monazite. $1=$ Costa and Maluski, 1988; $2=$ Burg et al., 1989a, 1989b; $3=$ Boutin and Montigny, 1993; 4= Berger et al., 2010a; 5= Berger et al., 2010b; 6= Santallier, 1981; 7 = Ducrot et al., 1983; 8= Bellot and Roig, 2007; 9= Gébelin, 2004; 10= Costa, 1992; 11= Melleton et al., 2009; $12=$ Lafon, 1986; $13=$ Godard, 1990; $14=$ Audren et al., 1987; 15 = Schulz et al., 2001; 16= Schulz, 2009; 17= Do Couto et al., 2016; 18 = Delor et al., 1986; $19=$ Lotout et al., 2018; $20=$ Faure et al., 2008; $21=$ Delor et al., 1986; $22=$ Joanny et al., 1989; $23=$ Bodinier and Burg, 1981; 24 = Burg et al., 1986; $25=$ Delor et al., 1987; 26 = Burg and Leyreloup, 1989; 27= Costa, 1990; 28= Mercier et al., 1991a, 1991b; 29= Briand et al., 1988; 30= Lardeaux et al., 2001; 31 = Dufour, 1985; 32= Pin and Lancelot, 1982; 33= Costa et al., 1993; $34=$ Gardien, 1990; 35 = Gardien and Lardeaux, 1991; 36 = Gardien, 1993; $37=$ Gardien et al., 2011; 38= Schulz, 2014; 39= Schulz et al., 1996; 40 = Santallier 1981; 41 = Bellot, 2001; 42 = Gébelin et al., 2007; 43 = Caen-Vachette et al., 1984; 44= Vitel, 1988; 45= Briand and Gay, 1978; $46=$ Briand, 1978; $47=$ Burg et al., 1984; $48=$ Costa, 1989; 49= Montel et al., 1992; 50 = Barbey et al., 2015; 51 = Monier, 1980; 52 = Autran and Guillot, 1978; $53=$ Caron, 1994; 54 = Arnaud et al., 2004; 55 = Faure et al., 2010; 56 = Faure et al., 2014; 57 = Roger et al., 2015; 58 = Maluski et al., 1991; 59= Matte et al., 1998; 60= Rabin et al., 2015.

\begin{tabular}{|c|c|c|c|c|c|c|c|c|c|c|c|c|c|c|c|c|c|c|}
\hline & & & \multicolumn{15}{|c|}{ tectonic events } & \multirow[b]{3}{*}{ refs } \\
\hline & & & \multicolumn{3}{|c|}{ HP (oceanic crust) } & \multicolumn{3}{|c|}{ HP (continental crust) } & \multicolumn{3}{|c|}{ Collision } & \multicolumn{6}{|c|}{ Exhumation } & \\
\hline & Locality & Lithology & $P$ & $T$ & age & $p$ & $\mathrm{~T}$ & age & $P$ & $T$ & age & $P$ & $T$ & age & $p$ & $T$ & age & \\
\hline \multirow[t]{27}{*}{ UGU } & \multicolumn{18}{|c|}{ West French Massif Central } \\
\hline & Couy-Sancerre & amphibolite & & & & $11-16.5$ & $500-700$ & $383 \pm 8-385 \pm 8$ & $8-10.5$ & $650-900$ & & $6-7$ & 600 & & & & & 1,2 \\
\hline & Aigurande & amphibolite & & & & & & $381 \pm 5-389 \pm 8$ & & & & & & & & & & 3 \\
\hline & Limousin & Ky-Zo eclogite & $29 \pm 3$ & $660 \pm 65$ & $412 \pm 10$; & & & & & & & $5 \pm 2$ & $670 \pm 35$ & & & & & 4 \\
\hline & Limousin & Ky-Cor-amphibolite & & & & & & & $10 \pm 1$ & $800-820 \pm 36$ & & & & & & & & 5 \\
\hline & Limousin & eclogite & & & $432+20 /-10$ & $15-20$ & $650-750$ & & $11 \pm 1$ & $650-750$ & & 8.5 & $700-750$ & & 8.5 & $W<700$ & & 6,7 \\
\hline & Limousin & metabasite & & & & $17 \pm 1$ & $700 \pm 50$ & & & & & & & & & & & 8 \\
\hline & Limousin & metapelite & 16 & 830 & & $12 \pm 1$ & $750 \pm 50$ & & $7 \pm 1$ & $610 \pm 50$ & $362 \pm 4-352 \pm 7$ & & & & & & & $9,10,11$ \\
\hline & \multirow{2}{*}{\multicolumn{11}{|c|}{\begin{tabular}{|l} 
Limousin/Millemigmatite/granulite \\
East French Massif Central
\end{tabular}}} & & & $334.3 \pm 3.1-309.2 \pm 2.4$ & & & & 12,10 \\
\hline & & & & & & & & & & & & & & & & & & \\
\hline & Morvan & eclogite & & & & $11-16$ & $500-800$ & & & & & $4 \pm 2$ & 700 & & & & & 13 \\
\hline & La Sioule & Gneiss & & & $\underline{416 \pm 15}$ & $9 \pm 1$ & $550 \pm 50$ & & $11.5 \pm 1$ & $760 \pm 50$ & $\underline{363 \pm 5-348 \pm 21}$ & $6 \pm 1$ & $750 \pm 50$ & $\underline{330 \pm 14}$ & $5 \pm 1$ & $650 \pm 50$ & & $14,15,16,17$ \\
\hline & Najac & Glau-eclogite & & & & $11-16$ & $650-730$ & & & & & 7 & $600-650$ & & & & & 18,17 \\
\hline & Najac & eclogite & & & & $15-20$ & $560-630$ & $382.8 \pm 1-376.7 \pm 3.3$ & 11 & 560 & $369 \pm 13$ & & & & & & & 10 \\
\hline & Rouergue & eclogite & & & & $15-20$ & $680-760$ & $408 \pm 6$ & & & & $4-7$ & $550-650$ & & & & & $20,21,22$ \\
\hline & Rouergue & Sta/Ky paragneiss & & & & $11-14$ & $740-860$ & & 9 & 800 & $355.3-348.8 \pm 3,5$ & 3-4 & $520-660$ & & & & & $23,24,22$ \\
\hline & Vibal klippe & metagranodiorite & & & & $10-14$ & $740-860$ & & $8.5-9.5$ & $750-820$ & $347.7 \pm 3.6-353.1 \pm 3.5$ & $3.5-4.5$ & $550-660$ & $338 \pm 3.4$ & & & & $24,25,26,27$ \\
\hline & Artense & eclogite & & & & $>15$ & $700-740$ & & $10-12$ & $720-780$ & & $\mid \begin{array}{c}3.3-4.3 \\
6-7.5\end{array}$ & $650-700$ & & & & & 26,28 \\
\hline & Marvejols & eclogite & & & & $>15.5$ & $690 \pm 40$ & $415 \pm 6$ & $10-12$ & $800-850$ & $363 \pm 2.4-346 \pm 4$ & & & $344 \pm 13$ & & & & $27,28,29$ \\
\hline & Lyonnais & Coe-eclogite & $P>28$ & $700-800$ & & & & & & & & & & & & & & 30 \\
\hline & Lyonnais & eclogite & & & & $16.5-18$ & $700-750$ & & $10-13.5$ & $750-850$ & & $6.5-8.5$ & $650-740$ & $338-337$ & & & & 31 \\
\hline & Lyonnais & Ky/Sill paragneiss & & & & $>10$ & $650-750$ & $\underline{384 \pm 16}$ & $7.5-10.5$ & $750-850$ & $349-345$ & $3.5-4.5$ & 650 & $339-335$ & $<4$ & $500-600$ & & $32,33,34$ \\
\hline & Maclas & Zo Eclogite & & & & $14-16$ & $700-770$ & & $10-13$ & $750-800$ & & $<5$ & $480-575$ & & $<3$ & $300-400$ & & 35 \\
\hline & Tournon & Ky-eclogite & & & & & & & $11-15$ & $650-750$ & & $5-8$ & $500-650$ & & $2.5-5$ & $300-400 \mid$ & & 36 \\
\hline & Livradois & Ky/Sil-Grt paragneiss & & & & & & & $8-10$ & $625-800$ & 360 & $5-6$ & $550-720$ & $315-311$ & $3-4$ & $300-400$ & $307-300$ & 37 \\
\hline & Haut-Allier & eclogite & & & & 20 & $850 \pm 50$ & $432+20 /-10$ & 15 & 800 & & 7.5 & 700 & & 5 & 500 & & 7,38 \\
\hline & Haut-Allier & Sill-Grt gneiss & & & & 8 & 600 & $\begin{array}{l}\geq 384 \\
\geq 384\end{array}$ & $11-13$ & $700-800$ & 360 & \begin{tabular}{|l|}
1.5 \\
$5-10$
\end{tabular} & $700-750$ & $336 \pm 7$ & & & & 29,39 \\
\hline \multirow[t]{14}{*}{ LGU } & West French M. & lassif Central & & & & & & & & & & & & & & & & \\
\hline & $\begin{array}{l}\text { Limousin (Tull } \\
\end{array}$ & geclogite/gneiss & 16 & $700 \pm 50$ & & 9.5 & $825-850$ & & 6 & 650 & $-352 \pm 7,352 \pm 2,357 \pm 4$ & $-365 \pm 5$ & & $332-336,335-337,317 \pm$ & & & & $40,12,9,8,11$ \\
\hline & Limousin & metabasite & & & & 15.6 & 700 & & & & & & & & & & & \\
\hline & Limousin & migmatitic gneiss & & & & $11-12$ & $400-500$ & & $10 \pm 1$ & $600-650$ & $378-374 \pm 5 ; 356 \pm 7$ & $6 \pm 1$ & $700 \pm 20$ & $36-332 ; 337-335 ; 317 \pm$ & $3-4$ & 550 & & $20,8,11$ \\
\hline & Limousin & migmatitic gneiss & & & & & & & & & & $5-6 \pm 1$ & $760-840 \pm 50$ & $316 \pm 2-315 \pm 4$ & & & & $41,8,42,11$ \\
\hline & East French Ma & assif Central & & & & & & & & & & & & & & & & \\
\hline & La Sioule & Gneiss & $3.5 \pm 1$ & $500 \pm 50$ & & $4 \pm 1$ & $650 \pm 50$ & & 9 & 550 & $341 \pm 19-351 \pm 5$ & $7 \pm 1$ & $650 \pm 50$ & $\underline{335-329 \pm 10}$ & $4 \pm 1$ & |600-700 & & $16,39,38,17,11$ \\
\hline & La Sioule & micaschists & & & & & & & $10 \pm 1$ & $600 \pm 50$ & & & & & & & & 16,$39 ; 38,17,11$ \\
\hline & $\begin{array}{l}\text { Lilat } \\
\text { Pile }\end{array}$ & micaschistes & & & & & & & 8 & $570-700$ & & $4-5.5$ & $700-780$ & $322 \pm 9-313$ & $2.5-3$ & $500-550$ & 300 & $\begin{array}{l}\mid 0,3,27,43,44 \\
36,27\end{array}$ \\
\hline & Marvejols & micaschists & & & & 5 & 300 & & 10 & 650 & $351-342 \pm 3.5$ & 7.5 & 700 & & $4-3$ & 550 & & $45,46,47,48$ \\
\hline & Marvejols & metadiorite & & & & & & & & & $351.8 \pm 1.3$ & & & & & & & $\begin{array}{l}35,48,41,2 \\
48\end{array}$ \\
\hline & Vibal klippe & metapelite & & & & & & & $7-8.5$ & $400-450$ & $349.5-351.5 \pm 3.6$ & $5-6.5$ & $550-620$ & & $4.5-5.5$ & 500 & & 24,27 \\
\hline & Haut-Allier & K-Feld/Sil gneiss & $9-12$ & $600-650$ & & $12-15$ & $580-650$ & & $8-12$ & $6010-680$ & & $\begin{array}{c}5-9.5 \\
5-9\end{array}$ & $600-750$ & & $\mid \begin{array}{l}4.5-5.5 \\
2.5-7\end{array}$ & $600-750$ & & 39,38 \\
\hline & Ardèche & migmatitic gneiss & & & & & & & 8 to 10 & $700-800$ & & 5 & 720 & $325-314$ & $7.5 \pm 0$. & $760-850$ & 304 & 49,50 \\
\hline PAU & West French M & lassif Central & & & & & & & & & & & & & & & & \\
\hline & \begin{tabular}{|l} 
Limousin \\
\end{tabular} & metapelites & & & & & & & 9 & 490 & & 5.7 & 520 & & 4.9 & 605 & & $51,15,8$ \\
\hline & Limousin & micashists & & & & & & & 4-9 & $650-750$ & & 9 & 850 & & & & & $52,51,15,8$ \\
\hline & East French $\mathrm{Ma}_{\mathrm{a}}$ & assif Central & & & & & & & & & & & & & & & & \\
\hline & $\begin{array}{l}\text { La Sioule } \\
\end{array}$ & Imicaschists & & & & & & & $7 \pm 1$ & $450 \pm 50$ & $363 \pm 8$ & $8 \pm 1$ & $600 \pm 50$ & $333 \pm 18-327 \pm 12$ & & & & $16,39,38,17$ \\
\hline & Haut-Allier & micaschists & & & & $2,5-5$ & $550-600$ & & $5.5-8$ & $600-650$ & & 7-10 & $650-700$ & & 4-7 & 610-660 & & $16,39,38$ \\
\hline & Cevennes & micaschists & & & & & & & $6-9 \pm 1.3$ & $615-655$ & $343.1 \pm 4.4$ & 4.5 & 500 & & & & & $53,54,55$ \\
\hline MUU & West French M & Jassif Central & & & & & & & & & & & & & & & & \\
\hline & $\begin{array}{ll}\text { GU/TPU/St SU } \\
\end{array}$ & Sta/Grt metapelite & & & & & & & $5-9$ & $570-670$ & $350-360$ & & & & & & & 38,39 \\
\hline & East French Ma & assif Central & & & & & & & & & & & & & & & & \\
\hline & \begin{tabular}{|l|l|l} 
La Sioule \\
\end{tabular} & Micaschistes & & & & & & & $7 \pm 1$ & $450 \pm 50$ & & $8 \pm 1$ & $600 \pm 50$ & & & & & $16,38,39$ \\
\hline & & Metapelite & & & & & & & $7.9 \pm 1.2$ & $641 \pm 32$ & & & & & & & & $16,38,39$ \\
\hline PFTB & East French $\mathrm{Ma}_{\mathrm{a}}$ & assif Central & & & & & & & & & & & & & & & & \\
\hline & Mt Noire & eclogite & & & & 14.5 & $725 \pm 25$ & $359.5 \pm 4.7$ & & & & & & $315.2 \pm 1.6$ & & & & $55 ; 56,57$ \\
\hline & & Migmatitic gneiss & & & & & & & $6.5 \pm 0.5$ & $750 \pm 50$ & $327 \pm 5,324 \pm 3$ & $4 \pm 1$ & $680 \pm 50$ & $316-320$ & & & $308-297$ & \\
\hline & & Micachists & & & & & & & $6.5 \pm 0.5$ & $630 \pm 20$ & & & & & & & & $58,59,60,57$ \\
\hline
\end{tabular}

France (Chantraine et al., 2003) follows the classification by Barbarin (1999). Four types are distinguished (Fig. 6):

- Calc-alkaline granitoids equivalent to the amphibole-rich calc-alkaline granitoids (ACG) of Barbarin (1999) include tonalites, granodiorites and granites. In addition to amphibole, they may contain pyroxene, and frequently include enclaves and small volumes of gabbro to diorites $(i$. $e$. more mafic terms of the same series). They are essentially similar to arc granitoids typically attributed to fractional crystallization of an enriched mafic magma.
- Peraluminous granites and leucogranites correspond to muscovite or muscovite + biotite bearing granites sensustricto equivalent to the muscovite-bearing peraluminous granitoids (MPG) of Barbarin (1999). They are attributed to relatively cold $\left(<850{ }^{\circ} \mathrm{C}\right.$, water present- or muscovite breakdown) melting of metasediments (Gardien et al., 1995; Villaros et al., 2018) and might represent the first melt extracted from the partially molten source at the onset of partial melting.

- Peraluminous granites to granodiorites, corresponding to the cordierite-bearing peraluminous granitoids $(\mathrm{CPG})$ of 
Barbarin (1999). They probably relate to relatively hot ( $\geq 850^{\circ} \mathrm{C}$, biotite breakdown) melting of a continental felsic source (ortho or paragneisses) (Gardien et al., 1995; Barbey et al., 1999; Villaros et al., 2018). They might represent a partially molten source with a high-melt fraction (i.e. diatexites) implying inefficient melt and/or magma extraction but possibly also some solid settling.

- High-K sub-alkaline granitoids, i.e. K-feldspar porphyritic calc-alkaline granitoids (KCG) of Barbarin (1999). They are porphyritic granites to granodiorites, commonly amphibole-bearing, and they typically contain abundant accessory minerals such as apatite and titanite. They contain micro-granular mafic enclaves, and are associated with intermediate plutonic rocks (diorites, to tonalites, to monzodiorites) of similar, "vaugneritic" (see below) composition to which they are probably petrogenetically related (Moyen et al., 2017).

In addition, granites and migmatites are associated with mafic but potassic plutonic rocks locally known as "vaugnerites" (Michon, 1987; Sabatier, 1991). Vaugnerites range from diorites to syenites and consist of amphibole, biotite, clinopyroxene, plagioclase, rare orthopyroxene, interstitial K-feldspar and quartz (Sabatier, 1991). Vaugnerites are K-, LILE- and LREErich mafic to intermediate rocks, pointing to an origin by partial melting of a mantle source enriched by the addition of crustal components, probably during earlier subduction (Rapp et al., 2010; Couzinié et al., 2014, 2016). They form the most mafic components of the KCG suites. Interestingly, they are undistinguishable from CPG and MPG from an isotopic point of view (Sr, Nd or Hf) (Williamson et al., 1992; Couzinié et al., 2016; Moyen et al., 2017).

The study of vaugnerites and their counterparts in other orogenic settings worldwide indicate that their characteristics unlikely result from the crustal contamination of basaltic magma on their way to the surface and are rather primarily inherited from a mantle source enriched by crustal components (Williams, 2004; Laurent et al., 2011, 2014; Prelević et al., 2012; Campbell et al., 2014; Couzinié et al., 2016). It should be mentioned that vaugnerites are similar to the "durbachites" described in other parts of the Variscan belt (Sabatier, 1991; von Raumer et al., 2014). Such rock types are present in most if not all orogenic settings elsewhere in the world where they are called "appinites", "redwitzite", "high Sr-Ba granitoids" (Fowler et al., 2001) or "sanukitoids" in an Archean context (Martin et al., 2005; Heilimo et al., 2010). In the FMC, the isotopic similarity between vaugnerites and crust-derived granites shows that the crustal component was derived from the local crust, probably during (continental) subduction shortly prior to melting (Couzinié et al., 2016; Moyen et al., 2017). A similar model is proposed for the c. 345 Ma old KCG granitoids (the Blatna suite) of the Bohemian Massif (Janousek and Holub, 1997; Janoušek et al., 2004), suggesting that KCG may derive from similar petrogenetic processes as vaugnerites and typically represent their differentiated products. However, this is not so clear for the FMC where KCG may also derive from interactions between vaugnerites and melts derived from the local crust, such as CPG and MPG (Solgadi et al., 2007; Laurent et al., 2017; Moyen et al., 2017). In either case, KCG are genetically linked to the vaugnerites so they are classified together with them in the following as "mantlederived" granitoids.

\subsubsection{Carboniferous volcanic and sedimentary deposits}

In the northern part of the French Massif Central, cystalline rocks are locally capped by middle Carboniferous (Visean: c. 347-325 Ma) volcanic and marine deposits, as exemplified in the Sioule, Morvan and Brévenne regions, implying that they were exhumed and below sea-level at this time (Bertaux et al., 1993; Franke, 2014). In the southern part of the French Massif Central, Devonian to mid-Carboniferous (Visean) carbonates and turbidites are unconformably deposited on plutonic rocks and Ediacaran to Ordovician orthogneisses and paragneisses, in an underfilled foreland basin at the front of a propagating, low-grade fold-and-thrust system (Franke and Engel, 1986; Souquet et al., 2003). Namurian (c. 330-325 Ma) olistoliths and probably Westphalian (c. 325-304 Ma) turbidites and coarse conglomerate deposits attest for the erosion of a growing mountain belt to the north (Engel et al., 1978, 1981; Engel, 1984).

Clastic sediments associated with minor volcanics of late Carboniferous (Stephanian) and Permian ages are unconformably deposited on top of the crystalline rocks in extensional basins associated with strike-slip shear zones marking the waning stages of the Variscan orogeny (Ménard and Molnar, 1988; Van Den Driessche and Brun, 1992; BecqGiraudon, 1993; Becq-Giraudon et al., 1996). Presence of coal in the Stephanian basins attests for a high-geothermal gradient (Copard et al., 2000), which could be attributed to the juxtaposition of the sediments to high-grade rocks freshly exhumed along low-angle detachments. Permian basins are typically wider than Stephanian ones suggesting progressive peneplanation of the Variscan topography at the end of the Carboniferous.

In summary, the superposition of the UGU over the MAU, LGU and PAU define an inverted metamorphic gradient with HP granulite facies migmatites overlying amphibolite facies paragneisses and orthogneisses with locally preserved LT eclogites. The structural, petrological and geochronological record of these nappes document a diachronous history of burial, exhumation and emplacement spreading from the late Silurian to the Devonian. The top of the nappe pile is locally marked by Metamorphic Upper Units (MUU). The lowest structural level is composed of MP to LP migmatites exposed in the Limousin, and in the Velay and Montagne Noire domes. The nappe pile is dissected by strike-slip shear zones and lowangle detachments. It is intruded by plutonic rocks with ages ranging from late Devonian to late Carboniferous-Permian. These crystalline rocks are capped by volcanic and sedimentary rocks deposited in intramontane and foreland basins with ages also ranging from late Devonian to Permian. The detailed structural relationships between these different lithological units and the timing of geological events is further presented in the next section.

\subsection{Architecture and P-T-t record of nappes of the western and eastern French Massif Central}

As stated above, the identification of the LAC as a suture led to the revival, after the pioneer proposition of Demay (1948), of the nappe concept in the French Massif Central and several models have been proposed ever since. The early tectonic model (Burg and Matte, 1978; Matte, 1986) highlights 


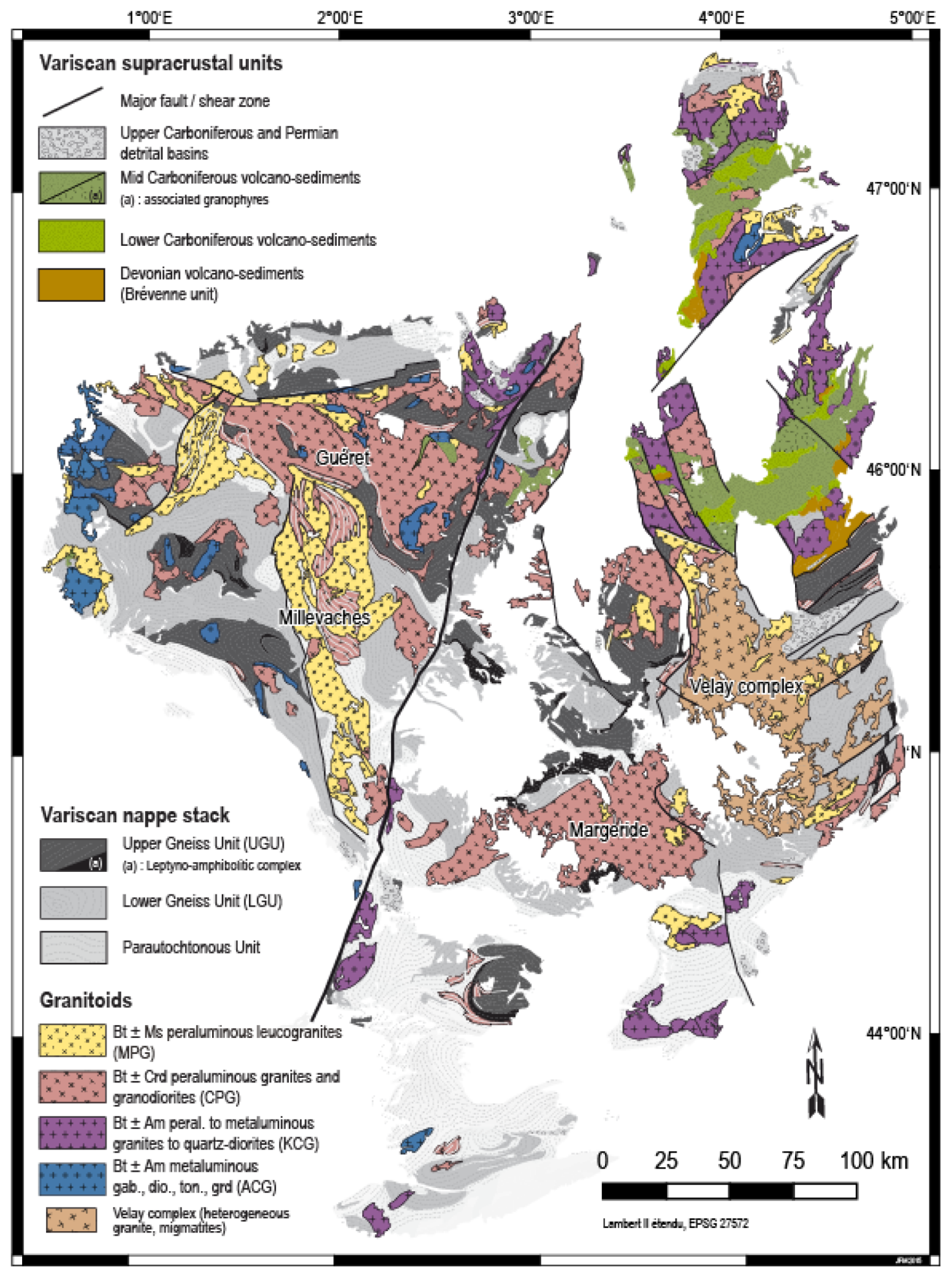

Fig. 6. Petrology of granitoids of the French Massif Central. Plutons are distinguished on the basis of the petrology of their dominant facies according to the classification of Barbarin (1999). ACG-type (calc-alkaline granites) are interpreted as arc magmas originated in an Andean-type continental margin by partial melting of an enriched mantle contaminated by the crust of the upper plate and/or mixed with crutal magmas. MPG-type (or muscovite-bearing peraluminous granites) are attributed to muscovite dehydration- or water present melting of a dominantly metasedimentary source. CPG-type (or cordierite-bearing peraluminous granites) are attributed to biotite dehydration melting of orthogneisses. KCG-type (or K-rich calc-alkaline granites) typically contain abundant micromafic enclaves and are attributed to mixing between magmas generated by partial melting of the crust and a magma generated by partial melting of an enriched lithospheric mantle represented by $\mathrm{Mg}-\mathrm{K}$ diorites (the so-called vaugnerites). 
a. Multiple sutures-nappes model (Burg and Matte, 1978)

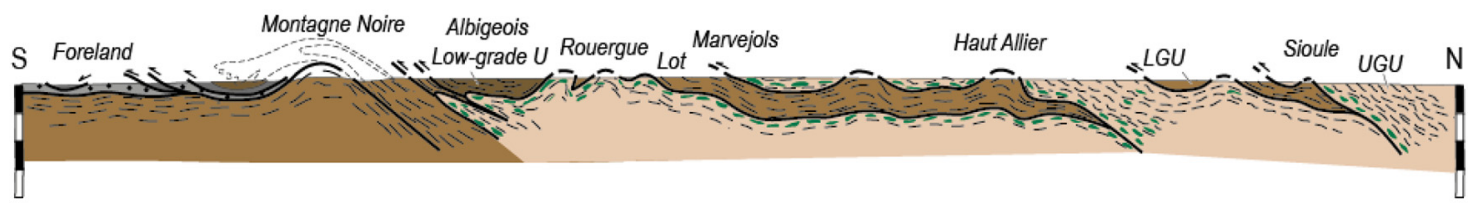

b. Single suture model associated with a basement duplex structure (Matte, 1991)

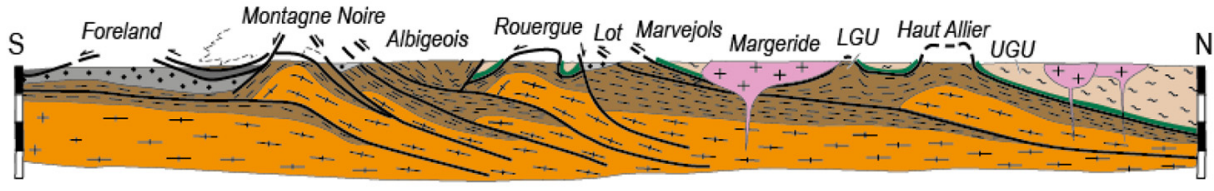

c. Single suture model with a stack of three nappes and an unknown Proterozoic basement (Faure et al., 2009)

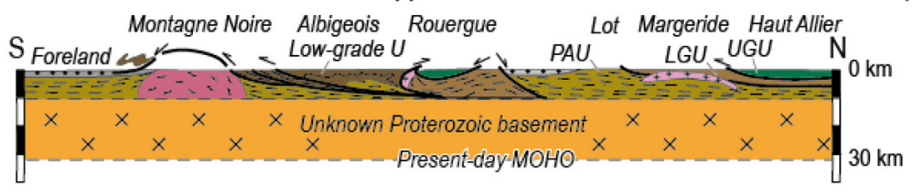

Fig. 7. Cross sections depicting the previously proposed nappe structure. A. Multiple sutures-nappe model (modified after Burg and Matte, 1978). B. Single suture model associated with a basement duplex structure (Matte, 1991). C. Single suture model associated with a stack of three nappes and an "unknown Proterozoic basement" (Faure et al., 2009a, 2009b).

three distinct nappes cored by the migmatites of the UGU; namely from north to south, the Sioule, the Haut Allier Marvejols, and the Rouergue nappes (Fig. 7). In this model each outcropping zone of the UGU and associated LAC corresponds to a locally rooted nappe that, in turn delineates a suture and thus a former oceanic basin. In contrast, subsequent models (Faure et al., 2009a; Matte, 1991, 2001; Lardeaux, 2014) propose that these three nappes form only one with the LAC representing a single ocean rooted beneath the Paris Basin. Consequently, the discontinuous outcrops of the UGU with enclaves of LAC are interpreted as klippes.

The high-grade nappes are characterized by a penetrative composite foliation resulting from superimposed structures and metamorphic parageneses that is typically parallel to the tectonic contacts. This foliation is dominantly shallow dipping (Burg and Matte, 1978; Matte, 1986; Faure et al., 2009a) but is locally steeply dipping such as in the Livradois or in the Monts du Lyonnais (Feybesse et al., 1988; Lardeaux and Dufour, 1987; Gardien et al., 1990, 2011). Away from strike slip shear zones, the lineation associated with this composite foliation is dominantly E-W to WNW-ESE trending in the western part of the French Massif Central and in the Sioule region but is dominantly N-S to NNE-SSW trending in the eastern part (Faure et al., 2009a). Moreover, this foliation is in place affected by regional upright folding such as in the Limousin (Burg and Matte, 1978; Girardeau et al., 1986; Matte, 1986). The structure of the nappe pile is blurred by numerous granitic plutons and original contacts are reworked by thrusts, strikeslip shear zones, low-angle detachments and high-angle normal faults. This complex structural record and the scarcity of outcrops impedes the identification of the original tectonic contacts between the nappes in most places. Nevertheless, in order to discuss the tectonic evolution of potentially distinct nappes, in the following sections, we review available data regarding the structural position and P-T-t record of the lithological-tectonic units presented above distinguishing the
Western and Eastern parts of the French Massif Central separated by the Sillon Houiller Fault (Figs. 8-10).

\subsubsection{Western French Massif Central (W-FMC)}

In the northern part of the W-FMC, the Aigurande region is exposing metamorphic rocks unconformably overlain by Mesozoic sediments of the Paris Basin to the north and is delimited by the La Marche shear zone to the south (Fig. 8 cross section AA'). Metamorphic rocks present a polyphased structural and metamorphic history associated with an inverted metamorphic gradient characterized by the superposition, from top to bottom, of the UGU, the LGU and PAU (Quenardel and Rolin, 1984; Faure et al., 1990). At the top of the nappe pile, the UGU is dominated by diatexites and metatexitic orthogneisses and paragneisses with rare quartzites. These rocks display a dominant garnet-sillimanite-cordierite mineral paragenesis with relics of kyanite that attest for HP partial melting followed by retrogression during decompression. The amphibolite facies foliation of these migmatites is associated with top-to-the SE sense of shear criteria considered to record nappe emplacement (Faure et al., 1990). The boundary between the UGU and the LGU is marked by boudins of eclogitic amphibolites and of ultramafics attributed to the LAC. Amphibolites that are part of the LAC, yield ${ }^{40} \mathrm{Ar}{ }^{39} \mathrm{Ar}$ dates on amphibole at $389 \pm 8 \mathrm{Ma}$ interpreted as the age of amphibolite facies metamorphism (Boutin and Montigny, 1993). A mylonitic shear zone underlines the contact between the migmatitic units of the LGU and micaschists attributed to the PAU (Faure et al., 1990). This contact was first interpreted as a thrust responsible for burial of the PAU beneath the LGU (Quenardel and Rolin, 1984). In contrast, retrogression of the garnet-biotite dominant foliation of the micaschists associated with top-to-the NE kinematic criteria has been reinterpreted as reflecting exhumation of the PAU during a period of regional extension estimated at 325-312 Ma based on syntectonic 

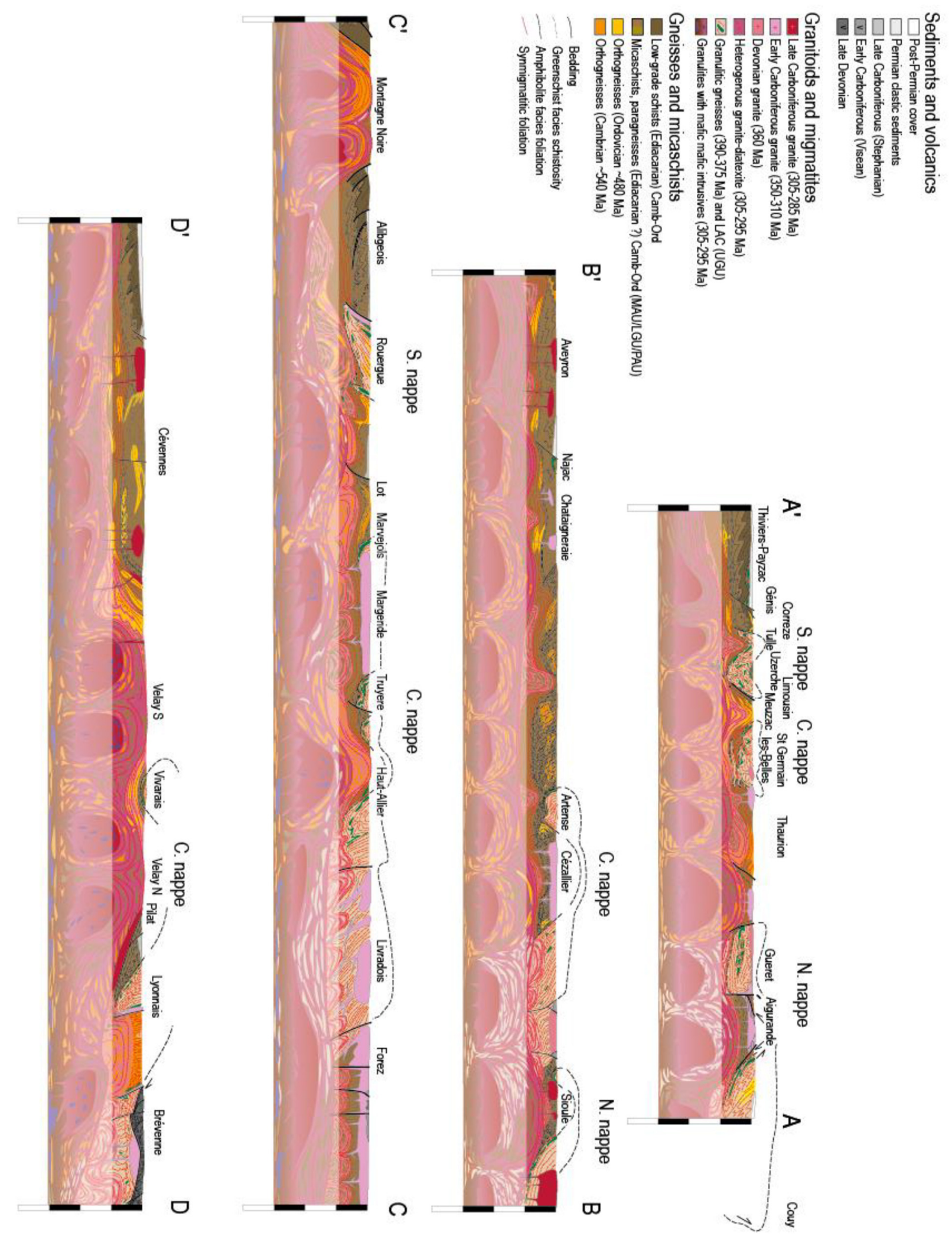

Fig. 8. Cross sections of the French Massif Central. The location of the cross sections (A-A', B-B', C-C', and D-D') is indicated on the geological map Figure 2. Same legend as Figure 3 with the addition of a granulitic lower crust intruded by mantle-derived mafic magmas. The upper part of the sections is constrained by field observations. The shaded lower part of the sections is less constrained and is based on scarce geophysical data that allow the prolongation of some structures at depth and on exposed sections of the Variscan lower crust in the Southern Alps (Ivrea Zone) and in Calabria. 


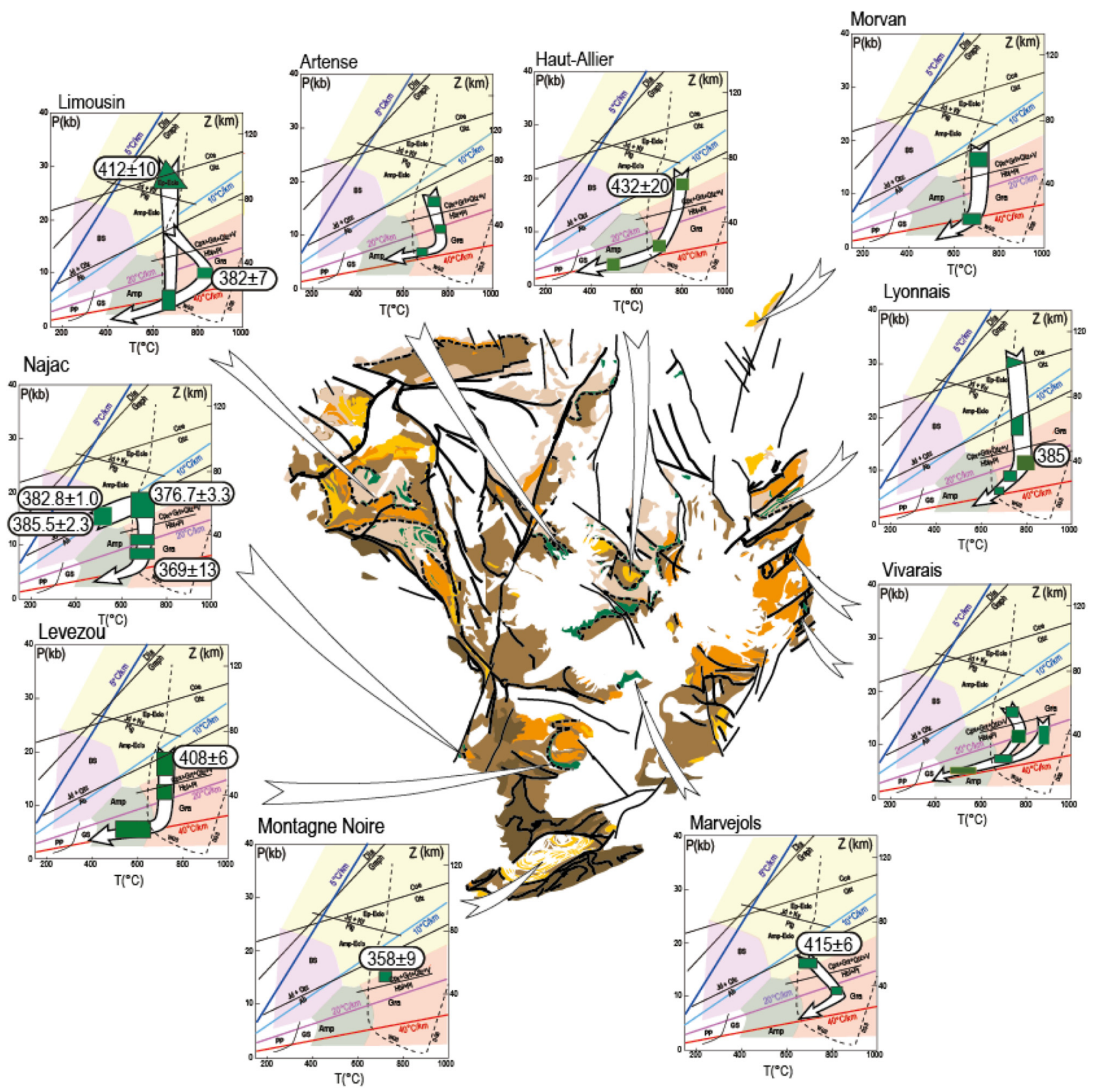

Fig. 9. P-T-t constraints on the metamorphic history of the Upper Gneiss Unit and of the Middle Allochthonous Unit. The LeptyniteAmphibolite Complex is characterized by HT eclogite facies metamorphism retrogressed into granulite facies by isothermal decompression and then into amphibolite facies by a decrease in temperature. Granulite facies to amphibolite facies metamorphism is also recorded in the migmatitic gneisses hosting the LAC. The PT path is depicted by the white arrows and numbers correspond to radiometric ages.

leucogranites emplacement (Faure et al., 1990). It is noteworthy that these micaschists of the PAU contain relics of kyanite and staurolite attesting for a so far undated MP/MT amphibolite facies metamorphism before retrogression into greenschist facies.

To the north of the FMC, the crystalline basement beneath the Paris Basin has been sampled in the Couy deep borehole down to $3500 \mathrm{~m}$ (Fig. 1). Granulite facies migmatites of the UGU are associated with metabasites attributed to the LAC with a Cambrian-Ordovician protolith as constrained by a
Sm-Nd isochron of $494 \pm 17 \mathrm{Ma}$ and a U-Pb zircon date of $497 \pm 13 \mathrm{Ma}$ (Pagel et al., 1992). These rocks display a NE-SW trending foliation steeply dipping to the SE. The granulite facies mineral paragenesis yield a pressure ranging from 15 to $9 \mathrm{kbar}$ and a temperature from 900 to $650^{\circ} \mathrm{C}$. Retrogression into the amphibolite facies is recorded at c. $6 \mathrm{kbar}$ for c. $600^{\circ} \mathrm{C}$ (Burg et al., 1989a, 1989b; Ballèvre and Balé, 1992). Amphibolites yield an $\mathrm{Rb}-\mathrm{Sr}$ isochron of $387 \pm 2 \mathrm{Ma}$ interpreted as dating high-grade metamorphism. ${ }^{40} \mathrm{Ar} /{ }^{39} \mathrm{Ar}$ ages on amphibole and biotite from granulite facies amphibolites and 


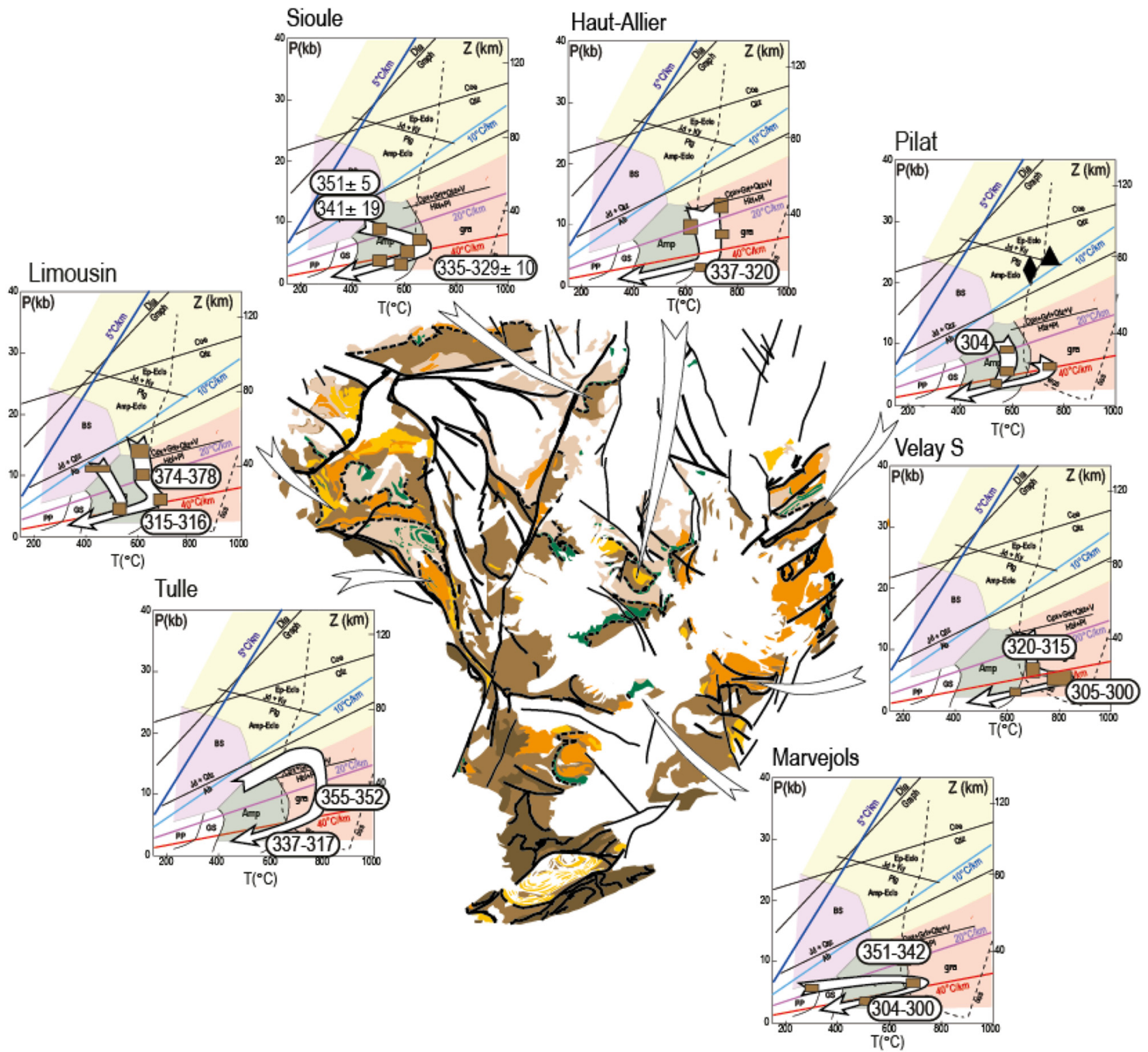

Fig. 10. P-T-t constraints on the metamorphic history of the Lower Gneiss Unit. The P-T-t paths of orthogneisses and paragneisses of the LGU indicate first an increase in temperature followed by isobaric cooling. This is particularly well illustrated by the P-T-t path of the south Velay which is characterized by a HT/LP gradient. The PT path is depicted by the white arrows and numbers correspond to radiometric ages.

orthogneisses, respectively range from c. $385 \mathrm{Ma}$ to c. $379 \mathrm{Ma}$ and point to rapid cooling below $300{ }^{\circ} \mathrm{C}$ before the end of the Devonian (Costa and Maluski, 1988). Accordingly, the P-T-t record of the UGU sampled in the Couy deep borehole is similar to the one of the UGU exposed in the Aigurande region and these rocks are attributed to the same nappe that will be designated as the northern nappe in the following.

South of the Aigurande region, the northern Limousin region exposes a slightly different nappe package. The UGU is mainly made of migmatitic paragneisses with ubiquitous relics of HP metamorphism expressed as eclogites and numerous garnet amphibolite boudins (Le Breton et al., 1986). Below, the LGU exposed in the core of the Thaurion and Meuzac antiforms (Fig. 8, section AA') is dominated by amphibolite facies orthogneisses with some paragneisses. In addition to the high-grade units recognized in the Aigurande region, several authors have identified a Middle Allochthonous Unit (MAU) stacked in between the UGU and LGU (Girardeau et al., 1986; Dubuisson et al., 1989; Berger et al., 2010a, 2010b). The UGU contains eclogite facies metabasites attributed to the LAC yielding $\mathrm{U}-\mathrm{Pb}$ zircon ages pointing to a crystallization of their protolith between c. 489 and c. $475 \mathrm{Ma}$. The eclogitic UHP event is dated at $412 \pm 10 \mathrm{Ma}$ followed by a resetting potentially linked to partial melting and retrogression into the granulite facies at $382 \pm 7 \mathrm{Ma}$ (Berger et al., 2010a), which is also consistent with previous whole rock $\mathrm{Rb}-\mathrm{Sr}$ isochrons from c. 385 to c. $375 \mathrm{Ma}$ (Duthou, 1978; Duthou et al., 1994), $\mathrm{U}-\mathrm{Pb}$ on zircon at $383 \pm 5 \mathrm{Ma}$ (Lafon, 1986) and U-Th-Pb on monazite between c. 378 and c. $374 \mathrm{Ma}$ (Faure et al., 2008). The relationship between this nappe pile and the one exposed 
in the Aigurande region is not clearly identified but the differences displayed by their cooling histories point to distinct exhumation histories. In the following, the nappe exposed in the northern Limousin will be designated as the Central nappe.

In the southern Limousin the nappe pile is deformed in a serie of upright folds designated as the Uzerche synform and the Tulle antiform (Ledru et al., 1989) (Fig. 8, section AA'). The UGU is dominated by granulite facies migmatitic paragneisses with eclogitic mafic boudins yielding peak metamorphic conditions at c. $15 \mathrm{kbar}$ and c. $750^{\circ} \mathrm{C}$ (Santallier, 1981; Bellot and Roig, 2007). In a lower structural position, migmatitic paragneiss and orthogneiss that contain boudins/ enclaves of eclogites and garnet-spinel peridotites with peak P$\mathrm{T}$ conditions at c. $15 \mathrm{kbar}$ and c. $700^{\circ} \mathrm{C}$ similar to the ones of the UGU (Santallier, 1981; Ledru et al., 1989; Bellot and Roig, 2007). These eclogitic boudins have been first attributed to the LGU but could be part of the MAU according to their structural position and P-T record. Structurally below these rocks, migmatitic paragneisses display a syn-migmatitic foliation underlined by cordierite-sillimanite-bearing leucosomes that document a retrograde P-T path from c. $9.5 \mathrm{kbar}$ at c. $850{ }^{\circ} \mathrm{C}$ to c. $6 \mathrm{kbar}$ at c. $600{ }^{\circ} \mathrm{C}$ and locally to c. $3.5 \mathrm{kbar}$ at c. $550^{\circ} \mathrm{C}$ (Bellot and Roig, 2007). These migmatites yield a U-Pb age on zircon at $382 \pm 5 \mathrm{Ma}$ interpreted as the age of partial melting (Lafon, 1986) and a variety of ${ }^{40} \mathrm{Ar} /{ }^{39} \mathrm{Ar}$ ages on micas as well as $\mathrm{U}-\mathrm{Th}-\mathrm{Pb}$ ages on monazite spreading from c. $350 \mathrm{Ma}$ to c. $315 \mathrm{Ma}$ that might reflect progressive exhumation and cooling, or partial reseting owing to recrystallization, during the Carboniferous (Costa, 1992; Gebelin et al., 2004; Melleton et al., 2009). The high-grade nappes are overlain by the Thiviers-Payzac Unit and by the Génis Unit (Guillot and Doubinger, 1971; Guillot and Lefevre, 1975; Santallier, 1981; Bellot and Roig, 2007) that are affected by a prograde Barrovian metamorphic gradient with peak conditions at c. $9 \mathrm{kbar}$ for $\mathrm{c} .750{ }^{\circ} \mathrm{C}$ at the lowest structural level. The Thiviers-Payzac Unit is intruded by pre-tectonic calc-alkaline dolerite dykes dated at $363 \pm 10$ Ma by K-Ar on whole rock (Bellot and Roig, 2007). The presence of high-grade rocks of the UGU sandwiched in between lower-grade rocks is interpreted to correspond to vertical extrusion of the highpressure UGU into an orogenic wedge affected by Barrovian metamorphism (Bellot and Roig, 2007), as envisioned in models of Chemenda et al. (1996) or Escher and Beaumont (1997). According to these data, the South Limousin UGU is characterized by a younger cooling history than the North Limousin one, which is used to define what will be referred as the southern nappe in the following.

The oldest Variscan plutonic rocks identified in the Western part of the French Massif Central are late Devonian and display a variety of petrological and geochemical signatures. Small plutons emplaced into the UGU (ACG type of Barbarin 1999), with a composition ranging from gabbro to granodiorite and signatures from calc-alkaline to tholeiitic, define a broadly linear trend referred to as the "Limousin tonalite line" (Peiffer, 1986; Cuney et al., 1990, 1993). These rocks first yielded TIMS U-Pb zircon ages of $379 \pm 19 \mathrm{Ma}$ and $355 \pm 2 \mathrm{Ma}$ (Bernard-Griffiths et al., 1985) and have since provided more precise ages of $365 \pm 3 \mathrm{Ma}$ and $360 \pm 1 \mathrm{Ma}$ by the same method (Pin and Paquette, 2002). In contrast, the contemporaneous Guéret pluton (Turpin et al., 1990) is a cordierite-bearing peraluminous granite $(\mathrm{CPG}$ in the nomenclature of Barbarin, 1999) dated in the late Devonian (Berthier et al., 1979). It forms a c. $1 \mathrm{~km}$ thick laccolith overlying the cordierite-bearing migmatitic gneisses of the UGU (Lameyre et al., 1988; Dupis et al., 1990; Gébelin et al., 2006). These plutonic rocks are cross-cut by a system of E-W to NW-SE trending dextral shear zones including the La Marche, Courtine and Pradines shear zones that started their activity at about $350 \mathrm{Ma}$ as attested by ${ }^{40} \mathrm{Ar} /{ }^{39} \mathrm{Ar}$ on syntectonic biotite in the Aigurande plateau (Gébelin et al., 2007). These shear zones control the syntectonic emplacement of CPG and MPG plutons from 345 to $310 \mathrm{Ma}$ (Lafon and Respaut, 1988; Lerouge and Quenardel, 1988; Alexandrov et al., 2001; Gébelin et al., 2007, 2009; Rolin et al., 2009, 2014), bounded at their roof by detachment zones (Faure and Pons, 1991; Gébelin et al., 2007).

Leucogranites are interpreted to be generated by partial melting of a metasedimentary middle crust (Cuney et al., 1990; Williamson et al., 1996; Moyen et al., 2017; Villaros et al., 2018). This is consistent with their structural position relative to their host rocks, as exemplified by the Millevaches laccolith rooted into cordierite-bearing migmatitic paragneisses that have been affected by partial melting under MP/MT amphibolite facies conditions $\left(6 \mathrm{kbar}\right.$ for $\left.850{ }^{\circ} \mathrm{C}\right)$ as attested by leucosomes localized in strike-slip shear bands (Gébelin, 2004; Gébelin et al., 2006, 2009). This high-grade metamorphism and partial melting has been dated at $315 \pm 4 \mathrm{Ma}$ and $316 \pm 2 \mathrm{Ma}$, coeval with the syntectonic emplacement of leucogranites in the Pradines dextral strike-slip shear zone at $313 \pm 4 \mathrm{Ma}$ (Gébelin et al., 2009). The dextral strike-slip shear zones are cross-cut by high-angle normal faults and low-angle detachments such as the NE-SW trending Nantiat and Bussière shear zones and the N-S trending Argentat shear zone (Fig. 3) (Gébelin et al., 2007, 2009). The footwall of these detachment zones represented sites of strong (meteoric) fluid-rockdeformation interactions during the late Carboniferous (Dusséaux, 2019; Dusséaux et al., 2019). Exhumation along these low-angle mylonite zones is constrainted to be middle (Visean) to late Carboniferous (Stephanian) in age, by argon thermochronology (Alexandrov et al., 2000; Roig et al., 2002; Gébelin, 2004; Gébelin et al., 2007; Rolin et al., 2014). The activity of these shallow dipping detachments and strike-slip shear zones, which are part of the Sillon Houiller Fault, controlled the deposition of late Carboniferous coal-bearing sediments in small extensional and pull-apart basins (Feybesse, 1981; Thiéry et al., 2009). The onset of deposition in these basins during the Visean is confirmed by a fireclay dated at $332 \pm 4 \mathrm{Ma}$ by U-Pb TIMS on zircon in northern Limousin (Bruguier et al., 1998). The Permian clastic sedimentary deposits of the Brive basin unconformably overlie these late Carboniferous deposits and mark the end of the Variscan tectonic activity in this region.

Although scarce, available geophysical data for the W-FMC provide some constraints on the deep crustal structure. Gravity data indicate that most plutons are laccoliths with an average thickness of about $1 \mathrm{~km}$ but that can locally reach up to $3 \mathrm{~km}$ (Gébelin et al., 2006; Joly et al., 2008, 2009). As a complement, seismic data allow to identifiy the prolongation of surface structures at depth (Bitri et al., 1999). In the upper crust, the main feature is that most reflectors appear to match the projection of the dominantly shallow-dipping highgrade fabric parallel to lithological-tectonic contacts identified at 
the surface. These reflectors are only crosscut and offset by highangle faults and low-angle detachments. For example, highangle faults separating the North and South Limousin and affecting high-grade rocks coring the Meuzac antiform, are offsetting reflectors marking the contacts between the UGU, MAU, LGU and PAU and are rooted into a high reflectivity zone at $10 \mathrm{~km}$ depth. Similarly, the Argentat shear zone corresponds to a several $\mathrm{km}$ thick zone of reflectors shallowly dipping to the West rooting into a reflective zone at about $10 \mathrm{~km}$ depth. Accordingly, the Argentat shear zone might be interpreted as the breakaway zone of a low-angle detachment rooted in the brittleductile transition. These high reflectivity zones are overlying a c. $10 \mathrm{~km}$ thick seismically transparent middle crustal zone with a relative low density that has been interpreted to be composed of granitic material (Bitri et al., 1999). Alternatively, this middle crust, coring low amplitude (few $\mathrm{km}$ ) and long wavelength (tens of $\mathrm{km}$ ) dome-shaped structures, could be composed by migmatites, as it has been proposed for similar structures detected beneath low-angle detachments in the South Armorican Massif (Bitri et al., 2010). Beneath this transparent middle crustal zone, the lower crust is typically marked by its high reflectivity from c. $20 \mathrm{~km}$ down to the Moho at c. $30 \mathrm{~km}$ depth (Bitri et al., 1999). These characteristics are used to constrain the deep part of the cross sections (Fig. 8) beyond information provided by surface outcrops.

\subsubsection{Eastern French Massif Central (E-FMC)}

The continuity of the nappes from the W-FMC to the E-FMC across the Sillon Houiller Fault is not easily established. Nevertheless, as for the W-FMC, the P-T-t record of high-grade rocks of the E-FMC points to the diachronous emplacement of several distinct nappes.

In the northern part of the E-FMC, the position of the late Devonian Brévenne back-arc, to the south of the Morvan arc represented by the late Devonian Somme Unit, has been used to infer a southward subduction of the Rheic Ocean along a continental active margin (Faure et al., 1997, 2008). Sparse outcrops of retrogressed eclogites, serpentinised peridotites and amphibolites affected by HP metamorphism are characteristic of the UGU (Gardien et al., 1988; Godard, 1990). The timing of exhumation of these high-grade rocks and their structural relationships with the Devonian volcanic-sedimentary sequences are ill-defined. However, it has been proposed that they were already exhumed before the middle Devonian at the time of formation of the Morvan arc and Brévenne back-arc (Faure et al., 1997, 2008). In that case, the UGU exposed in the Morvan region might correspond to the northern nappe described in the W-FMC. Because of these uncertainties, this part of the French Massif Central is not represented on cross sections of Figure 8.

In the Sioule area (Fig. 8, section BB'), the Variscan basement shows a dominant shallow-dipping composite foliation deformed in a broad antiform cored by granitic plutons and displaying an inverted metamorphic gradient (Faure et al., 1993, 2002). The top of the nappe pile is made of cordieritebearing diatexites and migmatitic orthogneisses and paragneisses that have recorded isothermal decompression from $12-13 \mathrm{kbar}$ to $2-3 \mathrm{kbar}$ at $650-700^{\circ} \mathrm{C}$. Both lithologies display a composite foliation bearing a NE-SW trending lineation (Audren et al., 1987; Schulz et al., 2001; Schulz, 2009). Serpentinite boudins and granulitic relics allow to assign these rocks to the UGU (Ravier and Chenevoy, 1979). Metamorphic monazite with a U-Th-Pb EPMA age at $416 \pm 15 \mathrm{Ma}$ is attributed to HP metamorphism (Do Couto et al., 2016) but retrogression under amphibolite facies has not been dated. The contact with the lower-grade underlying micaschists attributed to the PAU has first been interpreted as a thrust (Burg and Matte, 1978; Ledru et al., 1989) but has been then attributed to an extensional detachment reflecting exhumation of the PAU during Visean regional extension dated at 337-336 Ma by Ar thermochronology on mica and amphibole of syntectonic granites (Faure et al., 1993, 2002). Despite uncertainties on the timing of exhumation of the UGU in the Morvan and Sioule regions, we propose to consider that they are part of the same northern nappe exhumed, at least partly, during the late Devonian as previously proposed by Faure et al. (Faure et al., 1997, 2008). The southern boundary of the Sioule-Morvan high-grade nappe is marked by a dextral strike-slip corridor (Hermitage shear zone) crossing the Forez and Brévenne regions and localizing the emplacement of syntectonic MPG plutons dated from $332 \pm 2$ to $326 \pm 2 \mathrm{Ma}$ (U-Pb on zircon, Laurent et al., 2017). These high-grade metamorphic and plutonic rocks are capped by Visean undeformed volcanics, volcaniclastics and granophyres represented by the "tufs anthracifères" series dated at $336 \pm 5 \mathrm{Ma}$ by a $\mathrm{Rb}-\mathrm{Sr}$ isochron (Carrat and Zimmermann, 1984; Sider and Ohnenstetter, 1986; Delfour et al., 1989; Leloix et al., 1999; Faure et al., 2002). A similar age of $332 \pm 2 \mathrm{Ma}$ has been obtained by U-Pb TIMS on zircon from a rhyolite sampled in the Decazeville basin (Bruguier et al., 1998). These Visean volcanic rocks are locally associated with marine deposits, which has been used to propose that the high-grade rocks of the nappe pile were exhumed but remained below sea-level at this time (Franke, 2014).

South of the Hermitage shear zone, several fragments of the UGU, composed of migmatitic paragneisses and orthogneisses grading from metatexites to diatexites, are exposed in the Combrailles, Cézallier, Artense, Livradois, Truyère, HautAllier, Lyonnais and Vivarais regions (Feybesse et al., 1988; Lardeaux and Dufour, 1987; Gardien, 1993; Gardien and Lardeaux, 1991; Mercier et al., 1991a, 1991b; Gardien et al., 2011) (Fig. 8, sections BB', CC', DD'). We propose here that these litho-tectonic units are part of the central nappe. The migmatitic gneisses of the UGU yield whole rock $\mathrm{Rb}-\mathrm{Sr}$ isochrons ranging from 385 to $375 \mathrm{Ma}$ in the Lyonnais (Duthou et al., 1981, 1994) and monazite age of $360 \pm 4 \mathrm{Ma}$ by U-Th$\mathrm{Pb}$ EMPA in the Livradois (Gardien et al., 2011; Vanderhaeghe et al., 2013). These ages are tentatively interpreted to record the transition from an early stage of HP granulite facies (at least $10 \mathrm{kbar}$ for $\mathrm{c} .800^{\circ} \mathrm{C}$ ) followed by decompression to $6 \mathrm{kbar}$. In the northern root zone of this nappe, exposed in the Lyonnais and Livradois, the NE-SW trending regional foliation of the UGU migmatites is steeply dipping to the north (Lardeaux and Dufour, 1987; Feybesse et al., 1988; Gardien et al., 1990, 2011) (Fig. 8, sections CC', DD'). North of the Livradois, these migmatites display a penetrative $\mathrm{C} / \mathrm{S}$ fabric consistent with a top to the south sense of shear (Koné, 1985; Gardien et al., 2011; Vanderhaeghe et al., 2013). To the north of the Lyonnais, the late Devonian volcanic-sedimentary series of the Brévenne unit are characterized by upright folds with an NNE-SSW trending axial planar schistosity under greenschist facies metamorphism (Fig. 8 section DD'). The contact between the Brévenne Unit and the UGU of the Lyonnais is marked by transposition of previous structures into 


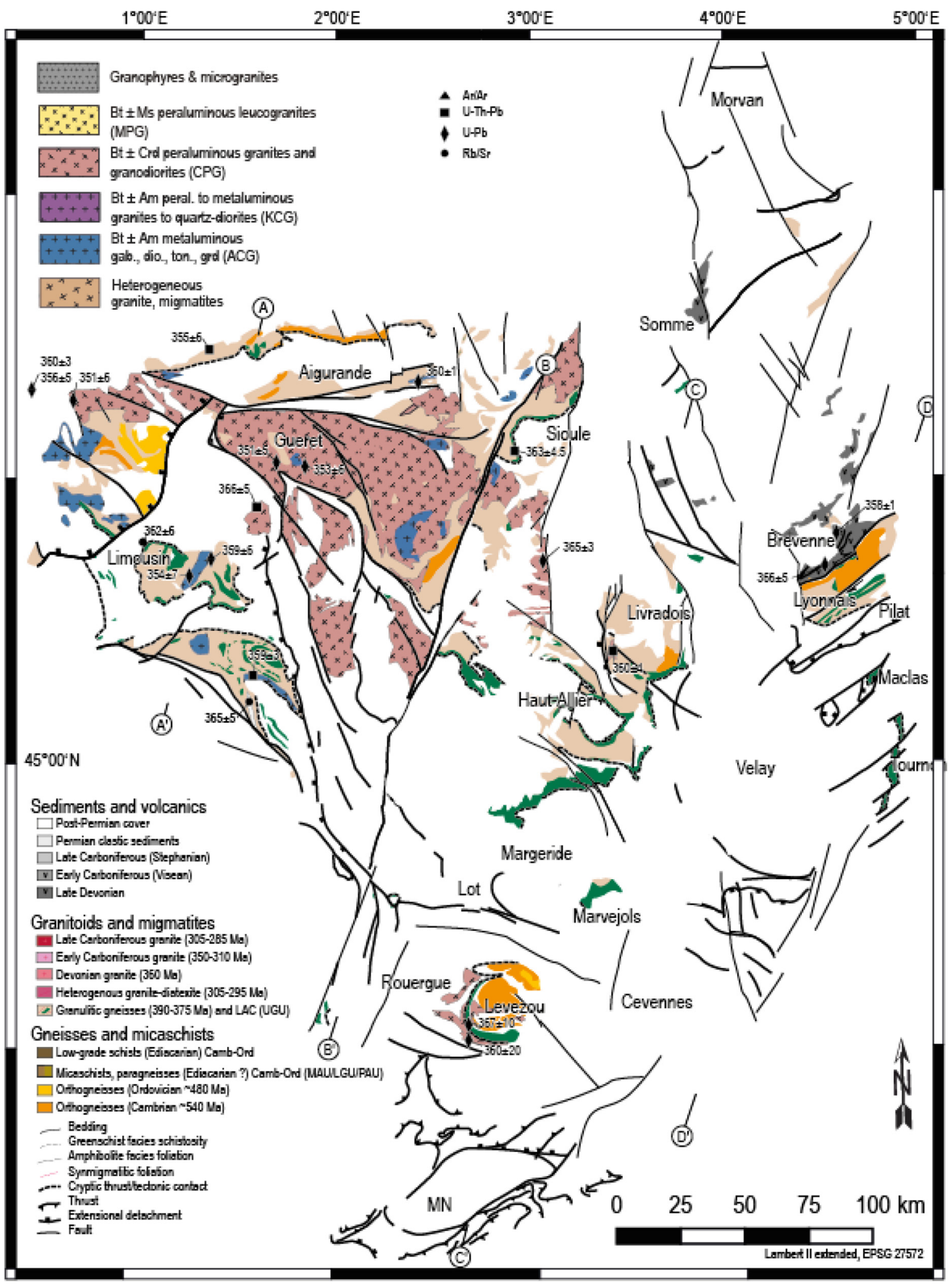

Fig. 11. Late Devonian to Early Carboniferous magmatism. The western part of the French Massif Central is dominated by plutonic rocks of the ACG-type and CPG-type while the eastern part of the French Massif Central also comprises volcanics with a tholeiitic to calc-alkaline signature. 


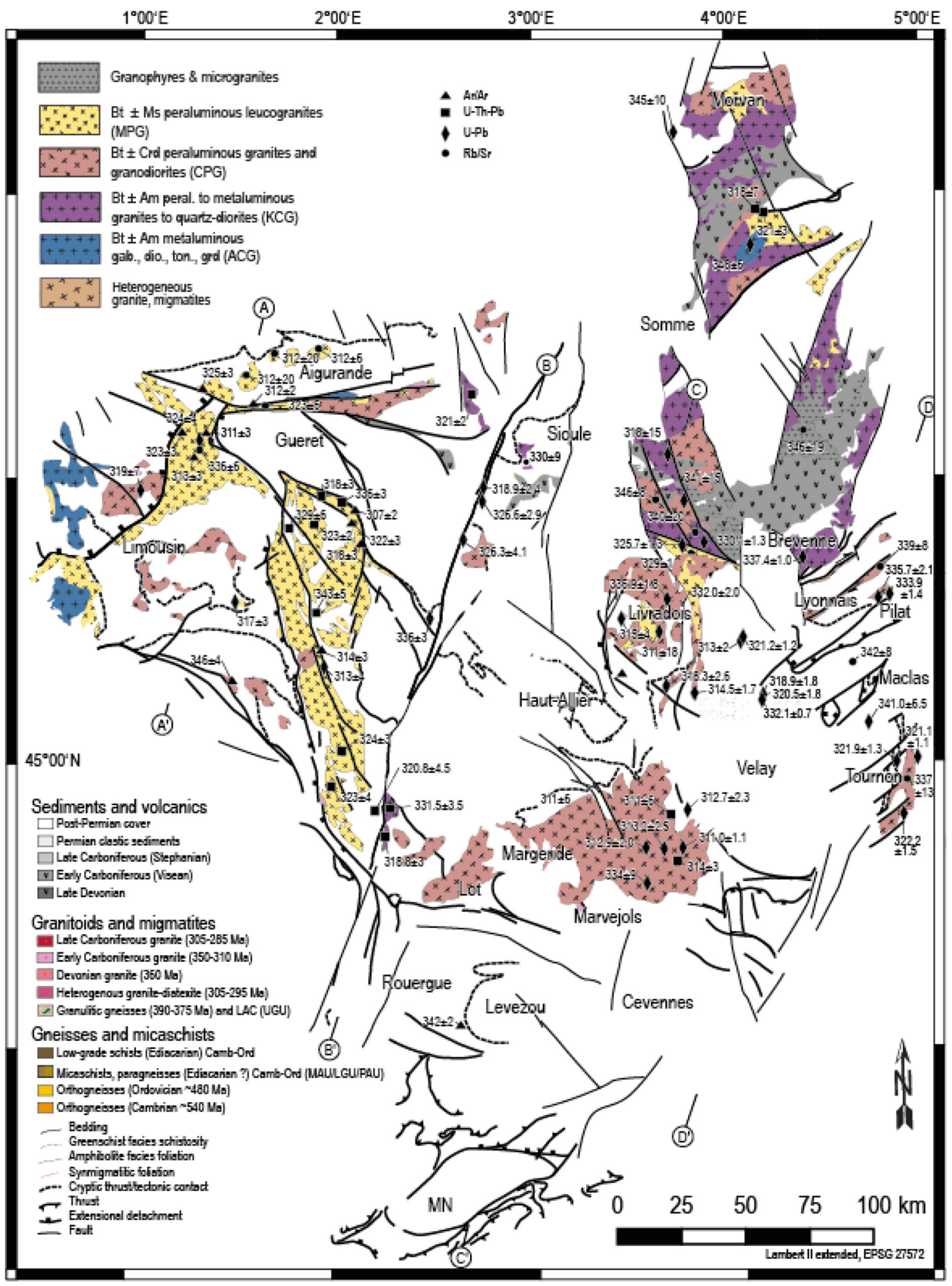

Fig. 12. Middle Carboniferous magmatism. Magmatic rocks with ages ranging from c. 345 to c. 310 Ma are widespread throughout the northern part of the French Massif Central indicating the presence of a partially molten source at depth during this period. Plutonic rocks display a variety of geochemical signatures encompassing MPG-type, CPG-type, and KCG-type pointing to the contribution of crustal and mantle sources. 
(a)
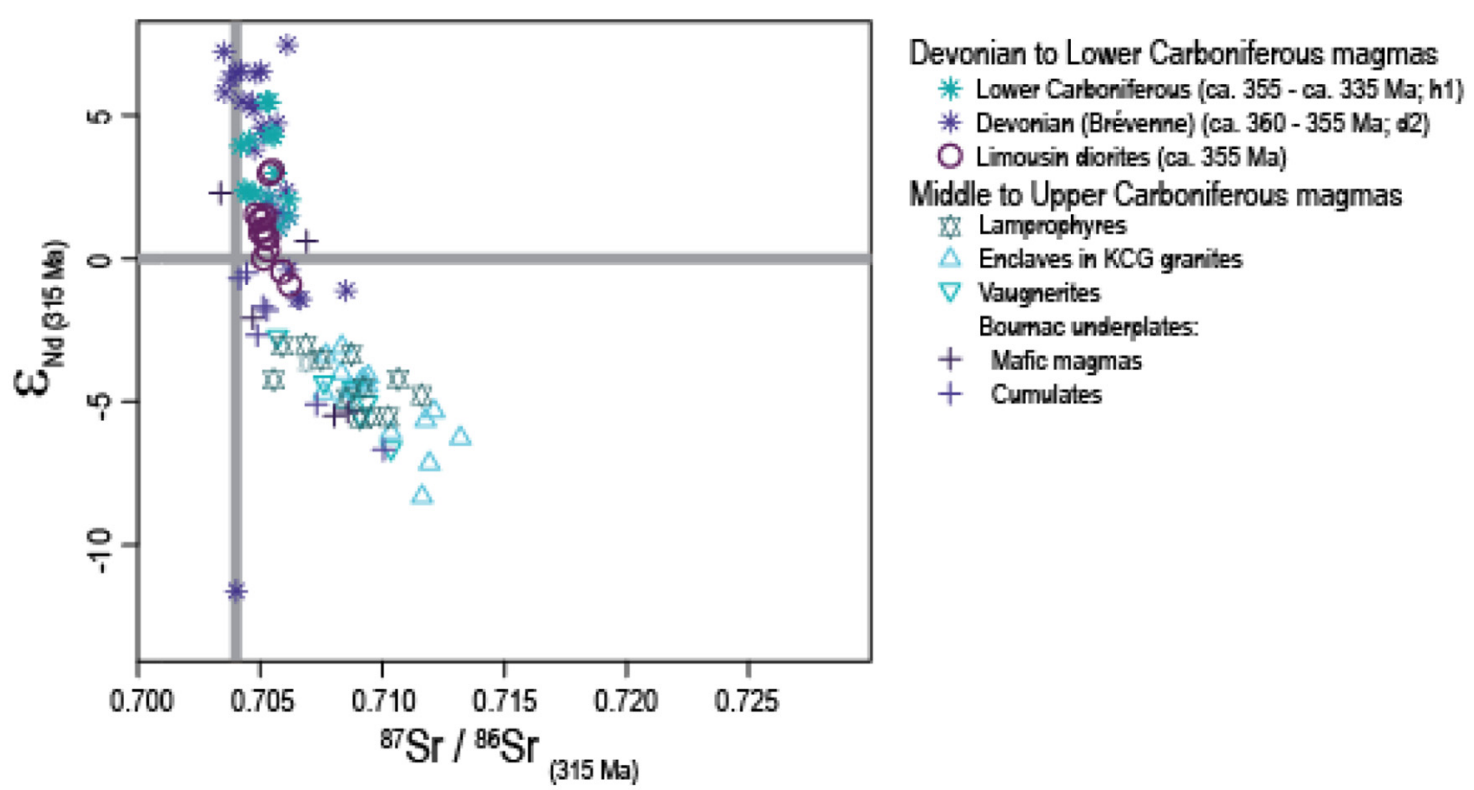

(b)
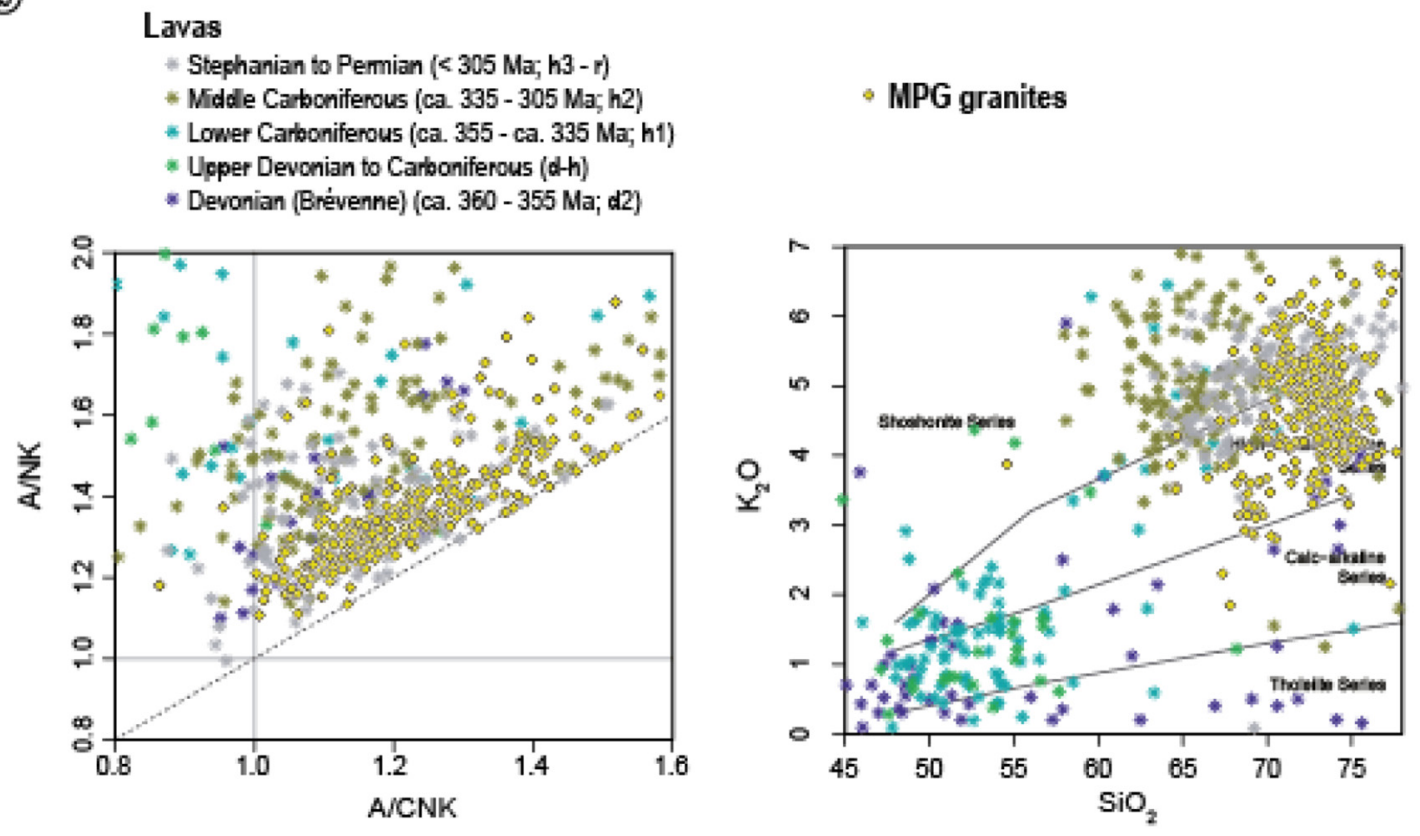

Fig. 13. Geochemistry of magmatic rocks of the French Massif Central. a) Two mantle sources in the Massif Central (calculated at 315 Ma, an average between the c. $335 \mathrm{Ma}$ lavas and the ca $305 \mathrm{Ma}$ lamprophyres and vaugnerites): note the clear difference between the pre-335 mafic magmas (lavas from the Brévenne Unit (Pin and Paquette, 1997) and diverse lavas from NE Massif Central (Pin and Paquette, 2002)), and the post-335 Ma lavas (lamprophyres: (Agranier 2001); enclaves in granites (Pin, 1990) and vaugnerites (Williamson et al., 1992); underplated mafic magmas (or cumulates) found as enclave in the Cenozoic Bournac volcano (Downes et al., 1990)). b) Change in the nature of the lavas, in Shand (1943) A/CNK vs. A/NK and Peccerillo and Taylor (1976) $\mathrm{SiO}_{2}-\mathrm{K}_{2} \mathrm{O}$ diagrams. Pre-335 Ma lavas are mafic and metaluminous, whereas post-335 Ma lavas are felsic, high-K and peraluminous, essentially similar to MPG granites forming at the same age.

NE-SW trending shallow-dipping shear zone (Feybesse et al., 1988), also delineated by a syntectonic granite displaying a $\mathrm{C} / \mathrm{S}$ fabric consistent with a top to the NW sense of shear (Feybesse et al., 1988; Leloix et al., 1999). Deformation of this granite is dated at $339-337 \mathrm{Ma}$ by ${ }^{40} \mathrm{Ar} /{ }^{39} \mathrm{Ar}$ on recrystallized muscovite (Faure et al., 2002), which is consistent with both $\mathrm{Rb}-\mathrm{Sr}$ whole rock isochrons obtained by Gay et al. (1981) on the syntectonic granite and by Vialette (1973) on genetically linked hypovolcanics (Leloix et al., 1999; Faure et al., 2002), giving ages at $339 \pm 8$ and $336 \pm 5$ Ma respectively. These data 


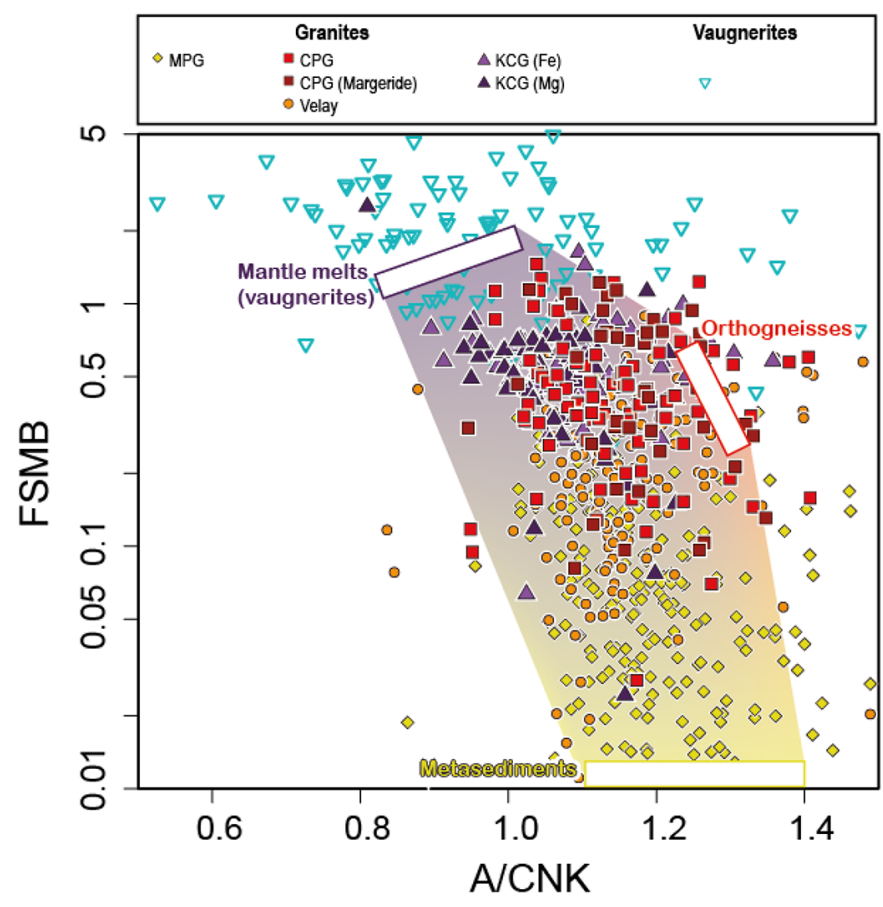

Fig. 14. Geochemical characteristics of magmatic rocks exposed in the East French Massif Central. Summary of the geochemical characteristics of E-FMC granitoids, in a A/CNK (molar $\mathrm{Al}_{2} \mathrm{O}_{3} / \mathrm{CaO}+\mathrm{Na}_{2} \mathrm{O}$ $+\mathrm{K}_{2} \mathrm{O}$ diagram, Shand 1943) vs. FSMB $((\mathrm{FeOt}+\mathrm{MgO}) \times(\mathrm{Sr}(\mathrm{wt}$. $\%)+\mathrm{Ba}(\mathrm{wt} . \%)$ ) diagram (Laurent et al., 2014). This diagram separates granitoids related to different sources (Moyen et al., 2017), and shows that KCG are primarily related to the differentiation of vaugnerites (with minor crustal components occasionaly); MPG are related to a metasedimentary source; CPG are generated from a source dominated by orthogneisses, but with more common involvement of either a metasedimentary component (particularly pronounced in the Velay complex) or a mafic component (e.g. the Margeride granite).

suggest that at least part of the exhumation of the UGU in this region occurred during the early Carboniferous and was associated with top to the NW shearing. In the Livradois (Fig. 8, section CC'), the southern part of the migmatitic UGU nappe is cut by dextral-reverse transcurrent shear zones and associated syntectonic peraluminous granodiorite and leucogranite plutons (CPG and MPG) dated by TIMS U-Pb on zircon at $315 \pm 4$ and $311 \pm 18 \mathrm{Ma}$, respectively (Solgadi et al., 2007; Gardien et al., 2011; Vanderhaeghe et al., 2013), which provides a maximum age for the exhumation of these rocks. The geochronological data obtained on the HP migmatites of the UGU in the Lyonnais and Livradois are significantly younger than the ones obtained in the Sioule area and we propose to attribute these rocks to the central nappe.

In the Haut-Allier area (Fig. 8, section CC'), the foliation of the UGU flattens to the south and delineates a dome cored by migmatites attributed to the LGU (Burg and Matte, 1978; Gardien et al., 2011). In the Artense, Truyere, and Marvejols regions, amphibolite facies paragneisses attributed to the LGU and greenschist facies micaschists attributed to the PAU define an inverted metamorphic gradient with respect to the overlying UGU (Ledru et al., 1989; Mercier et al., 1991a). Amphibolites of the UGU contain thin tonalitic to trondhjemitic layers interpreted to reflect high-pressure partial melting (Nicollet and Leyreloup, 1978; Pin and Lancelot, 1982). This highpressure metamorphism has been dated by zircon TIMS U-Pb analyses at $432+20 /-10 \mathrm{Ma}$ in the Haut Allier (Ducrot et al., 1983), $415 \pm 6 \mathrm{Ma}$ in Marvejols (Pin and Lancelot, 1982) and at $413 \pm 23$ and $408 \pm 7$ by $\mathrm{Pb}-\mathrm{Pb}$ on zircon and a $\mathrm{Sm}-\mathrm{Nd}$ whole rock and garnet isochron respectively in the Rouergue (Paquette et al., 1995). Retrograde amphibolite facies metamorphism is recorded by lower intercepts defined by discordant $\mathrm{U}-\mathrm{Pb}$ zircon data at $345-340 \mathrm{Ma}$ obtained on paragneisses and amphibolites (Pin and Lancelot, 1982). The UGU-LGU contact is intruded by the Margeride laccolithic composite pluton (Couturié et al., 1979; Couturié and CaenVachette, 1980; Talbot et al., 2005). The main porphyritic monzogranite yields $\mathrm{U}-\mathrm{Pb}$ zircon dates of $334 \pm 9 \mathrm{Ma}$ (Respaut, 1984) and of $313 \pm 2 \mathrm{Ma}$ (Laurent et al., 2017) and $\mathrm{a} \mathrm{U}-\mathrm{Pb}$ on monazite of $314 \pm 3 \mathrm{Ma}$ (Pin, 1979). The leucogranitic facies cross cutting the monzogranite is dated by various methods from 311 to 298 (Couturié and CaenVachette, 1980; Lafon and Respaut, 1988; Monié et al., 2000; Laurent et al., 2017). In the Vivarais (Fig. 8, section DD'), several klippes of UGU made of migmatites including amphibolite enclaves overly paragneisses and orthogneisses of the LGU, outlining an inverted metamorphic gradient (Gardien, 1993). Rocks of the UGU have recorded HT eclogitic to HP granulitic metamorphic conditions up to $15 \mathrm{kbar}$ at c. $800^{\circ} \mathrm{C}$, followed by retrogression at $5 \mathrm{kbar}$ at c. $550{ }^{\circ} \mathrm{C}$ (Gardien, 1993). The HP migmatitic gneisses and amphibolites of the UGU contain zircon with metamorphic rims dated by $\mathrm{U}-\mathrm{Pb}$ at $351.5 \pm 3.0 \mathrm{Ma}$ and $343.5 \pm 2.6 \mathrm{Ma}$, respectively and interpreted to represent retrogression of the eclogite into amphibolite facies after tectonic accretion during continental collision (Chelle-Michou et al., 2017). The underlying paragneisses display low-pressure granulite facies metamorphism associated with widespread partial melting dated at ca. $308 \mathrm{Ma}$ (Chelle-Michou et al., 2017). These zones in the Vivarais, Marvejols and Rouergue, with an inverted metamorphic gradient might correspond to the southern tip of the UGU central nappe.

To the south of the Rouergue, the Najac eclogites have recorded a pressure of 15-20 kbar and a temperature of 560 $630{ }^{\circ} \mathrm{C}$ (Lotout et al., 2018). Eclogite-facies metamorphism is dated by $\mathrm{U}-\mathrm{Pb}$ on zircon at $385.5 \pm 2.3 \mathrm{Ma}$, by Lu-Hf on garnet cores at $382.8 \pm 1.0 \mathrm{Ma}$, and by a Sm-Nd amphibole-garnetwhole rock isochron of $376.7 \pm 3.3 \mathrm{Ma}$. Subsequent exhumation and cooling below c. $500{ }^{\circ} \mathrm{C}$ are constrained by an apatite $\mathrm{U}-\mathrm{Pb}$ age at $369 \pm 13 \mathrm{Ma}$. The maximum temperature reached by these eclogites is significantly lower than the ones recorded by eclogites enclosed in the granulite facies migmatites of the UGU. Moreoever, geochronological data available for the Najac clogites point to burial coeval with the UGU central nappe exposed in the Haut-Allier, Marvejols and Rouergue, but also for a much older exhumation. These data suggest that the Najac eclogites are part of a nappe equivalent to the MAU, which has a different P-T-t history than the UGU.

The Velay and Montagne Noire migmatite domes correspond to the lowermost exposed structural level of the E-FMC (Figs. 4 and 8 section CC', DD'). These migmatites originated by partial melting of paragneisses and orthogneisses under MP to LP conditions at the bottom of the nappe pile from c. 320 to c. $300 \mathrm{Ma}$ (Montel et al., 1992; Williamson et al., 1996; Downes et al., 1997; Barbey et al., 1999, 2015; 


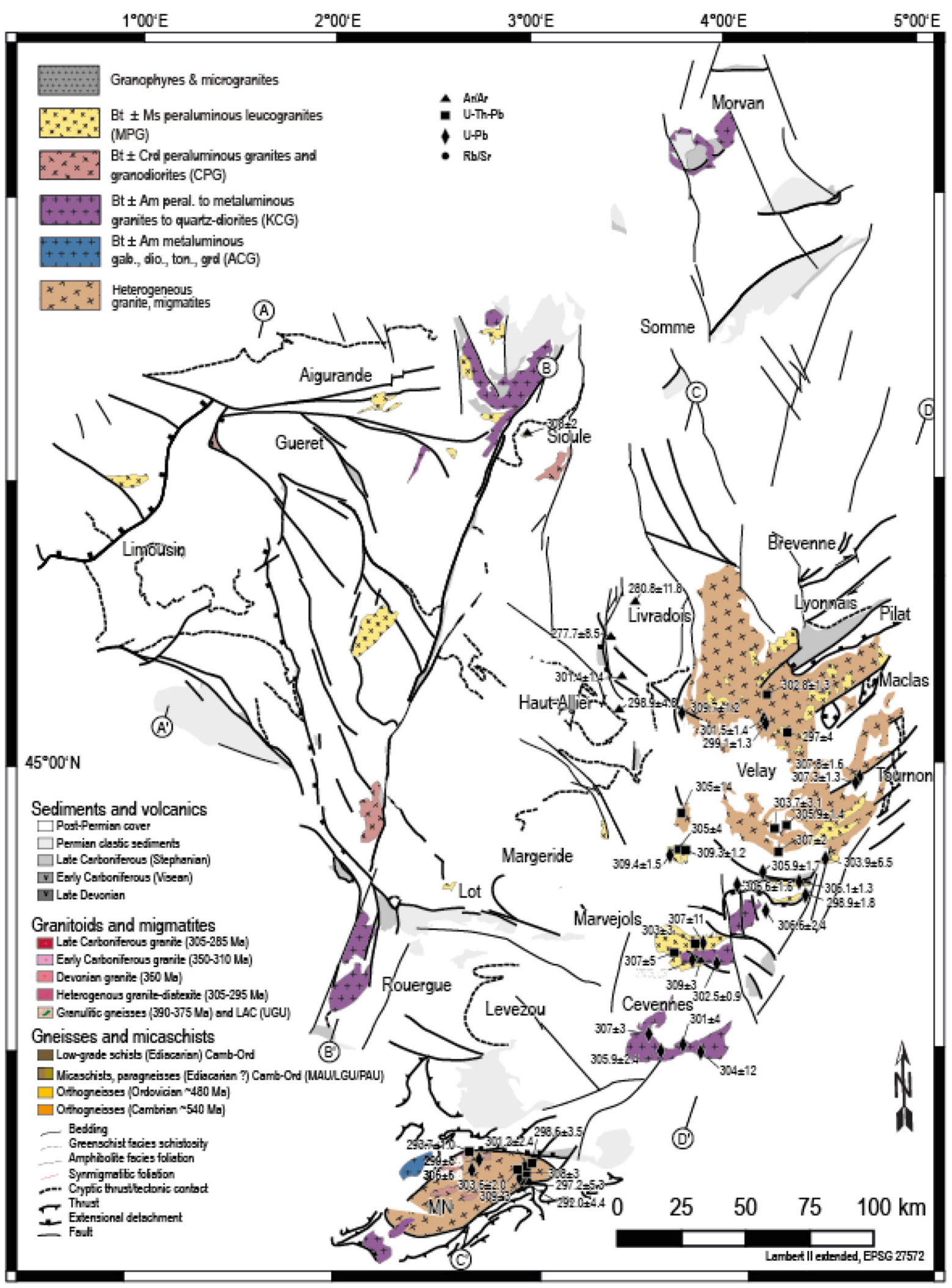

Fig. 15. Late Carboniferous-Permian magmatism. Magmatic rocks with ages ranging from c. 305 to c. 295 Ma are localized along the Sillon Houiller and are present as plutons and in the core of large migmatite domes (Velay, Montagne Noire) in the eastern part of the French Massif Central. The presence of plutonic rocks to the south of the French Massif Central suggests that the partially molten source has migrated since the Lower Carboniferous from the internal to external zone of the Variscan belt. The combination of MPG-type, CPG-type and KCG-type granites emplaced during this period is consistent with the contribution of crustal and mantle sources and is interpreted as reflecting the impact of southward slab retreat that is more pronounced beneath the eastern part of the French Massif Central. 
Ledru et al., 2001; Villaros et al., 2018) and contain dismembered enclaves of vaugnerites (Michon, 1987; Sabatier, 1991; Ledru et al., 2001; Couzinié et al., 2014). The $100 \mathrm{~km}$-wide, first-order Velay dome is delineated by the foliation of the surrounding paragneisses and orthogneisses (Lagarde et al., 1994). The synmigmatitic foliation defines subdomes with an average diameter of $10-20 \mathrm{~km}$ and characterized by a radial distribution of the HT mineral lineation (Ledru et al., 2001). Accordingly, the Velay dome is a crustal-scale structure interpreted to represent the exhumed middle part of the orogenic crust. The western boundary of the dome is subvertical and its southern part is overturned toward the south (Burg and Vanderhaeghe, 1993; Vanderhaeghe et al., 1999; Ledru et al., 2001). Along the eastern side of the dome, in the Vivarais region, the symigmatitic foliation is shallow-dipping and small klippen of the HP migmatites belonging to the UGU central nappe, as described above, are exposed above LGU grading into MP to LP migmatites (Gay et al., 1982; Gardien, 1993; Gardien and Lardeaux, 1991; Chelle-Michou et al., 2017). The superposition of the HP migmatites attributed to the UGU on top of the LGU is inferred to represent an inverted metamorphic gradient preserved from the time of the nappe emplacement. In turn, the downsection transition from midamphibolite facies metamorphism documented in the LGU just beneath the UGU to MP and LP migmatites of the Velay dome corresponds to a normal metamorphic gradient marked by an important increase in temperature with depth.

The northern part of the Velay dome is delimited by the Pilat mylonitic low-angle detachment intersected by high angle cataclastic normal faults (Malavieille et al., 1990; Gardien et al., 1997). Heterogeneous granite (i.e. diatexites) in the core of the dome shows a relatively tight cluster of U-Pb ages on zircon and monazite, in the range of $307 \pm 2$ to $301 \pm 5$ Ma (Mougeot et al., 1997; Couzinié et al., 2014; Chelle-Michou et al., 2017; Laurent et al., 2017). Magmatic zircon grains and rims with ages ranging from 340 to $300 \mathrm{Ma}$ (Chelle-Michou et al., 2017; Laurent et al., 2017) point to a protracted history of zircon growth and/or dissolutionreprecipitation in these diatexites. To the north of the Velay the Gouffre d'Enfer syntectonic granite, emplaced within the Pilat detachment, yielded an unprecise whole rock $\mathrm{Rb}-\mathrm{Sr}$ age of $322 \pm 26 \mathrm{Ma}$ (Caen-Vachette et al., 1984; Vitel, 1988). To the south of the Velay dome, a Rb-Sr isochron of $302 \pm 4 \mathrm{Ma}$ has been obtained for the Rocles syntectonic granite (Caen-Vachette et al., 1981) emplaced in a detachment that has been overturned later on (Burg and Vanderhaeghe, 1993; Vanderhaeghe et al., 1999; Bouilhol et al., 2006). U-Th-Pb ages by EMPA on monazite of $324 \pm 4 \mathrm{Ma}$ and $325 \pm 5 \mathrm{Ma}$ have also been obtained for the the Rocles granite (Bé Mézémé, 2005; Bé Mézémé et al., 2006), which overlap with a more reliable $\mathrm{U}-\mathrm{Pb}$ zircon LA-ICPMS age of $320.3 \pm 3.8 \mathrm{Ma}$ (Couzinié, 2017). This suggests that while the Rocles granite was emplaced at c. $320 \mathrm{Ma}$, the $\mathrm{Rb}-\mathrm{Sr}$ system was probably reset at $302 \mathrm{Ma}$. Migmatites and heterogeneous granite of the core of the dome are intruded by small plutons and dykes of CPG/MPG with sharp contacts designated as late-migmatitic (Montel and Abdelghaffar, 1993) dated by U-Th-Pb on monazite (LA-ICPMS) from $307 \pm 2$ to $297 \pm 4$ Ma (Didier et al., 2013). They are characterized by an aluminous and potassic signature and are rich in rounded enclaves of metapelites and of microdiorite suggesting a metapelitic source together with a contribution from a magma generated by partial melting of an enriched mantle (Villaros et al., 2018). Microgranites with similar chemical signatures have yielded identical U-Th-Pb EMPA ages on monazite at about $300 \mathrm{Ma}$ $(306 \pm 12,291 \pm 9 \mathrm{Ma})$ but also at about $255 \mathrm{Ma}(257 \pm 8$ and $252 \pm 11 \mathrm{Ma}$ ), which points to either a Permian crystallisation or to hydrothermal perturbation at this time (Montel et al., 2002). High-angle normal faults rooting in the low-angle detachments, delimit the late Carboniferous St. Etienne, Jaujac and Alès extensional basins filled by coarse detrital sediments including clasts from the migmatites and granites interbedded with volcanic deposits (rhyolitic ash fall tuffs and accretionary lapilli) and coal-bearing sediments (Becq-Giraudon et al., 1996).

The Montagne Noire is characterized by a dome structure with a core of migmatitic gneisses and a mantle of low-grade metasedimentary rocks (Gèze, 1949; Arthaud et al., 1966; Ellenberger, 1967; Engel et al., 1978, 1981; Demange, 1980; Demange and Jamet, 1985). Migmatites and orthogneisses in the core of the dome display a prolate finite strain ellipsoid indicative of constriction with a subhorizontal long axis parallel to the axis of the elliptical shape dome (Echtler and Malavieille, 1990; Matte et al., 1998; Rabin et al., 2015). Migmatites coring the Caroux dome in the Montagne Noire have recorded P-T conditions of $6 \mathrm{kbar}$ and $720^{\circ} \mathrm{C}$ (Rabin et al., 2015) and they are juxtaposed to low-grade LP/HT micaschists (Thompson and Bard, 1982; Demange and Jamet, 1985). Magmatic zircon from the migmatites yield U-Pb ages spreading from c. 330 to c. $300 \mathrm{Ma}$ (Franke et al., 2011; Faure et al., 2014; Roger et al., 2015). Migmatites contain mafic enclaves that have preserved relicts of eclogite facies metamorphism (Demange, 1980; Faure et al., 2014). Zircon grains from the eclogite facies rocks yield two age peaks, one at c. $360 \mathrm{Ma}$ and the other at c. $315 \mathrm{Ma}$, with a few discordant ages pointing at an early Paleozoic heritage (Faure et al., 2014; Whitney et al., 2015). Faure et al. (2014) attribute the 360 Ma age to eclogite facies metamorphism whereas Whitney et al. (2015), based on REE signatures of the different zircon zones, argue that eclogite facies is recorded by the $315 \mathrm{Ma}$ age. The Montalet syntectonic granite emplaced along the northern side of the Montagne Noire yield a U-Pb age on zircon of $294 \mathrm{Ma}$ (Poilvet et al., 2011). This syntectonic granite is juxtaposed to the late Carboniferous Graissessac basin along a mylonitic to cataclastic detachment (Van Den Driessche and Brun, 1992). Many different models have been proposed for the Montagne Noire, the dome structure having been interpreted as (i) an anticline developed by horizontal shortening (Matte et al., 1998) (Fig. 7), (ii) a ductile layer exhumed in a pull-apart basin (Nicolas et al., 1977; Rey et al., 2011; Whitney et al., 2015), (iii) a diapir (Charles et al., 2009), (iv) an eroded antiformal stack (Malavieille, 2010) or (v) a Metamorphic Core Complex formed as a consequence of gravitational collapse of the Variscan belt during convergence (Echtler, 1990; Echtler and Malavieille, 1990; Aerden, 1998; Aerden and Malavieille, 1999) or during regional extension (Van Den Driessche and Brun, 1992).

\section{Previous tectonic-geodynamic reconstructions and debated issues}

In this section, we present the various tectonic-geodynamic reconstructions that were proposed at the scale of the Variscan 
belt with a focus on the French Massif Central, with the aim of identifying robust features but also to point at the discrepancies and shortcomings.

\subsection{Monocyclic doubly-vergent orogen model}

Early geodynamic reconstructions at the scale of Western Europe invoked a doubly-plunging subduction system based on the presence of the two major suture zones described above, namely the Rheic suture and the Medio-European suture, and opposite vergence of structures on the northern and southern sides of the orogenic belt (Matte, 1986, 1991, 2001) (Fig. 2A). According to the latest version of this model, Silurian subduction of Ordovician oceanic basins along the southern branch of the Variscan Belt was followed by Devonian continental subduction and Carboniferous collision between Laurussia and Gondwana (Matte, 2001). This model, mostly relying on a synthesis of structural, metamorphic and sedimentary data, provides a first order tectonic-geodynamic framework for the Variscan belt. In contrast, other geodynamic models assuming that Armorica remained attached to the north Gondwana margin do not include the closure of a MedioEuropean Ocean (e.g. Nance et al., 2010) and thus fail to account for the presence of ophiolitic assemblages to the south of Armorica. Still, the reconstructions proposed by Matte (1986, 1991, 2001) elude some key features including (i) the presence of a late Devonian arc and back-arc association in the Vosges (Skrzypek et al., 2012) and the Eastern Massif Central (Somme and Brévenne Units, see above); (ii) the mechanisms of exhumation of eclogites and migmatites, and, most of all, (iii) syn-orogenic partial melting and magmatism that are notably absent from the cross sections despite the vast exposed surface represented by migmatites and granites. Note also that in the scenario proposed by Matte $(1986,1991,2001)$, the HP rocks of the UGU are issued from the southern margin of Armorica, i.e. the upper plate relative to Silurian-Devonian subduction. Accordingly, from their position, it is unclear how these rocks could have been buried to granulite facies and then exhumed back to the surface.

\subsection{Polycyclic orogenic model}

Faure et al. (1997) refined the geodynamic model elaborated by Matte $(1986,1991,2001)$ in order to account for the late-Devonian magmatic arc and back-arc inferring a southward subduction of the Rheic Ocean based on the relative position of the Somme Unit to the north of the Brévenne Unit (Fig. 3). These authors propose a polcyclic model for the tectonic evolution of the Variscan belt in Western Europe with two distinct orogenic phases (Fig. 2B). The first orogenic phase is associated with northward oceanic subduction during the Silurian and Devonian leading to the closure of the MedioEuropean Ocean followed by continental subduction during the early Devonian and exhumation of the UGU before the late Devonian. This model provides an explanation for highpressure metamorphism, which is attributed to burial of rocks from the Gondwana margin that first have been dragged with the downgoing plate and then decoupled from it allowing their exhumation. It should be noted that mafic and ultramafic rocks of the LAC are described by Faure et al. (2008) as part of the
UGU but are not considered to represent an ophiolite, which is at odds with the interpretations of most authors. For example, to explain the intimate association of mafic and felsic HP rocks, Lardeaux (2014) proposes that the UGU and the LAC represent the formerly thinned continental margin of Gondwana (Fig. 2B). Irrespective of these differences, all these authors invoke a second orogenic phase associated with southward subduction of the Rheic Ocean during the late Devonian beneath an upper plate, made of the exhumed, HP UGU nappe. The latter undergoes extension as attested by the late Devonian Brévenne back-arc rift basin (Fig. 2B). In this model, partial melting of the UGU is attributed to retrogression owing to decompression during syn-orogenic exhumation whereas partial melting of the underthrusted LGU is interpreted to be caused by burial beneath the UGU (Fig. 2B). At the lithospheric scale, a high-velocity anomaly beneath the Paris Basin detected in tomographic models is proposed to represent a remnant of this southward subducting slab (Averbuch and Piromallo, 2012). As an alternative, Lardeaux et al. (2001) advocated that the late Devonian Brévenne back-arc basin was opened above a northward subducting slab (corresponding to the former Medio European Ocean) at the time of exhumation of the UGU and was closed as a consequence of collision between Armorica and Gondwana. Despite differences in the polarity of subduction, all these authors attribute Carboniferous deformation, metamorphism and magmatism in the French Massif Central to crustal thickening owing to post Devonian continental collision followed by delamination of the lithospheric root beneath the orogenic belt (Lardeaux et al., 2001; Faure et al., 2002; Lardeaux, 2014; Lardeaux et al., 2014). This model considers implicitely that the UGU represents a single nappe exhumed and emplaced above the LGU before the opening of the late Devonian Brévenne back-arc basin.

\subsection{Collision versus syn-orogenic extension during the Carboniferous}

The tectonic-geodynamic setting leading to the construction-evolution of the Variscan belt has also been actively debated for the Carboniferous period. The mid- to lateCarboniferous is marked by (i) regional-scale strike-slip shear zones and a NW-SE trending stretching lineation parallel to the belt throughout the French Massif Central (Arthaud and Matte, 1975; Mollier and Bouchez, 1982; Lardeaux and Dufour, 1987; Gébelin et al., 2007, 2009); (ii) the exhumation of metamorphic rocks and the emplacement of syntectonic plutons beneath low-angle detachements (Faure and Pons, 1991; Roig and Faure, 2000); and (iii) fold and thrust belts in the foreland of the Variscan belt as exemplified in the Ardennes (Sintubin et al., 2009) and in the Montagne Noire (Echtler, 1990). These features have been interpreted as reflecting either lateral escape of crustal blocks during progressive construction of the orogenic belt following continental collision (Arthaud and Matte, 1975; Matte, 1986; Burg et al., 1987; Lardeaux and Dufour, 1987; Gébelin et al., 2007), syn-orogenic extension of the thickened orogenic crust (Burg et al., 1993; Faure, 1995), or syn-convergent extension (Gébelin et al., 2009).

For the late Carboniferous-Permian period, gravitational collapse of the Variscan belt has been recognized through the development of a rift system superimposed on the thickened crust (Ménard and Molnar, 1988) and by the identification of 
low-angle detachments in the French MassifCentral (Malavieille et al., 1990; Burg et al., 1993; Faure, 1995; Gardien et al., 1997; Vanderhaeghe et al., 1999; Bouilhol et al., 2006). For the same late Carboniferous period, the prevailing tectonic-geodynamic model for the nearby Pyrénées, south of the FMC, favours a context of transpression (Gleizes et al., 1997; Laumonier et al., 2010; Denèle et al., 2014; Cochelin et al., 2017) although models invoking regional extension have also been proposed (Wickham et al., 1987; Gibson, 1991). On the other hand, a synthesis at the scale of western Europe reveals that the late Devonian to earlymid Carboniferous (Visean) sedimentary record, preserved locally in the internal zone and in the foreland of the Variscan belt, is dominated by platform carbonates and pelagic deposits, which is not in favour of the presence of a Tibetan-type elevated orogenic plateau for this time period and questions the pertinence of the concept of orogenic collapse applied to the Variscan belt (Franke, 2014). Nevertheless, these Visean carbonate deposits have not been identified in the intermediate part of the French Massif Central, in between the Brévenne region and the Montagne Noire. The near absence of late Devonian to middle Carboniferous deposits in the W-FMC, contrasts with their abundance in the E-FMC and suggests either that it was at higher altitude at this time or that these deposits have been eroded. At last, as pointed by Franke et al. (2011), it should be noted that foreland deposits are underlain in the Montagne Noire and in the Pyrénées by rocks affected by HT/LP metamorphism and deformation during the Variscan orogeny, which are not typical characteristics of external zones of orogenic belts.

\subsection{Impact of partial melting and magmatism on Variscan tectonics?}

Despite the predominance of plutonic and migmatitic rocks in the French Massif Central, and more generally in the Variscan belt (Zwart, 1967), early tectonic models partly eluded the relationships between HT metamorphism, magmatism and orogenic evolution (Matte, 1986, 1991). During the 1980s, progress on experimental petrology and thermodynamic modelling (Wyllie, 1977; Vielzeuf and Holloway, 1988; Spear and Cheney, 1989; Gardien et al., 1995) has allowed to identify the P-T conditions of partial melting during orogenic evolution and discuss their tectonic-geodynamic significance (England and Thompson, 1984; Thompson and Connolly, 1995). In the French Massif Central, partial melting has been identified throughout the high-grade nappe pile and is associated with HP, MP and LP metamorphism. Highpressure granulite to amphibolite facies migmatites dated from the early to the middle Devonian are interpreted to record either partial melting during exhumation of the UGU (Faure et al., 1997, 2008) or to magmatic arc accretion (Lardeaux, 2014). Intermediate pressure migmatites typically associated with Barrovian metamorphism with ages spreading from the middle Devonian to the middle Carboniferous (from c. 370 to c. $310 \mathrm{Ma}$ ) are interpreted as reflecting continental collision marked by nappe emplacement (Montel et al., 1992; Ledru et al., 1994; Faure et al., 2008; Barbey et al., 2015) and/or a mantle heat supply owing to asthenospheric upwelling as a consequence of lithospheric delamination (Faure et al., 2002, 2009a). The last partial melting event is characterized by low-pressure migmatites and granites exposed in large domes is attributed to a temperature increase caused by the emplacement of mantlederived magmas (vaugnerites) during late-orogenic collapse (Montel et al., 1992; Ledru et al., 1994; Barbey et al., 2015). Each of these migmatite types are therefore dominantly regarded as recording discrete, short-lived events of partial melting associated with prograde metamorphism. This is in conflict with the fact that the solubility of accessory minerals in silicate liquids during melting and crystallization is positively correlated with temperature (Harrison and Watson, 1983; Watson and Harrison, 1983; Boehnke et al., 2013). Consistently, thermodynamic modelling shows that zircon and monazite, the most common geochronometers in migmatites, preferentially crystallize during the retrograde (cooling) path and only seldom preserve a record of the prograde path (Kelsey et al., 2008; Yakymchuk and Brown, 2014).

The discrepancies beween tectonic and geodynamic models proposed for different parts of the Variscan belt of Western Europe illustrate the difficulty in tracking the continuity of terranes and sutures. They potentially point to a non-cylindrical structure marked by discontinuous ribbonshaped continental terranes separated by immature oceanic basins. Furthermore, these discrepancies reflect differences in the interpretation of the geological record in terms of metamorphism, magmatism and deformation. Until now, the existing models have failed to integrate the impact of partial melting and of the generation of magmatic rocks on orogenic evolution. We hereby provide a novel synthetic model for the geodynamic-tectonic evolution of the Variscan belt integrating most of the existing data summarized in the previous paragraphs. In contrast with previous models, we emphasize the pivotal role of protracted partial melting and magmatism on the rheology of the orogenic crust and thus on the tectonicgeodynamic evolution of the Variscan belt.

\section{New model for the geodynamic-tectonic evolution of the Variscan belt of Western Europe}

\subsection{Pre-Variscan configuration: the North Gondwana hyper-extended margin}

As presented in Section 2.1, the relative position of the cratons, the numbers and sizes of continental terranes and oceanic basins, and the polarity of subductions are all actively debated owing to discrepancies between paleomagnetic and paleobiostratigraphic data, and to uncertainties in tectonic reconstructions. The ophiolitic assemblages with different protoliths and peak ages as well as contrasting peak temperatures identified in the French Massif Central, in the Armorican Massif, and in the Vosges (Hanmer, 1977; BernardGriffiths and Cornichet, 1985; Girardeau et al., 1986; Santallier et al., 1988; Burg et al., 1989a, 1989b; Dubuisson et al., 1989; Mercier et al., 1991a; Bosse et al., 2000; Lardeaux et al., 2001; Ballèvre et al., 2009; Berger et al., 2010a; Skrzypek et al., 2012; Lotout et al., 2018), might represent different sutures that might have corresponded to former rift and/or oceanic basins separating former crustal blocks. This scheme is consistent with the pre-Variscan record of the micaschists, paragneisses and orthogneisses forming the UGU, MAU, LGU and their relative para-autochthon exposed in the 
French Massif Central and the Pyrenées (Fig. 5, Tabs. 1-3). Namely, Ediacaran sediments intruded by Cambrian granitic plutons represent a Cadomian basement for the thick detrital sedimentary sequences of lower Paleozoic age deposited during the post-Pan-African dislocation of the Gondwana continent (Duthou et al., 1981, 1984; R'Kha Chaham et al., 1990; Alexandrov et al., 2001; Chelle-Michou et al., 2017; Couzinié et al., 2017, 2019). Other orthogneisses with intrusive contacts (dyke networks, contact metamorphism) of Ordovician age, represent former laccoliths emplaced during extension along the northern margin of the Gondwana continent (Lasnier, 1968; Bernard-Griffiths, 1975; BernardGriffiths et al., 1977; Duthou et al., 1981, 1984; R'Kha Chaham et al., 1990; Pin and Marini, 1993; Barbey et al., 2001; Deloule et al., 2002; Roger et al., 2004; Cocherie et al., 2005; Castiñeiras et al., 2008; Melleton et al., 2010; Lotout et al., 2017). The calc-alkaline to tholeiitic chemical signature of the LAC also suggests an emplacement of this bimodal magmatic suite in a continental to oceanic rift environment during the Cambrian-Ordovician (Pin and Lancelot, 1982; Bodinier et al., 1986; Briand et al., 1995; Chelle-Michou et al., 2017). PreNeoproterozoic rocks, such as the Archean to Paleoproterozoic Icartian gneisses exposed in the northern Armorican Massif (D'Lemos et al., 1990; Le Corre et al., 1991), have not been identified in the French Massif Central. As already mentioned by other authors (Bouchardon et al., 1989; Pin, 1990; Faure et al., 1997; Lardeaux, 2014; Franke et al., 2017), these data are consistent with the development of a thinned continental margin with one or several immature rifts and/or oceanic basins along the hyperextended northern continental margin of the Gondwana craton.

Accordingly, a two-stage geodynamic model is proposed for the pre-Variscan configuration of the French Massif Central. During the Cambrian (Figs. 16A and 17A), subduction of the Iapetus Ocean along the Gondwana margin was marked by the emplacement of calc-alkaline plutonic and volcanosedimentary rocks (D'Lemos et al., 1990; Le Corre et al., 1991). Crustal extension and opening of rifts at the rear of this active margin during the Ordovician might have been favoured by retreat of the Iapetus slab leading to the opening of the Medio-European Ocean (Figs. 16B and 17B). Such a hyper-extended margin might have spread over several hundred kilometres from the Ordovician to early Silurian and might conciliate the apparent contradiction between paleomagnetic reconstructions implying a distance of more than $2000 \mathrm{~km}$ between Gondwana and Laurussia during the Ordovician and paleontologic data pointing to small communicating basins. Accordingly, the Variscan orogenic belt is essentially made of a reworked continental crust made of a Cadomian basement affected by post Pan-African Ordovician hyper-extension, intruded by granitoids and covered by thick volcanic-sedimentary series. Reworking of this hyperextended margin occurred as a consequence of convergence between Laurussia and Gondwana from the Silurian to the Carboniferous (Figs. 17C-E).

\subsection{Late Silurian to Devonian subduction and HP partial melting of terranes issued from the North Gondwana margin}

As described in the previous sections, the oldest evidence for the onset of the Variscan orogenic cycle corresponds to the
HP metamorphism identified in mafic and ultramafic rocks of the LAC (Fig. 4) pointing to subduction of these units (Lasnier, 1968, 1971; Pin and Vielzeuf, 1983; Bouchardon et al., 1989; Gardien et al., 1990). The presence of UHP mineral assemblages in the LAC of the Lyonnais (Lardeaux et al., 2001) and Limousin (Berger et al., 2010a, 2010b), argues for burial of these units to a depth of more than $100 \mathrm{~km}$. Nevertheless, two types of eclogites are distinguished, namely (i) HT eclogites that are forming enclaves-boudins into migmatites of the UGU as exemplified in the Aigurande, north Limousin, Sioule, Livradois, Lyonnais, Rouergue regions (Pin and Vielzeuf, 1983; Dufour, 1985; Burg et al., 1989a, 1989b; Gardien, 1990; Gardien et al., 1990; Lardeaux et al., 2001; Faure et al., 2008); and (ii) LT eclogites that are hosted by micaschists not affected by partial melting as illustrated by the MAU exposed in south Limousin or in Najac (Berger et al., 2010a; Lotout et al., 2018). According to the few available geochronological data, subduction of these units is diachronous and occurred from the late Silurian to the Devonian (Fig. 18A-C) (Pin and Lancelot, 1982; Ducrot et al., 1983; Paquette et al., 1995; Berger et al., 2010a; Do Couto et al., 2016; Lotout et al., 2018).

A similar nappe pile has been described in the South Armorican Massif, with the distinction of HT and LT eclogites (Ballèvre et al., 2009). The core of the Champtoceaux nappe is made of granulite facies migmatitic gneisses, with enclaves of ultramafic rocks with HT eclogite facies relics (Marchand, 1981; Ballèvre et al., 1987, 2002; Godard, 2001). These rocks overlay lower grade orthogneisses and micaschists that contain mafic boudins with LT eclogite facies relics. LT eclogites and blueschist facies rocks of the Ile de Groix are in a similar structural position as the MAU in the FMC and have been interpreted to represent the suture of the Galicia-South Brittany Lower Paleozoic Ocean. ${ }^{40} \mathrm{Ar} /{ }^{39} \mathrm{Ar}$ and $\mathrm{Rb}-\mathrm{Sr}$ dating of blueschist facies rocks, yield c. $360 \mathrm{Ma}$ for the metamorphic peak attributed to subduction of this ocean at the DevonianCarboniferous transition. Greenschist facies retrogression of these rocks reflects cooling and exhumation dated in the early Carboniferous as constrainted by ages ranging from 355 to $340 \mathrm{Ma}$ (Bosse et al., 2000, 2005; Paquette et al., 2017).

Mafic-ultramafic enclaves with relictual HT eclogitic facies metamorphism enclosed in granulite facies migmatites was also identified in other Variscan massifs. In the Vosges, garnetlherzolite belonging to a subcontinental lithospheric mantle exhumed from more than $150 \mathrm{~km}$ are present in the varied gneiss unit dominated by granulite facies migmatitic gneiss (Altherr and Kalt, 1996; Brueckner and Medaris, 2000; O'Brien and Rötzler, 2003). The Bohemian massif also comprises large mafic and ultramafic bodies enclosed in high-grade gneisses (Kusbach et al., 2012). In the French Massif Central, ages interpreted to record eclogite facies peak metamorphism are typically 20 to $30 \mathrm{Ma}$ older to the ones attributed to granulite facies metamorphism and partial melting of their host migmatitic paragneisses and orthogneisses (Duthou et al., 1981, 1994; Pin and Lancelot, 1982; Chelle-Michou et al., 2017).

The significance of this association and of this age gap is debated. The question is whether it represents (i) a premetamorphic association reflecting intrusion of mafic magmas into the crust or tectonic accretion of oceanic and continental terranes, (ii) a syn-metamorphic extrusion of mantle into the lower crust, (iii) or a subduction of the continental crust and 
a. Cambrien (541-485 Ma)

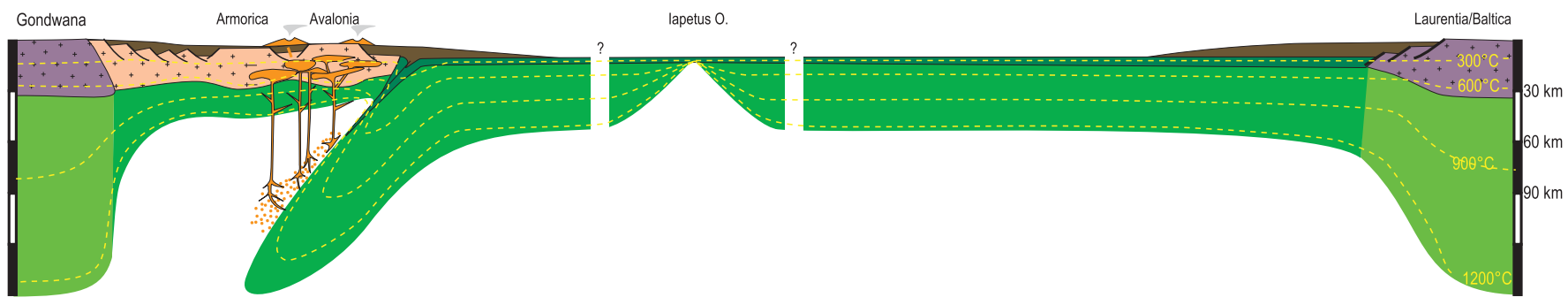

b. Ordovician (485-444 Ma)

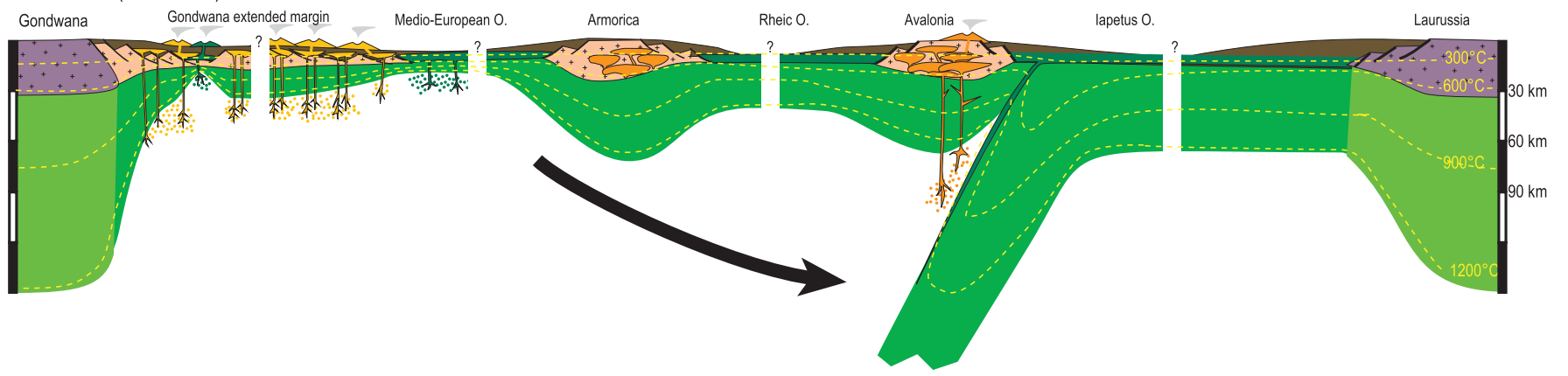

Fig. 16. Pre-Variscan geodynamic configuration. A. During the Cambrian, the Gondwana margin is marked by the emplacement of calc-alkaline magmas attributed to an enriched mantle source above a subducting slab. The size of the Iapetus is about $2000-3000 \mathrm{~km}$ wide. B. During the Ordovician, the Avalonia and Armorica continental ribbons are separated from the Gondwana margin. The Rheic Ocean corresponds to the future Rheic suture exposed in southern Great Britain. The Medio-European Ocean corresponds to the Leptynite-Amphibolite Complex forming boudins and enclaves in high-grade nappes of the Moldanubian allochthonous terrane (see Fig. 3). The tholeitic to calc-alkaline signature of the LAC is interpreted as reflecting an emplacement of the magmatic protoliths in a back-arc or immature oceanic setting. Alkaline magmas intrusive in Ediacarian sedimentary sequences correspond to orthogneisses preserved in the LGU and PAU and are attributed to opening of a series of rifts leading to hyperextension of the Gondwana margin. These features are consistent with retreat of the southward plunging Iapetus slab that will eventually lead to tectonic accretion of Avalonia to the Laurussia craton.

mixing of mantle and crustal units. Tectonic-geodynamic models attributing the succession of eclogite and granulite facies metamorphism to oceanic subduction followed by continental collision (Matte, 1986; Girardeau et al., 1986; Dubuisson et al., 1989; Ledru et al., 1989; Lardeaux et al., 2001) provide an explanation for the HP metamorphic condition but do not account for the systematic incorporation of the LAC into the migmatitic UGU. Models invoking a vertical extrusion of the mantle into the partially molten granulitic lower crust account for the presence of mafic and ultramafic rocks into the migmatitic continental rocks but do not propose a driving force for such a process (Kusbach et al., 2012). A more appealing proposition is that pieces of suprasubduction mantle might be incorporated into the orogenic belt during relamination of orogenic crust by flow of partially molten crustal units decoupled from the downgoing slab (Lexa et al., 2011; Kusbach et al., 2015). Another option is that the association of remnants of an oceanic suture together with lithospheric mantle into granulite facies migmatitic gneisses, was achieved by mixing of subducted units into the mantle (O'Brien and Rötzler, 2003; Faure et al., 2008). In this latter scenario, granulite-facies partial melting of the UGU would be driven either by decompression of the UGU during syn-orogenic exhumation (Faure et al., 2008) or owing to thermal relaxation about $30 \mathrm{Ma}$ after subduction (O'Brien and Rötzler, 2003). We concur to the latter proposition as it will be developed in the next section.

\subsection{Middle Devonian to early Carboniferous syn-orogenic exhumation of the partially molten subducted crustal units with mantle enclaves}

The geological record of the middle Devonian to early Carboniferous period is marked by the association of HT eclogites and HP granulite-facies migmatites of the UGU. These are only present south of the Nort-sur-Erdre Fault in the Armorican Massif and of the Lalaye-Lubine Fault in the Vosges Massif (Fig. 1), which delineate the main suture south of the Armorica-Barrandia continental block (Faure et al., 1997). North of this suture, the inprint of Variscan metamorphism is absent or limited. The typical retrogression and transposition of the granulite facies mineral assemblage and foliation of the UGU into an amphibolite facies foliation records isothermal decompression caused by rapid exhumation (Pin and Vielzeuf, 1983; Dufour, 1985; Burg et al., 1989a, 1989b; Gardien et al., 1990; Mercier et al., 1991a, 1991b; Lardeaux et al., 2001; Faure et al., 2008) (Fig. 4). The position of the exhumed high-grade nappes relative to the Nort-surErde Fault and Lalaye-Lubine Fault implies that this suture was reworked as a steep syn-orogenic detachement allowing the exhumation of the continental units previously entrained in subduction and then decoupled from the slab (Figs. 18B and 18C). The inverted metamorphic gradient at the contact between the UGU and the LGU (Nicollet, 1978; Burg et al., 1984; Burg et al., 1989a, 1989b; Schulz et al., 2001) suggests 


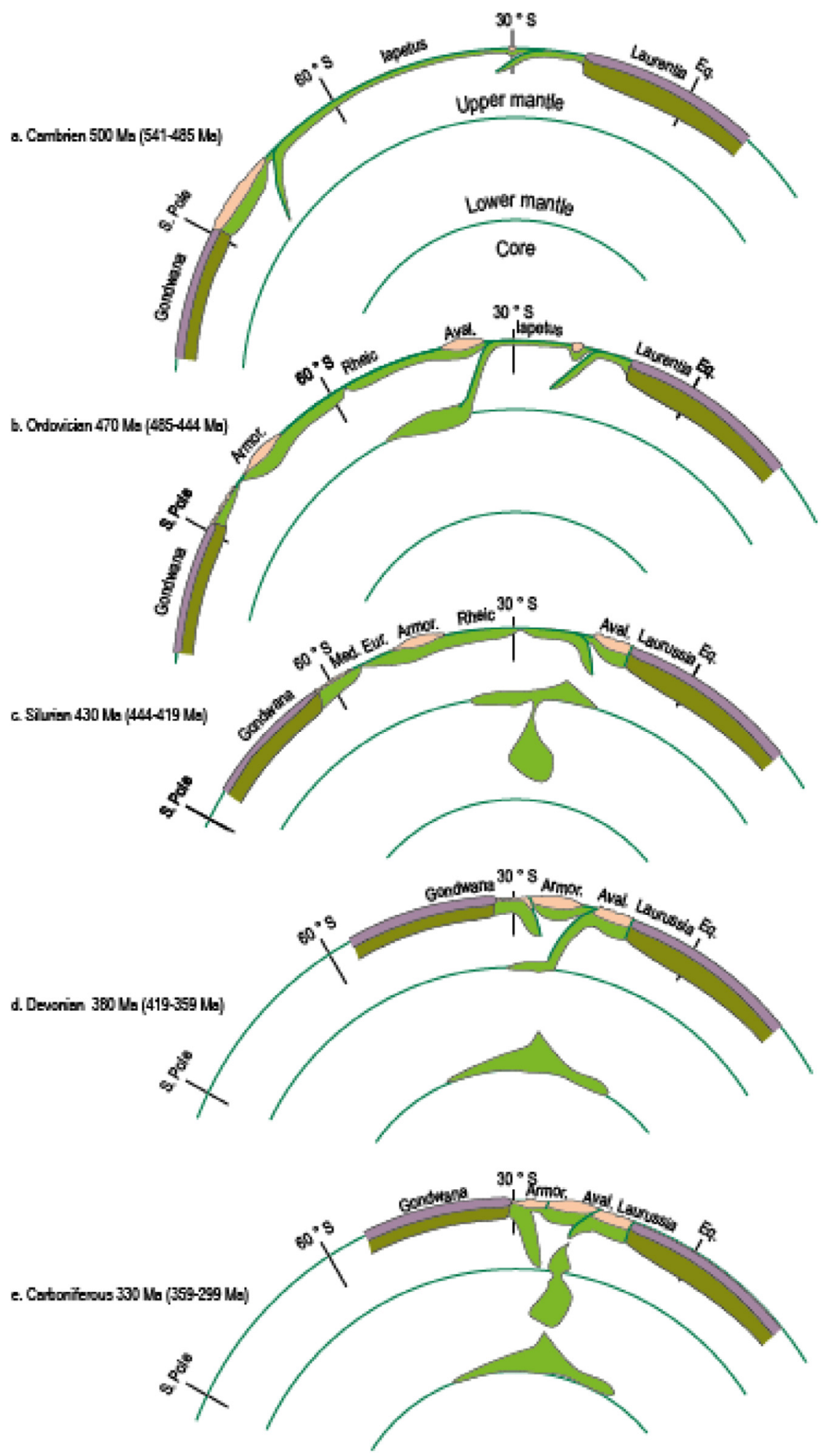

Fig. 17. Plate scale geodynamic reconstruction for the Paleozoic (modified after Domeier, 2016; Domeier and Torsvik, 2014; Matte, 2001). A. Cambrian $500 \mathrm{Ma}$ (541-485 Ma). The Gondwana margin is at the South Pole, Laurentia is at the Equator and the Iapetus Ocean is at least $3000 \mathrm{~km}$ wide. The Gondwana margin is an active plate boundary marked by subduction of the Iapetus. B. Ordovician $470 \mathrm{Ma}$ ( $485-444 \mathrm{Ma}$ ). The margin of Gondwana is marked by hyperextension resulting in the separation of Avalonia and Armorica and the opening of the Rheic and Medio-European Oceans. C. Silurian $430 \mathrm{Ma}$ (444-419 Ma). The Iapetus Ocean has closed and Avalonia has been tectonically accreted to Laurussia. The Rheic Ocean started to subduct beneath the margin of Laurussia and Medio-European Ocean, between Armorica and Gondwana is at its maximum width. D. Devonian $380 \mathrm{Ma}$ (419-359 Ma). Armorica is bounded by subduction zones with opposite vergence resulting in the formation of the Variscan belt. E. Carboniferous $330 \mathrm{Ma}$ (359-299 Ma). The Variscan orogenic front progresses from the hinterland to the foreland in association with slab retreat. 
that the exhumation of the UGU is associated with burial of the LGU. This is consistent with transposition of the granulite facies foliation of the UGU into an amphibolite facies synmigmatitic foliation (Forestier, 1961; Burg and Matte, 1978) and with the absence of HP/HT eclogitic relicts in the LGU. Thrusting of the UGU over the LGU is locally corroborated by kinematic data indicating a top-to-the SE sense of shear (Faure et al., 1979, 2009a; Burg et al., 1984). However, this contact is in many places reworked and retrogressed into a greenschist facies fabric associated with a top-to-the NW sense of shear attributed to regional extension leading to exhumation of the LGU and of the PAU (Faure et al., 1979, 2008, 2009a).

Available geochronological and stratigraphic data indicate that exhumation of the UGU started before the late Devonian with the emplacement of the northern nappe exposed in the Aigurande plateau, the Morvan area, and sampled in the Couy borehole (Costa and Maluski, 1988; Godard, 1990; Boutin and Montigny, 1993). The exhumation of the UGU forming the central and southern nappe (Limousin, Sioule-Combrailles, Livradois - Haut-Allier, Lyonnais) is bracketed between the late Devonian and the Visean and thus postdates the exhumation of the northern nappe (Pin and Lancelot, 1982; Melleton et al., 2009; Gardien et al., 2011; Do Couto et al., 2016; Chelle-Michou et al., 2017). Migmatitic paragneisses from the Limousin and the Sioule display a subhorizontal foliation bearing a NW-SE trending lineation mostly associated with top-to-the-NW kinematic criteria interpreted to accommodate syn-orogenic exhumation of the UGU (Bellot and Roig, 2007; Do Couto et al., 2016). In the Livradois, the foliation of the migmatites attributed to the UGU is steeplydipping and is associated with dextral top-to-the SE kinematic criteria interpreted to record extrusion of the UGU (Gardien et al., 2011; Vanderhaeghe et al., 2013). Such a mechanism of vertical extrusion for the formation of high-grade nappes is consistent with the interpretation of the Champtoceaux nappe, in the Armorican Massif, as a fold nappe (Ballèvre et al., 2009) and has also been proposed to account for the structure of the varied gneiss unit in the Vosges (Skrzypek et al., 2014) and the Bohemian Massif (Schulmann et al., 2014).

Several lines of reasoning suggest that the multiple nappes model is more coherent with the hyperextended margin model made of thinned continental blocks separated by small immature oceanic basins than with a pre-Variscan configuration characterized by a single, large oceanic domain between Gondwana and Armorica. First, the inverted metamorphic isograds, requiring limited thermal relaxation after underthrusting, fits better with a model considering a system of several small nappes with at most a few tens of kilometres of lateral expansion, rather than the case of a single, several hundred kilometres long nappe. Indeed, thermal-mechanical modelling of orogenic evolution indicates that inverted metamorphic/thermal gradients are not sustainable for more than about $100 \mathrm{~km}$ equivalent to about $10 \mathrm{Ma}$ with a convergence rate of $1 \mathrm{~cm} / \mathrm{yr}$ (Huerta et al., 1996; Henry et al., 1997; Vanderhaeghe et al., 2003). Moreover, the multiple nappes model predicts diachronous HP metamorphism, which seems to be confirmed by the currently available geochronological data. Finally, the absence of large volumes of calc-alkaline magmatism associated with subduction initiation and steady-state subduction further suggests that forced subduction of several hyper-extended basins is a more likely scenario than the spontaneous subduction intiation of a mature oceanic crust (see McCarthy et al., 2018).

Following this rationale, following other authors, we propose that the construction of the Variscan orogenic belt was achieved by tectonic accretion of continental units that were previously subducted and then decoupled from the downgoing slab (Faure et al., 1997, 2008; Lardeaux et al., 2001) rather than by continental collision and indentation and thickening of the overriding plate as proposed in early tectonic reconstructions (Matte, 1986; Franke, 1989; Ledru et al., 1989). Again, available geochronological data for the UGU and LAC are consistent with partial melting at highpressure (10-20 kbars) of paragneisses, orthogneisses and amphibolites c. 20 to $30 \mathrm{Ma}$ after subduction (Nicollet and Leyreloup, 1978; Duthou et al., 1981, 1994; Pin and Lancelot, 1982; Chelle-Michou et al., 2017). Although such data are scarce and of unequal robustness from a nappe to another, this time span is broadly consistent with that required for thermal relaxation after burial (England and Thompson, 1984; Vanderhaeghe et al., 2003). Following models advocated for the tectonic accretion of HP mafic-ultramafic rocks enclosed in migmatitic units (O'Brien and Rötzler, 2003; Labrousse et al., 2011; Gordon et al., 2016; Závada et al., 2018), we propose that partial melting of subducted units forming the protolith of the UGU triggered their mechanical decoupling from the slab. In this scenario, mafic and ultramafic enclaves would represent fragments of previously subducted oceanic crust and lithospheric mantle entrained by the buoyant and low-viscosity, partially molten rocks, on their way back towards the surface. This process corresponds to syn-orogenic exhumation by vertical extrusion of the partially molten nappes. According to this proposition, the UGU represents the part of the thinned continental margin that has been subducted and then decoupled from the downgoing slab, while the LGU represents the part of the former continental margin that was underthrusted beneath the UGU during its syn-orogenic exhumation. The age gradient for retrogression and cooling of the UGU, ranging from c. $385 \mathrm{Ma}$ in the north to c. $340 \mathrm{Ma}$ in the south, is consistent with progressive exhumation of nappes successively decoupled from a northvergent and southward-retreating subduction slab (Fig. 18). We defined here a northern, central and southern nappe but this proposition and the number of nappes and of repeated UGU/LGU alternations remains to be clarified. Another consequence of partial melting of subducted fertile continental units might be the percolation of felsic melts into the suprasubduction mantle wedge, contributing to its enrichment in incompatible elements. Such a process might explain the signature of mafic magmas emplaced during the Carboniferous, as described in the next section.

\subsection{Late Devonian exhumation of nappes in between retreating slabs}

The geological record of the late Devonian period (Figs. 11, $18 \mathrm{~B}$ and $18 \mathrm{C}$ ) is marked by a great diversity of information that is difficult to reconcile in a single geodynamic context. In the northern part of the French Massif Central, plutonic and volcanic rocks (ACG) exposed respectively in the Somme and 
Limousin regions have been interpreted as a continental magmatic arc (Pin and Paquette, 1997; Faure et al., 2008). The tholeiitic to calc-alkaline volcanic rocks of the Brévenne Unit have been attributed to a back-arc rift basin (Bébien, 1971; Pin and Lancelot, 1982; Sider and Ohnenstetter, 1986). Rocks of the same age and geochemical signatures exposed in the Central Bohemian Plutonic Complex have been interpreted as arc magmas originated in an Andean-type continental margin (Janousek and Holub, 1997; Janoušek et al., 2004; Schulmann et al., 2009). The positive $\varepsilon_{\mathrm{Nd}}$ of these magmatic rocks points to a dominant juvenile contribution (Fig. 13A). However, structural, metamorphic and geochronologic record demonstrate that the late Devonian is also marked by (1) the exhumation of the central nappe in the Limousin and Livradois (Bellot and Roig, 2007; Melleton et al., 2009; Gardien et al., 2011; Do Couto et al., 2016); and (2) the emplacement of cordierite-bearing peraluminous granite laccoliths (CPG) (Berthier et al., 1979; Pin and Paquette, 1997; Bertrand et al., 2001; Cartannaz, 2006; Gébelin et al., 2009). The crustderived Guéret-type plutons formed through melting of dominantly metasedimentary sources, possibly with the contribution of a mafic igneous lower crust (Downes and Duthou, 1988; Downes et al., 1997). These data imply that the end of opening of the Brévenne rift and the construction of the Morvan continental arc are coeval with partial melting of subducted continental units. Furthermore, this activity is contemporaneous to deposition of detrital sediments and carbonates in the underfilled southern foreland basin at the front of a propagating thrust system, currently exposed in the Pyrénées (Franke and Engel, 1986; Souquet et al., 2003).

To the south of Armorica, geochronological data obtained on blueschists exposed in the Ile de Groix and on lowtemperature eclogites at the base of the Champtoceaux nappe indicate that high-pressure metamorphism attributed to subduction occurred at about 370-360 Ma (Bosse et al., 2000, 2005; Paquette et al., 2017). North of the Nort sur Erdre fault, the Saint Georges sur Loire unit, a late Silurian to early Devonian back-arc basin, affected by blueschist facies metamorphism, has also potentially been subducted at this time (Ledru et al., 1986; Cartier et al., 2001). Mid to late Devonian subduction, but with a southward dip, is likewise recorded north of the Medio-European suture, in the SaxoThuringian terrane to the north of the Vosges and of the Bohemian Massif (Schulmann et al., 2014; Skrzypek et al., 2014). In the Vosges Massif the "ligne des Klippes" represents an immature oceanic basin opened during the late Devonian and inverted in the Lower Carboniferous (Skrzypek et al., 2012). North of Armorica, in South West England, the Lizard suture represents an early Devonian immature oceanic domain obducted during the early Carboniferous (Floyd and Leveridge, 1987; Clark et al., 1998; Shail and Leveridge, 2009).

Accordingly, late Devonian extension in the internal zone of the Variscan belt occurred in an overall context of plate convergence as implied by subduction/exhumation of nappes, foreland propagation of deformation and deposition of clastic sediments. Therefore, two geodynamic scenari are evoked to account for this extension, namely (i) opening of a back-arc associated with northward subduction of the Medio European Ocean being contemporary with the southward subduction of the Rheic Ocean followed by continental collision (monocyclic model, Matte, 1986; Ledru et al., 1989; Lardeaux et al.,
2001), or (ii) renewed extension of the Eo-Variscan orogenic belt associated with southward subduction of the Rheic Ocean after closure of the Medio European Ocean by northward subduction (polycyclic model, (Pin, 1990; Leloix et al., 1999; Faure et al., 1997, 2009a; Lardeaux, 2014; Lardeaux et al., 2014). The cooling ages obtained on the UGU of the Aigurande plateau indicates that at least some of the highgrade nappes were exhumed to the surface before late Devonian rifting and emplacement of the Brévenne volcanics, which is more consistent with the polycyclic model.

Alternatively, to resolve the apparent discrepancy between an overall context of plate convergence and local extension, we propose that late Devonian geodynamics was characterized by convergence accommodated by subduction but also by retreat of the northern (Rheic) and southern (Medio-European) slabs. This explains simultaneous closure of immature oceanic basins entrained in subduction, tectonic accretion of ribbon-shaped terranes and extension of the upper plate. Hence, the exhumation of previously subducted continental units might have occurred without substantial erosion owing to the opening of space toward the surface in between the retreating slabs as envisioned in the conceptual models of Vanderhaeghe and Duchêne (2010). In this scenario, the top to the NW kinematic criteria marking the contact between the Brévenne Unit and the UGU of the Monts du Lyonnais might have accommodated the last stage of syn-orogenic exhumation of the high-grade nappe as proposed for the exhumation of the UGU in the Limousin at the same period (Bellot and Roig, 2007).

However, this model does not fully account for lateral variations of the tectonic context, evidenced by exhumation of nappes and emplacement of peraluminous granites in the western French Massif Central coeval with opening of a continental to oceanic rift in its eastern part. Two directions are proposed for future reflexion. The first one would be to consider a context of oblique plate convergence, which might allow for opening of pull-apart basins along releasing bends and concomitant burial and exhumation of tectonic units along restraining bends. The second one would be to infer differential retreat between the western and eastern side of the French Massif Central that might have been accommodated by a precursor of the Sillon Houiller strike-slip fault (Fig. 3). Slab retreat potentially controls the tectonic-magmatic geological history of the French Massif Central throughout the Carboniferous as described in the following sections.

\subsection{Carboniferous (c. 345-310 Ma) building of an orogenic plateau by lateral flow of the partially molten orogenic root}

The Carboniferous (345-310 Ma) geological record of the FMC is marked in the northern part by E-W to NW-SE trending regional-scale dextral strike-slip shear zones and orogen-parallel stretching localizing the emplacement of mantle and crust-derived magmas and in the southern part by thrusts and folds in the Cévennes, Albigeois and Montagne Noire, coeval with deposition of clastic sediments in the foreland (Figs. 1, 3, 12, 18D) (Arthaud and Matte, 1975; Engel, 1984; Feist and Galtier, 1985; Arnaud and Burg, 1993; Faure et al., 1999). The strike-slip shear zones, exemplified in the Limousin (Faure and Pons, 1991; Mollier and Bouchez, 1982; Roig and Faure, 2000; Gébelin et al., 2007, 2009), in the Forez (Barbarin and Belin, 1982), in the 
Livradois (Gardien et al., 2011; Vanderhaeghe et al., 2013), and in the Lyonnais (Lardeaux and Dufour, 1987), merge to the northwest with the South Armorican shear zone (Lerouge and Quenardel, 1988; Carlier De Veslud et al., 2004; Gébelin et al., 2007; Rolin et al., 2009, 2014). As presented above, these strikeslip shear zones have been interpreted either to record a period of transpression (Lardeaux and Dufour, 1987; Gébelin et al., 2007) or to reflect the transition from collision to orogen-parallel extension (Ledru and Autran, 1987; Faure et al., 1993, 2009b; Roig and Faure, 2000).

After a 10 Ma gap from c. 355 to c. $345 \mathrm{Ma}$, magmatism proceeded with the emplacement of plutonic and volcanic rocks throughout the middle Carboniferous (Fig. 12). In Section 3.4, following previous authors (Williamson et al., 1996, 1997; Barbey et al., 2015; Laurent et al., 2017; Moyen et al., 2017), MPG and CPG (and their volcanic counterparts) are proposed to derive from a mixed crustal source comprising ortho- and paragneisses from the LGU. Partial melting of the orogenic root at this time is documented by MP migmatites dated at c. $315 \mathrm{Ma}$ underlying the Millevaches granitic laccolith (Gébelin et al., 2009) and by MP migmatites mantling the Velay dome with ages ranging from c. 330 to c. $315 \mathrm{Ma}$ (Mougeot et al., 1997; Cocherie et al., 2005; Bé Mézémé et al., 2006). Although volumetrically less abundant, mantle-derived magmatism is expressed almost exclusively in the East Massif Central (only a few occurences are described in Limousin) by the presence of widespread vaugnerites, forming decimeter- to kilometer-sized bodies intimately associated with the granites and migmatites. The dual geochemical character of vaugnerites $\left(\right.$ low $\mathrm{SiO}_{2}$, high $\mathrm{Mg} \#$ together with elevated K, LILE and LREE contents), as well as their Sr-Nd$\mathrm{Pb}-\mathrm{Hf}$ isotope signatures (Turpin et al., 1988; Couzinié et al., 2016), is consistent with partial melting of a lithospheric mantle that was previously enriched in incompatible elements (Sabatier, 1991; Solgadi et al., 2007; von Raumer et al., 2014 Couzinié et al., 2016). The variety of the geochemical signatures of some granitoids and the fact that they contain micromafic enclaves indicate a mixture of crustal-derived and mantle-derived magmas, as illustrated in the Livradois (Solgadi et al., 2007). This model would be particularly relevant to explain the origin of the compositionally intermediate KCG and, to a lesser extent CPG. The Margeride granite, for example, shows an intermediate signature, interpreted as reflecting interaction with mafic melts (Williamson et al., 1992; Laurent et al., 2017). Collectively, granites exposed in the eastern French Massif Central show the implication of different sources that are progressively affected by partial melting as the temperature of the orogenic root increases (Fig. 14). Geochronological data indicate that (i) granites and vaugnerites emplaced together from c. 340 to c. $300 \mathrm{Ma}$ and (ii) there is a progressive younging of $\mathrm{U}-\mathrm{Pb}$ emplacement ages of both granites and vaugnerites from the North (Forez, Lyonnais) to the South (Cévennes) in the considered time period, pointing to the southward migration of a lithospheric-scale thermal anomaly resulting in both crustand mantle melting (Laurent et al., 2017).

In the North-Eastern Massif Central, the extrusive equivalents of the granitoids record a drastic shift in composition during the middle Carboniferous. They change from mafic, low to medium-K calc-alkaline to felsic and high $\mathrm{K}$ (potassic rhyolites, and associated microgranites), broadly similar to MPG in composition. These rhyolites are middle to upper Visean in age as constrained by a U-Pb zircon age of $336.9 \pm 3.2 \mathrm{Ma}$ (Cartannaz et al., 2007a), identical within uncertainty to the age of the underlying granitoids (Laurent et al., 2017). Moreover, both the early, and the middle Carboniferous magmatic rocks do include some mantle-related components, with nevertheless clear differences in the nature of the mantle component between these two periods (Fig. 14A). Up to the early Carboniferous (before c. 345-340 Ma), the isotopic composition of the mantle-derived magmatic rocks (late Devonian Brévenne and lower Carboniferous series) are on the mantle array, consistent with an asthenospheric mantle source. On the other hand, the middle (and late) Carboniferous mantle-derived magmatic rocks (vaugnerites and lamprophyres) are shifted towards "crustal" compositions, reflecting the growing influence of a recycled crustal component in the mantle below the French Massif Central (Fig. 13). A similar and coeval evolution is described in the Bohemian Massif (Janousek and Holub, 1997; Janoušek et al., 2004). In the French Massif Central, there is not only a temporal evolution, but also a spatial distribution of mantle sources. While the enriched mantle is centered on the Velay complex, the non-enriched mantle domain is located in the Northern part of the region (Beaujolais and Morvan). Similarly, different mantle compositions are still featured today in mantle xenolith from Cenozoic volcanoes (Lenoir et al., 2000), displaying a comparable spatial distribution. Furthermore, the volumetrically more abundant Cenozoic magmatism occurs in the domain where the mantle is more enriched (and probably more fertile).

The preservation of platform carbonates of Visean age in the northern part of the French Massif Central and around the Montagne Noire, indicates that these regions were below sea level at this time. Other sedimentary sequences of this period corresponds to the erosion products of subcontemporaneous volcanics and plutonics traping organic matter in continental basins delimited by strike-slip shear zones or normal faults (Bertaux et al., 1993; Bruguier et al., 1998; Thiéry et al., 2009).

In order to reconcile all observations, we propose that exhumation of migmatites along strike-slip shear zones coeval with foreland propagation of the deformation front correspond to growth of an orogenic plateau by lateral flow of the partially molten orogenic root in a context of plate convergence associated with southward slab retreat (Figs. 17 and 18D). This plateau spreads from south of the Brévenne region to north of the Montagne Noire as constrained by the deposition of plateform carbonates. In this model, the partially molten orogenic root also flows toward the north beneath the former late Devonian Brévenne rift basin. Such horizontal flow, already proposed for the Vosges (Skrzypek et al., 2014) and the Bohemian Massifs (Lexa et al., 2011; Schulmann et al., 2014; Kusbach et al., 2015), explains the voluminous granitic magmatism observed at that time. The systematic occurrence of vaugnerites along with granitic magmas point to mantle melting that might be caused by decompression as a consequence of slab retreat. 


\subsection{Late Carboniferous to Permian (c. 305-295 Ma) gravitational collapse and exhumation of the partially molten root of the Variscan orogenic belt}

The late Carboniferous (Figs. 15 and 18E) is marked by regional scale extension of the Variscan belt of Western Europe (Ménard and Molnar, 1988), which is particularly illustrated in the French Massif Central by the activation of low-angle detachments (Malavieille et al., 1990; Van Den Driessche and Brun, 1992; Burg et al., 1993; Faure, 1995; Gardien et al., 1997; Vanderhaeghe et al., 1999; Bouilhol et al., 2006) controlling the exhumation of migmatites in the core of domes such as the Velay in the central-east French Massif Central (Dupraz and Didier, 1988; Burg and Vanderhaeghe, 1993; Ledru et al., 2001) and the Montagne Noire in the southern French Massif Central (Gèze, 1949; Nicolas et al., 1977; Echtler and Malavieille, 1990; Van Den Driessche and Brun, 1992; Rabin et al., 2015; Trap et al., 2017) (Fig. 3).

The HT/LP metamorphic conditions recorded by the migmatites coring the Velay and Montagne Noire domes and by the lower crustal granulites have been classically interpreted in terms of a sudden increase in temperature at the end of the Carboniferous (Marignac et al., 1980; Dupraz and Didier, 1988; Lardeaux et al., 2001; Ledru et al., 2001; Couzinié et al., 2014; Barbey et al., 2015). However, such a catastrophic event is not required by the data. Indeed, as discussed in the previous section, (i) the oldest ages obtained on migmatites in the Limousin and around the Velay and Montagne Noire domes, and (ii) the coeval emplacement of granitic plutons and vaugnerites indicates that the crust and the mantle were already partially molten as early as $340 \mathrm{Ma}$ ago and remained so throughout the Carboniferous (Laurent et al., 2017; Vanderhaeghe et al., 1999). A similar time range has been proposed for the duration of the partial melting event in the Variscan crustal segment exposed in the Ivrea-Verbano Zone (Guergouz et al., 2018) but also for the root of the Grenville orogenic belt (Turlin et al., 2018). The continuous magma extraction from a partially molten source at depth results in the emplacement of granitic plutons (CPG, MPG) at higher structural level in combination with the entrainment of source material, which fully explains their chemical characteristics (Villaros et al., 2018). Final crystallization of migmatites is constrained by the ages of late-migmatitic dikes at c. $297 \mathrm{Ma}$ in the Velay (Montel et al., 2002; Didier et al., 2013) and by the emplacement of a syntectonic granite at c. $294 \mathrm{Ma}$ in the Montagne Noire (Poilvet et al., 2011).

The size of the Velay and Montagne Noire domes, i.e. several tens of $\mathrm{km}$ in diameter, indicates that they are crustalscale features (Van Den Driessche and Brun, 1992; Burg and Vanderhaeghe, 1993; Ledru et al., 2001). This view of a pervasively partially molten orogenic root is corroborated by the diversity of the protoliths (orthogneisses, paragneisses, amphibolites...) that have molten to form the migmatites (Downes and Duthou, 1988; Williamson et al., 1992; Downes et al., 1997; Ledru et al., 2001; Barbey et al., 2015; Rabin et al., 2015). Moreover, the fact that the domes are circumscribed by the foliation of the host paragneisses and orthogneisses (Lagarde et al., 1994; Echtler and Malavieille, 1990; Mattauer et al., 1996) and by the syn-melting foliation of the migmatites (Burg and Vanderhaeghe, 1993; Ledru et al., 2001; Rabin et al., 2015) indicates that the migmatites correspond to a mechanically coherent partially molten body. In the Velay, the synmigmatitic foliation delineates subdomes of about $10-20 \mathrm{~km}$ in diameter and bears a radially distributed HT mineral lineation pointing to the role of gravitational instabilities (Ledru et al., 2001; Vanderhaeghe, 2009). Such subdomes have been described in Naxos Aegean domain and interpreted as reflecting crustal-scale convection (Kruckenberg et al., 2011; Vanderhaeghe et al., 2018). In the Montagne Noire, migmatites in the core of the dome display a prolate finite strain ellipsoid indicative of constriction with a subhorizontal long axis parallel to the axis of the elliptical shape dome, which is coeval with exhumation of the core of the dome (Echtler and Malavieille, 1990; Van Den Driessche and Brun, 1992; Mattauer et al., 1996; Aerden and Malavieille, 1999; Charles et al., 2009; Rabin et al., 2015). Following this rationale, the development of crustal-scale migmatite domes at 305-295 Ma marks the time at which the long-lived, partially molten lower-middle crust cooled rapidly as a consequence of rapid exhumation owing to gravitational collapse. If crustal thinning was faster than thermal relaxation, isothermal decompression of the migmatites would result in an increase of the geothermal gradient as observed in the E-FMC (Montel et al., 1992; Barbey et al., 1999, 2015; Ledru et al., 2001).

To explain the protracted melting of the root of the Variscan orogenic crust, one may invoke the effects of an increase in radioactive heat production of the thickened crust, combined with the increase in mantle heat flux owing to the southwards removal of the lithospheric mantle slab underneath the FMC. Coeval crustal thickening and lithospheric mantle thinning is the best case scenario to produce a high geothermal gradient in the continental crust (Vanderhaeghe and Duchêne, 2010) that might last for several tens of Myrs (Ueda et al., 2012). This model is also supported by the nature and spatial/temporal evolution of granitoid and vaugnerite magmatism (Moyen et al., 2017; Laurent et al., 2017). In addition to the thermal input at the base of the orogenic crust, partial melting might also be enhanced by exhumation, as dehydration melting reactions are crossed during decompression (Thompson and Connolly, 1995).

In the external zone of the Variscan belt, specifically in the Montagne Noire area, migmatites are present beneath and deform a metasedimentary sequence affected by recumbent folds and low-grade metamorphism. This is paradoxal as this scheme does not match the classical model of thermal relaxation after nappe stacking (Franke et al., 2011). Moreover, the deposition age of the protolith of part of the metasedimentary sequence (Visean to Namurian) overlaps with the geochronological record of HT/LP metamorphism and granitic intrusion, spreading from c. 330 to c. $300 \mathrm{Ma}$. In order to resolve this paradox, we propose that sediment deposition, HT/LP metamorphism and granite emplacement were indeed coeval but occurred in laterally remote units that were subsequently juxtaposed owing to lateral horizontal flow of the partially molten orogenic root beneath the sedimentary rocks and their upper crustal basement (Figs. 18E and 19). In this scenario, the migmatites coring the Montagne Noire dome represent partially molten rocks that were located beneath the orogenic plateau since the early Carboniferous and have flown laterally from the internal to the external zone in the late Carboniferous. The migmatites and associated granites were then exhumed, cooled and juxtaposed to the metasedimentary 

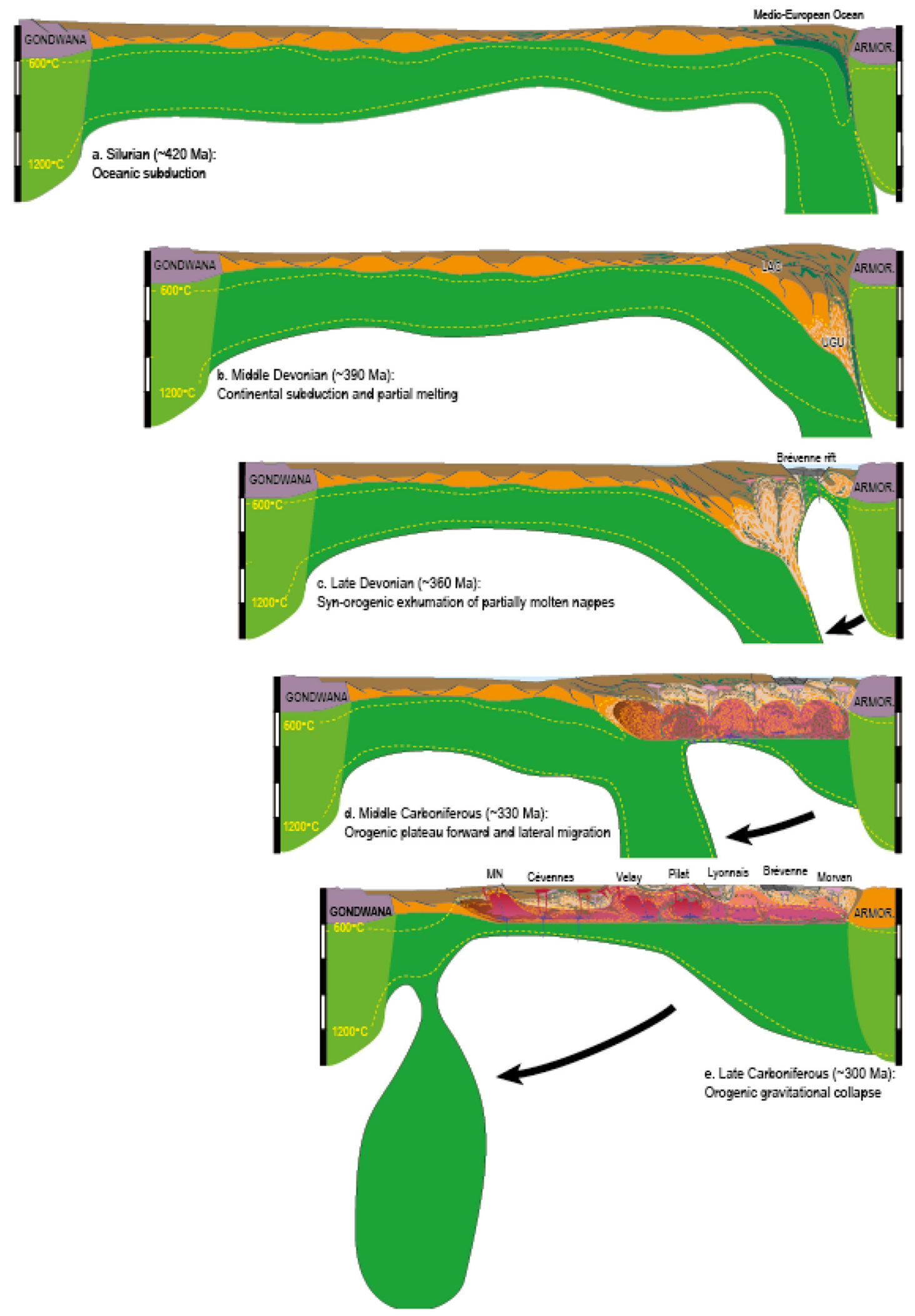

Fig. 18. Geodynamic-tectonic model of the Variscan bel exposed in the French Massif Central. A. Silurian (c. 420 Ma) subduction of the MedioEuropean Ocean. B. Middle Devonian (c. $385 \mathrm{Ma}$ ) subduction and partial melting of the hyper-extended northern continental margin of the Gondwana craton. C. Late Devonian (c. $365 \mathrm{Ma}$ ) slab retreat, opening of the Brévenne rift and syn-orogenic exhumation of high-grade partially molten nappes. D. Lower Carboniferous (c. $330 \mathrm{Ma}$ ) development of an orogenic plateau by lateral flow of partially molten orogenic root in a context of plate convergence and southward slab retreat. E. Late Carboniferous (c. $300 \mathrm{Ma}$ ) gravitational collapse of the Variscan belt in a context of southward slab delamination accommodated by lateral and upward flow of the partially molten orogenic root concomitant with brittle extension of the upper crust. 


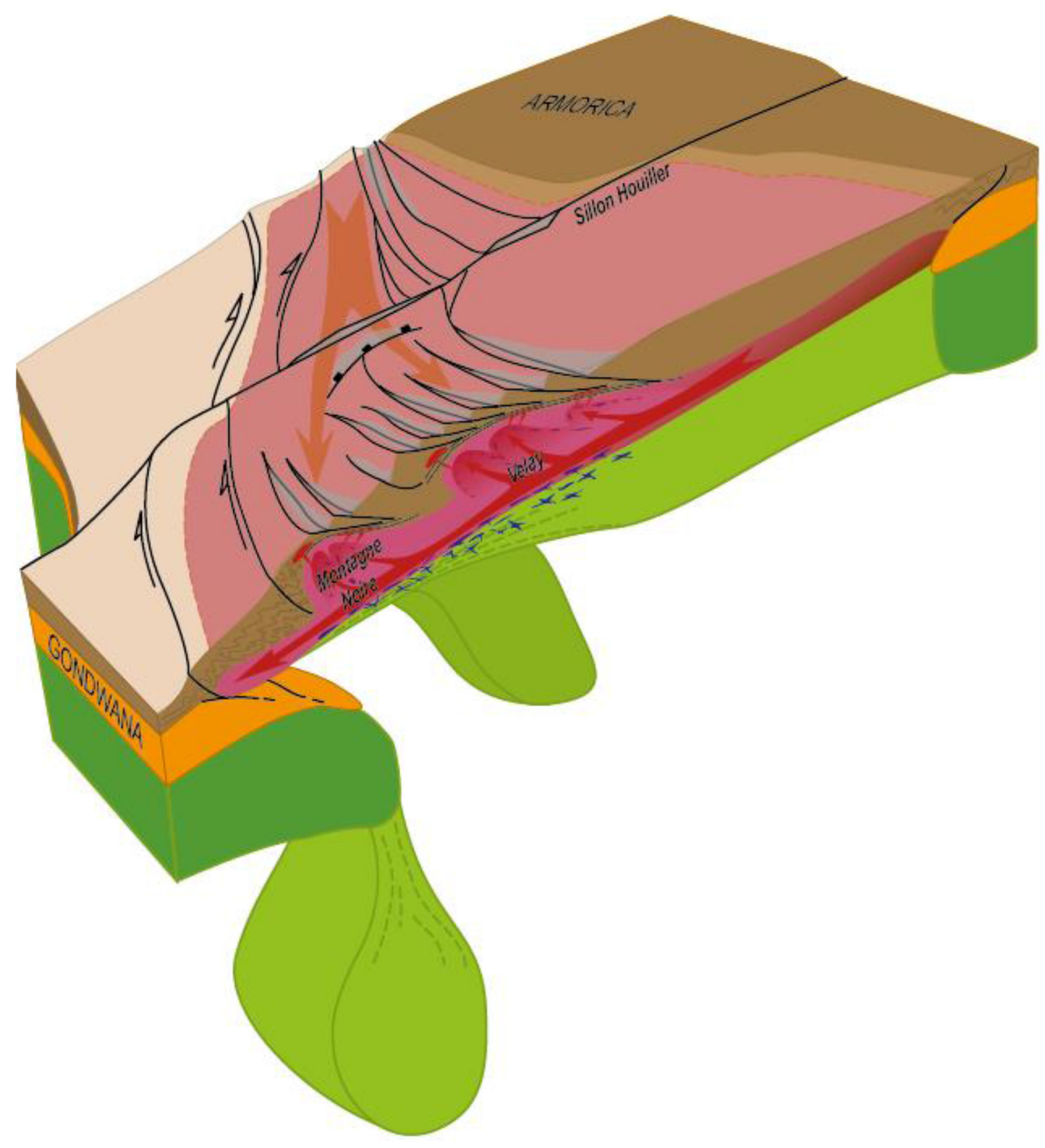

Fig. 19. 3D model for the late Carboniferous crustal and lithospheric scale structure of the Variscan belt beneath the French Massif Central. Gravitational collapse is accommodated by (i) lateral flow of the partially molten orogenic root from the western to the eastern side of the French Massif Central and from the internal to the external zone toward the south, and (ii) upward flow to form migmatite domes within Metamorphic Core Complexes. The Sillon Houiller accommodates differential slab retreat between the eastern and western parts of the French Massif Central.

nappes along a detachment. The Variscan basement exposed in the Axial Zone of the Pyrenees and in the North Pyrenean Massifs displays similar geological features (de Saint Blanquat, 1993; Gleizes et al., 1997; Cochelin et al., 2017) and the partially molten orogenic root might have flown toward the foreland beneath the current day Pyrenees providing an explanation for their peculiar Carboniferous-Permian structural and metamorphic record.

Comparison between the eastern and the western part of the FMC shows that large, late Carboniferous migmatite domes are only exposed in the eastern part of the FMC, which points to the Sillon Houiller as a major tectonic divide between these two parts of the FMC, at least during the late orogenic tectonic evolution. The Sillon Houiller corresponds to a subvertical sinistral strike-slip shear zone (Grolier and Letourneur, 1968; Arthaud and Matte, 1975) cross-cuting the Lower to Middle Carboniferous transcurrent strike-slip shear zones. It is in places sealed by Visean volcanics, and localizes the deposition of late Carboniferous to Permian clastic sediments accompanied with the emplacement of rhyolite at the onset of extension (Bonijoly and Castaing, 1984; Joly et al., 2008, 2009; Lapierre et al., 2008; Thiéry et al., 2009). Scarce U-Pb data indicate an onset of deposition in some basins as early as $330 \mathrm{Ma}$ (Bosmoreau and Decazeville Basins), but most ash beds yield 
ages of $300-295 \mathrm{Ma}$ that constrain a predominance of syntectonic intramontane basins (Jaujac, Bosmoreau, Alès, Bertholène, Graissessac and Roujan-Neffies basins) during the late Carboniferous (Bruguier et al., 1998, 2003). In the Livradois, cooling of the migmatites and granites is recorded by argon thermochronology on micas and K-feldspar between 307 and $300 \mathrm{Ma}$. It is associated with exhumation along a topto the west low-angle detachment that controls the deposition of coal-bearing sediments in the Brassac basin (Gardien et al., 2011; Vanderhaeghe et al., 2013). The discordant contact of these deposits with the LGU (locally migmatitic) and UGU attests that these metamorphic units reached surface exposure at the end of Carboniferous and that exhumation and crystallization of the partially molten orogenic crust and of crustal melts was essentially terminated by $295 \mathrm{Ma}$.

In the western Massif Central, this period is marked by ductile-brittle detachments such as the Argentat fault that also accommodate a component of strike-slip displacement (Bellot and Roig, 2007). Accordingly, the activity of the Sillon Houiller straddles the transition from the orogenic plateau development to gravitational collapse of the Variscan belt. The limited lateral offset of the Sillon Houiller compared to its the length is consistent with its role as a transfer fault accommodating a larger amount of N-S extension in the eastern part of the French Massif Central relative to the western part (Burg et al., 1990). The presence of migmatite domes solely in the eastern part of the French Massif Central is consistent with this model. Currently, except for a slight variation beneath the Cenozoic rift, the continental crust displays a constant thickness of c. $30 \mathrm{~km}$ on both sides of the Sillon Houiller (Ziegler and Dèzes, 2006). This suggests that, at the time of orogenic gravitational collapse, the larger amount of surface extension in the eastern French Massif Central was compensated in the orogenic root by flow of the partially molten rocks from the northern and western French Massif Central toward the Velay and Montagne Noire dome in the southeastern part of the French Massif Central. Moreover, the presence of migmatites in the Montagne Noire and in the Pyrenees, beneath the foreland sedimentary sequence affected by recumbent folds and low-grade to HT/LP metamorphism, also suggests that the partially molten orogenic root has flown toward the foreland. This model provides a potential explanation for the enigmatic high geothermal gradient identified in the external zone and for propagation of crustal thickening in the foreland beneath supracrustal rocks. Our model is also compatible with the shallow northward plunge $\left(0-30^{\circ}\right)$ of the mineral and stretching lineation displayed along the Sillon Houiller (Grolier and Letourneur, 1968; Bonijoly and Castaing, 1984).

The P-T-t record of the lower crust documented by felsic and mafic granulitic xenoliths with a maximum pressure of $14 \mathrm{kbar}$ and a temperature of $900{ }^{\circ} \mathrm{C}$ followed by near isothermal decompression (Leyreloup, 1974; Montel, 1985; Downes and Leyreloup, 1986) is consistent with a hot and thick orogenic crust that has then been affected by thinning. $\mathrm{U}-\mathrm{Pb}$ ages on zircon from the granulites from 320 to $280 \mathrm{Ma}$ cover the transition from crustal thickening to gravitational collapse (Downes and Leyreloup, 1986; Costa and Rey, 1995). The geochemical characteristics of the granulites suggest that they represent a mixture of (i) resisters (rocks that were not prone to melt), (ii) solid residues after melt extraction, (iii) cumulates (iv) and residual melts (Dupuy et al., 1979; Pin and Vielzeuf, 1983; Vielzeuf et al., 1990; Downes et al., 1997), which is complementary to the evidences for crustal-derived magmas emplaced at higher structural levels. Such features are also identified in exposed sections of the Variscan lower crust in the Ivrea Zone (Percival, 1992; Barboza et al., 1999; Bea and Montero, 1999; Schaltegger and Gebauer, 1999; Guergouz et al., 2018) or in Calabria (Schenk, 1980, 1981, 1989).

\subsection{Pertinence of the proposed geodynamic-tectonic model compared to physical modelling of the dynamics of orogenic belts}

In this section, we assess the significance of the geological record of rocks forming the Variscan belt exposed in the French Massif Central in terms of the thermal-mechanical evolution of orogenic belts as investigated by physical modelling.

Eclogites, which are the oldest metamorphic rocks identified in the French Massif Central, and are present at the highest structural level of the nappe pile, have recorded HP/ LT conditions. Such conditions imply burial at more than $30 \mathrm{~km}$ depth and more rapidely than the effect of thermal diffusion, typically a subduction rate of more than $1 \mathrm{~cm} / \mathrm{yr}$ (Huerta et al., 1996; Henry et al., 1997).

modelling of the thermal evolution of orogenic belts has shown that a time delay of 20 to 30 Myrs after crustal thickening is required for thermal diffusion and heat production through natural decay of radioactive isotopes to lead to significant partial melting of the orogenic root (England and Thompson, 1984; Thompson and Connolly, 1995). This 20 to 30 Myrs gap is consistent with the geochronological record of HT eclogites and granulites preserved in the UGU. In turn, the thermal impact of removal of the lithospheric mantle root is more rapid and dramatic in terms of increase in temperature in the crust (Houseman et al., 1981; Arnold et al., 2001). Thinning of the lithospheric mantle is so efficient that it has been proposed as a mechanism to account for HT/LP metamorphism in back-arc basins marked by a relatively thin crust (Collins, 2002). In the case of a convergent plate boundary marked by slab retreat and tectonic accretion, both the radioactive heat production and the mantle heat flux are increased concomitantly, which is the most favorable scenario for a hot orogenic root (Sandiford and Powell, 1990; Vanderhaeghe and Duchêne, 2010; Arnold et al., 2001). In such a case, thermal relaxation after removal of the lithospheric mantle occurs over about 100 Myrs (Ueda et al., 2012), which is roughly the duration of HT metamorphism and magmatism invoked in the geodynamictectonic model presented in this paper.

Exhumation of rocks entrained in subduction entails mechanical decoupling of these rocks from the downgoing slab, which in turns indicates that their buoyancy reached their mechanical strength (Chemenda et al., 1996; Escher and Beaumont, 1997; Warren et al., 2008). In turn, partial melting might be particularly efficient in decreasing the strength of buried rocks and thus favouring their decoupling from the downgoing slab and their exhumation.

The presence of a low-viscosity orogenic root is causing horizontal flow of the thickened crust (Artyushkov, 1973; Molnar and Lyon-Caen, 1988; Bird, 1991; Royden, 1996). 
This horizontal flow, driven by the gravity force associated with lateral variations of the weight of the crustal column, occurs preferentially toward a free boundary or a mechanically weak zone. In the case of an advancing plate boundary, i.e. indentation, horizontal flow occurs preferentially laterally and is associated with the activation of strike-slip shear zones (Royden, 1997; Cagnard et al., 2006). The low-viscosity layer might also flow in the direction of convergence, toward the foreland (Henk, 2000; Vanderhaeghe et al., 2003). The presence of a low-viscosity layer also impedes the maintenance of an irregular topographic surface (Artyushkov, 1973), which leads to the formation of an orogenic plateau (Molnar et al., 1993; Vanderhaeghe et al., 2003). If the zone of weak crust is maintained along its boundaries by stronger crustal sections, the orogenic plateau might be maintained (Vanderhaeghe et al., 2003; Cook and Royden, 2008). In the contrary, horizontal flow of the low-viscosity orogenic root will lead to redistribution of the orogenic crust until total decay of the gravity force (Rey et al., 2001). The style of extension is controlled by the rheology of the crust and thus its temperature (Buck, 1991; Rey et al., 2009).

Given its low density and low viscosity, a partially molten orogenic root is susceptible to develop diapiric RayleighTaylor instabilities (Ramberg, 1968; Talbot, 1979; Perchuk et al., 1992; Weinberg and Schmeling, 1992; Cruden et al., 1995) and even convective instabilities (Weinberg, 1997; Vanderhaeghe et al., 2018).

\section{Conclusion}

The structural, petrological, geochemical and geochronological record of the French Massif Central provides an archive of the thermal-mechanical evolution of the Variscan belt in Western Europe and documents the impact of partial melting and magmatism during orogenic evolution, as summarized in the following and in Figures 18 and 19.

The pre-Variscan paleogeography (Figs. 16 and 17) is marked by hyper-extension of the northern margin of the Gondwana supercontinent, evidenced by the coeval emplacement of alkaline granitoids and of tholeiitic to calc-alkaline bimodal mafic-felsic magmas of the Leptynite Amphibolite Complex during Ordovician times (485-460 Ma). This setting is particularly favorable for trapping of voluminous detrital sediments and the emplacement of alkaline magmas that might represent the protoliths of the main portion of the metagreywackes, metapelites and orthogneisses forming the UGU, MAU, LGU and PAU.

The presence of HT eclogite facies mafic and ultramafic enclaves of the Leptynite Amphibolite Complex into the migmatitic HP granulites of the UGU indicates subduction of the immature oceanic crust (Fig. 18A) together with continental ribbons (Fig. 18B). The 20-30 Ma difference in age between the eclogite-facies metamorphism recorded by the LAC corresponds to the time required for thermal relaxation and partial melting. Partial melting potentially triggered decoupling of the UGU from the downgoing slab allowing for the syn-orogenic exhumation of the partially molten UGU entraining pieces of mafic and ultramafic rocks forming the LAC and representing previously subducted oceanic lithosphere and/or part of the suprasubduction mantle. The percolation into the suprasubduction mantle of felsic melt segregated from the partially molten UGU would have possibly contributed to its enrichment in HFSE, REE and LILE required to form the source of the later vaugnerites.

During the Devonian-Carboniferous transition, opening of a rift in the internal zone of the Variscan belt is accompanied by the emplacement of the c. $360 \mathrm{Ma}$ ACG and low-K calcalkaline to tholeiitic magmas of the Brévenne Unit and Limousin tonalitic line. This is coeval with thrust propagation in the external zone and deposition of detrital sediments in the foreland that we tentatively attribute to the outward propagation of the orogenic belt in a context of slab retreat (Fig. 18C). Such a context might have facilitated syn-orogenic exhumation of the buoyant and low-viscosity partially molten felsic units previously dragged with the subducting slab.

Regional scale transcurrent shear zones and foreland propagation of thrusts accommodate the development of an orogenic plateau by gravity-driven lateral flow of the partially molten orogenic root, owing to a major Carboniferous thermal anomaly of lithospheric extent. This is indeed associated with high-temperature/medium-pressure metamorphism and the emplacement of syntectonic plutons from 345 to $310 \mathrm{Ma}$ (Fig. 18D). The diversity of the geochemical signatures of the magmatic rocks encompassing MPG, CPG and their volcanic equivalents, $\mathrm{KCG}$ and $\mathrm{Mg}-\mathrm{K}$ vaugnerites indicates a contribution of both the crust and the mantle. The latter along with the southward younger emplacement ages of these magmatic rocks is consistent with progressive retreat toward the south of the northward plunging slab during the Carboniferous.

The late Carboniferous gravitational collapse of the Variscan orogenic crust (Fig. 18E) is accommodated by extension of the upper crust and by lateral flow and exhumation of the partially molten root. This is marked by the formation of crustal-scale domes cored by LP migmatites and heterogeneous granites coeval with the emplacement of syntectonic laccoliths in the footwall of low-angle detachments. These are complementary to a refractory granulitic lower crust formed by protracted high-temperature metamorphism, partial melting and melt/solid segregation.

According to this new model consistent with physical modelling, continuous and protracted presence of melt in the root of the orogenic crust plays a crucial role in the tectonic evolution of the Variscan belt by (i) triggering syn-orogenic exhumation of subducted continental units decoupled from the downgoing slab; (ii) controlling the formation and lateral development of an orogenic plateau; and finally, (iii) guiding the formation of metamorphic core complexes during orogenic gravitational collapse. Crustal melting starts with segregation of melts from the subducted oceanic and continental units in the Devonian. Subsequently during the Carboniferous, the emplacement of plutons and volcanics during the building of the orogenic plateau has a contribution from the partially molten crust and from the mantle. The maintenance of a partially molten crust for several tens of Myrs is probably favored by the combined effects of radioactive heat production and increasing mantle heat flux owing to removal of the lithospheric mantle slab. It ended with the extraction of differentiated magmas and crystallization of the collapsed partially molten orogenic root. The contrasting Carboniferous geological record between the Western and Eastern French Massif Central separated by the Sillon Houiller is consistent 
with a more pronounced slab retreat in the East toward the Paleotethys free boundary. The Eastern part of the French Massif Central is indeed characterized by (i) the abundance of $\mathrm{Mg}-\mathrm{K}$ diorites (vaugnerites) and KCG-type granites indicating the contribution of mantle-derived magmas, and (ii) a widespread extension associated with the development of the Velay and Montagne Noire migmatite domes (Fig. 19).

Acknowledgments. This paper results from a long gestation process. First of all, Olivier Vanderhaeghe is very grateful to Patrick Ledru and Jean-Michel Caron for their initiation to the geology of the Massif Central Français and also to Jean-Pierre Burg for his encouragements in developing the structural analysis of migmatites. The authors address a special thank to Philippe Rossi, director of the French geological mapping program, and the BRGM for financial support at different stages. Arnaud Villaros acknowledges financial support from the Labex VOLTAIRE (ANR-10-LABX-100-01) and JeanFrançois Moyen, Simon Couzinié and Arnaud Villaros were supported by credits from the INSU 2016 Syster program. A first version of this manuscript, submitted to an IJES special volume following the Variscan 2015 conference, has benefited from the stimulating viewpoint of Roberto Weinberg and from the critical opinion of an anonymous reviewer. As a result, the present version was considerably augmented and was itself significantly improved owing to the constructive review of Jacques Malavieille and from the challenging comments of an anonymous reviewer not sharing the same vision of this segment of the Variscan belt. The authors thank Olivier Averbuch and Laurent Jolivet for their careful and balanced editorial handing.

\section{References}

Aerden DGAM. 1998. Tectonic evolution of the Montagne Noire and a possible orogenic model for syncollisional exhumation of deep rocks, Variscan belt, France. Tectonics 17: 62-79. https://doi.org/ 10.1029/97TC02342.

Aerden DG, Malavieille J. 1999. Origin of a large-scale fold nappe in the Montagne Noire Variscan belt, France. J. Struct. Geol. 21: 1321-1333.

Alexandre P. 2007. U-Pb zircon SIMS ages from the French Massif Central and implication for the pre-Variscan tectonic evolution in Western Europe. Comptes Rendus Geosci. 339: 613-621.

Alexandrov P, Cheilletz A, Deloule É, Cuney M. 2000. 319 7 Ma crystallization age for the Blond granite (northwest Limousin, French Massif Central) obtained by $\mathrm{U} / \mathrm{Pb}$ ion-probe dating of zircons. Comptes Rendus Académie Sci.-Ser. IIA-Earth Planet. Sci. 330: 617-622.

Alexandrov P, Floc'h J-P, Cuney M, Cheilletz A., 2001. Datation $\mathrm{U}-\mathrm{Pb}$ à la microsonde ionique des zircons de l'unité supérieure de Gneiss dans le Sud Limousin, Massif Central. Comptes Rendus Académie Sci.-Ser. IIA-Earth Planet. Sci. 332: 625-632.

Altherr R, Kalt A. 1996. Metamorphic evolution of ultrahigh-pressure garnet peridotites from the Variscan Vosges Mts. (France). Chem. Geol. 134: 27-47.

Annen C, Sparks RSJ. 2002. Effects of repetitive emplacement of basaltic intrusions on thermal evolution and melt generation in the crust. Earth Planet. Sci. Lett. 203: 937-955.

Arnaud F, Burg J-P. 1993. Microstructures des mylonites schisteuses : cartographie des chevauchements varisques dans les Cévennes et détermination de leur cinématique. Comptes Rendus Académie Sci.
Sér. 2 Mécanique Phys. Chim. Sci. Univers Sci. Terre 317: 14411447.

Arnaud F, Boullier AM, Burg J-P. 2004. Shear structures and microstructures in micaschists: the Variscan Cévennes duplex (French Massif Central). J. Struct. Geol. 26: 855-868.

Arnold J, Jacoby WR, Schmeling H, Schott B. 2001. Continental collision and the dynamic and thermal evolution of the Variscan orogenic crustal root-Numerical models. J. Geodyn. 31: 273-291. https://doi.org/10.1016/S0264-3707(00)00023-5.

Arthaud F, Matte P. 1975. Les décrochements tardi-hercyniens du sud-ouest de l'Europe. Géométrie et essai de reconstitution des conditions de la déformation. Tectonophysics 25: 139-171.

Arthaud F, Mattauer M, Proust F. 1966. La structure et la microtectonique des nappes hercyniennes de la Montagne Noire. In: Colloque "Étages Tectoniques », À La Baconnière, NeuchâTel, $247 \mathrm{p}$.

Artyushkov EV. 1973. Stresses in the lithosphere caused by crustal thickness inhomogeneities. J. Geophys. Res. 78: 7675-7708. https://doi.org/10.1029/JB078i032p07675.

Audren C, Feybesse JL, Tegyey M, Triboulet C. 1987. Relations entre déformations et cristallisations et chemins «PTtd» des micaschistes polyphasés d'Echassières. Modèle d'évolution géodynamique. Géol Fr. 2: 43-45.

Autran A, Cogné J. 1980. La zone interne de l'orogène varisque dans l'Ouest de la France et sa place dans le développement de la chaîne hercynienne. Mém. BRGM 191-202.

Autran A, Guillot PL. 1978. L'évolution métamorphique du Limousin (Massif Central français) au Paléozoïque. Relation entre les cycles Calédonien et Varisque. In: La Chaîne Varisque d'Europe Moyenne et Occidentale, pp. 211-226.

Averbuch O, Piromallo C. 2012. Is there a remnant Variscan subducted slab in the mantle beneath the Paris basin? Implications for the late Variscan lithospheric delamination process and the Paris basin formation. Tectonophysics 558: 70-83.

Ballèvre M, Balé P. 1992. Forage scientifique de Sancerre-Couy: tectonique et métamorphisme. Géologie Fr. 135-138.

Ballèvre M, Kienast JR, Paquette J-L. 1987. Le métamorphisme éclogitique dans la nappe hercynienne de Champtoceaux (Massif Armoricain). Comptes Rendus Académie Sci. Sér. 2 Mécanique Phys. Chim. Sci. Univers Sci. Terre 305: 127-131.

Ballèvre M, Capdevila R, Guerrot C, Peucat J-J. 2002. Discovery of an alkaline orthogneiss in the eclogite-bearing Cellier Unit (Champtoceaux Complex, Armorican Massif): a new witness of the Ordovician rifting. Comptes Rendus Geosci. 334: 303-311.

Ballèvre M, Bosse V, Ducassou C, Pitra P. 2009. Palaeozoic history of the Armorican Massif: models for the tectonic evolution of the suture zones. Comptes Rendus Geosci. 341: 174-201.

Ballèvre M, Martínez Catalán JR, López-Carmona A, Pitra P, Abati J, Fernández RD, et al. 2014. Correlation of the nappe stack in the Ibero-Armorican arc across the Bay of Biscay: a joint FrenchSpanish project. Geol. Soc. Lond. Spec. Publ. 405: 77-113. https:// doi.org/10.1144/SP405.13.

Barbarin B. 1999. A review of the relationships between granitoid types, their origins and their geodynamic environments. Lithos 46: 605-626.

Barbarin B, Belin JM. 1982. Mise en évidence du cisaillement ductile hercynien «St Gervais-L'Hermitage» (Massif central français). CR Acad Sci Paris II 294: 1377-1380.

Barbey P, Marignac C, Montel JM, Macaudiere J, Gasquet D, Jabbori J. 1999. Cordierite growth textures and the conditions of genesis and emplacement of crustal granitic magmas: the Velay granite complex (Massif Central, France). J. Petrol. 40: 14251441. 
Barbey P, Cheilletz A, Laumonier B. 2001. The Canigou orthogneisses (Eastern Pyrenees, France, Spain): an Early Ordovician rapakivi granite laccolith and its contact aureole. Comptes Rendus Académie Sci.-Ser. II A-Earth Planet. Sci. 332: 129-136.

Barbey P, Villaros A, Marignac C, Montel J-M. 2015. Multiphase melting, magma emplacement and PT-time path in late-collisional context: the Velay example (Massif Central, France). Bull. Soc. Geol. Fr. 186: 93-116.

Barboza SA, Bergantz GW, Brown M. 1999. Regional granulite facies metamorphism in the Ivrea zone: Is the Mafic Complex the smoking gun or a red herring? Geology 27: 447-450.

Bard JP, Burg JP, Matte P, Ribeiro A. 1980. La chaine hercynienne d'Europe occidentale en termes de tectonique des plaques. Géologie Eur. 108: 233-46.

Batias P, Duthou JL. 1979. Age Viséen supérieur du granite porphyrö̈de de Vienne-Tournon (Massif Central français). In: Proc. $7^{e}$ La Réun. Annu. Sci. Terre Lyon.

Bé Mézémé E. 2005. Contribution de la géochronologie U-Th-Pb sur monazite à la compréhension de la fusion crustale dans la chaîne Varisque française et implication géodynamique. Orléans.

Bé Mézémé E, Cocherie A, Faure M, Legendre O, Rossi P. 2006. Electron microprobe monazite geochronology of magmatic events: examples from Variscan migmatites and granitoids, Massif Central, France. Lithos 87: 276-288.

Bea F, Montero P. 1999. Behavior of accessory phases and redistribution of $\mathrm{Zr}$, REE, Y, Th, and $\mathrm{U}$ during metamorphism and partial melting of metapelites in the lower crust: an example from the Kinzigite Formation of Ivrea-Verbano, NW Italy. Geochim. Cosmochim. Acta 63: 1133-1153.

Bébien J. 1971. Eléments nouveaux sur le volcanisme dévonodinantien de l'extrémité sud-ouest du faisceau synclinal du Morvan. Cr Seances Acad Sci Paris 273: 466-8.

Becq-Giraudon J-F. 1993. Problèmes de la biostratigraphie dans le Paléozoïque supérieur continental (Stéphanien-Autunien) du Massif Central. Geodin. Acta 6: 219-224.

Becq-Giraudon J-F, Montenat C, Van Den Driessche J. 1996. Hercynian high-altitude phenomena in the French Massif Central: tectonic implications. Palaeogeogr. Palaeoclimatol. Palaeoecol. 122: 227-241.

Bellot J-P. 2001. La structure de la croûte varisque du Sud-Limousin (Massif central français) et ses relations avec les minéralisations aurifères tardi-orogéniques: Apport des données géologiques, gitologiques, géophysiques et de la modélisation 3D. Université de Montpellier II.

Bellot J-P. 2007. Extensional deformation assisted by mineralised fluids within the brittle-ductile transition: Insights from the southwestern Massif Central, France. J. Struct. Geol. 29: 225-240.

Bellot J-P, Roig J-Y. 2007. Episodic exhumation of HP rocks inferred from structural data and PT paths from the southwestern Massif Central (Variscan belt, France). J. Struct. Geol. 29: 1538-1557.

Berger J, Femenias O, Mercier JCC, Demaiffe D. 2006. A Variscan slow-spreading ridge (MOR-LHOT) in Limousin (French Massif Central): magmatic evolution and tectonic setting inferred from mineral chemistry. Mineral. Mag. 70, 175-185.

Berger J, Féménias O, Ohnenstetter D, Bruguier O, Plissart G, Mercier J-CC, et al. 2010a. New occurrence of UHP eclogites in Limousin (French Massif Central): age, tectonic setting and fluidrock interactions. Lithos 118: 365-382.

Berger J, Femenias O, Ohnenstetter D, Plissart G, Mercier J-C. 2010 b. Origin and tectonic significance of corundum-kyanite-sapphirine amphibolites from the Variscan French Massif Central. J. Metamorph. Geol. 28: 341-360.
Bernard-Griffiths J. 1975. Essai sur la signification des âges au strontium dans une série métamorphique: le Bas Limousin, MassifCentral français. Université de Clermont, Unité d'enseignement et de recherche de sciences.

Bernard-Griffiths J, Cornichet J. 1985. Origin of eclogites from South Brittany, France: a Sm/Nd isotopic and REE study. Chem. Geol. Isot. Geosci. Sect. 52: 185-201.

Bernard-Griffiths J, Cantagrel J-M, Duthou J-L. 1977. Radiometric evidence for an Acadian tectonometamorphic event in western Massif Central Francais. Contrib. Mineral. Petrol. 61: 199-212.

Bernard-Griffiths J, Gebauer D, Grunenfelder M, Piboule M. 1985. The tonalite belt of Limousin (French Central Massif); U-Pb zircon ages and geotectonic implications. Bull. Société Géologique Fr. 1: 523-529.

Bertaux J, Becq-Giraudon J-F, Jacquemin H. 1993. Les bassins anthracifères de la région de Roanne (Loire, Massif central) marqueurs d'une tectonique active durant le Viséen. Géologie Fr. 4: $3-10$.

Berthier F, Duthou JL, Roques M. 1979. Datation géochronologique $\mathrm{Rb} / \mathrm{Sr}$ sur roches totales du granite de Guéret (Massif Central). Age fini-Dévonien de mise en place de l'un de ses facies types. Bull BRGM 1: 59-72.

Bertrand M. 1887. La chaine des Alpes et la formation du continent européen. Bull. Soc. Geol. Fr. 3: 440-442.

Bertrand JM, Leterrier J, Cuney M, Brouand M, Stussi JM, Delaperrière E, et al. 2001. Géochronologie U-Pb sur zircons de granitoïdes du Confolentais, du massif de Charroux-Civray (seuil du Poitou) et de Vendée. Géologie Fr. 1: 167-189.

Bird P. 1991. Lateral extrusion of lower crust from under high topography in the isostatic limit. J. Geophys. Res. 96: 10275. https://doi.org/10.1029/91JB00370.

Bitri A, Truffert C, Bellot J-P, Bouchot V, Ledru P, Milési J-P, et al. 1999. Imagery of crustal-scale As-Au-Sb hydrothermal palaeofields in the Variscan belt: vertical seismic reflection (GeoFrance 3D: French Massif Central). Comptes Rendus Acad. Sci. Ser. II-A Earth Planet. Sci. 329: 771-777.

Bitri A, Brun J-P, Gapais D, Cagnard F, Gumiaux C, Chantraine J, et al. 2010. Deep reflection seismic imaging of the internal zone of the South Armorican Hercynian belt (western France) (ARMOR 2/Géofrance 3D Program). Comptes Rendus Geosci. 342: 448-452.

Bodinier J-L, Burg J-P. 1981. Evolution métamorphique et tectonique des séries cristallophylliennes du Rouergue occidental: mise en évidence d'un chevauchement dans la région de Najac (Aveyron). Bull BRGM I: 315-339.

Bodinier J-L, Giraud A, Dupuy C, Leyreloup A, Dostal J. 1986. Caracterisation geochimique des metabasites associees a la suture meridionale hercynienne; Massif Central francais et Chamrousse (Alpes). Bull. Société Géologique Fr. 2: 115-123.

Boehnke P, Watson EB, Trail D, Harrison TM, Schmitt AK. 2013. Zircon saturation re-revisited. Chem. Geol. 351: 324-334. https:// doi.org/10.1016/j.chemgeo.2013.05.028.

Bonijoly D, Castaing CH. 1984. Fracturation et genèse des bassins stéphaniens du Massif central français en régime compressif. Ann Soc Geol Nord 103: 187-199.

Bosse V, Feraud G, Ruffet G, Ballèvre M, Peucat J-J, De Jong K. 2000. Late Devonian subduction and early-orogenic exhumation of eclogite-facies rocks from the Champtoceaux Complex (Variscan belt, France). Geol. J. 35: 297-325.

Bosse V, Féraud G, Ballevre M, Peucat J-J, Corsini M. 2005. Rb-Sr and $40 \mathrm{Ar} / 39 \mathrm{Ar}$ ages in blueschists from the Ile de Groix (Armorican Massif, France): implications for closure mechanisms in isotopic systems. Chem. Geol. 220: 21-45. 
Bouchardon J-L, Santallier D, Briand B, Ménot R-P, Piboule M. 1989. Eclogites in the French Palaeozoic Orogen: geodynamic significance. Tectonophysics 169: 317-332.

Bouilhol P, Leyreloup AF, Delor C, Vauchez A, Monié P. 2006. Relationships between lower and upper crust tectonic during doming: the mylonitic southern edge of the Velay metamorphic core complex (Cévennes-French Massif Central). Geodin. Acta 19: 137-153.

Boutin R, Montigny R. 1993. Datation 40Ar-39Ar des amphibolites $\mathrm{du}$ complexes leptynoamphibolique du Plateau d'Aigurande: collision varisque à $390 \mathrm{Ma}$ dans le Nord-Ouest du Massif Central français. Comptes Rendus Académie Sci. Sér. 2 Mécanique Phys. Chim. Sci. Univers Sci. Terre 316: 1391-1398.

Briand B. 1978. Métamorphisme inverse et chevauchement de type himalayen dans la série de la vallée du Lot. CR Acad Sci Paris 286: 729-731.

Briand B, Gay M. 1978. La série inverse de Saint-Geniez-d'Olt: évolution métamorphique et structurale. Bull. BRGM 3: 167-186.

Briand B, Piboule M. 1979. Les métabasites de la série de Marvejols (Massif central) : témoins d'un magmatisme tholéitique d'arrièrearc cambro-ordovicien? Bull BRGM 2(I): 131-171.

Briand B, Piboule M, Bouchardon JL. 1988. Diversite geochimique des metabasites des groupes leptyno-amphiboliques du Rouergue et de Marvejols (Massif Central); origine et implications. Bull. Société Géologique Fr. 4: 489-498.

Briand B, Bouchardon J-L, Ouali H, Piboule M, Capiez P. 1995. Geochemistry of bimodal amphibolitic-Felsic gneiss complexes from eastern Massif Central, France. Geol. Mag. 132: 321-337.

Briand B, Duthou J-L, Guerrot C, Chenevoy M. 2002. Les « granites à tablettes d'orthose » du Vivarais, témoins d'un magmatisme postépaississement d'âge Dinantien inférieur; identification d'une unité géologique Nord-Ouest-Vivarais. Comptes Rendus Geosci. 334: 741-747.

Brichau S, Respaut J-P, Monié P. 2008. New age constraints on emplacement of the Cévenol granitoids, South French Massif Central. Int. J. Earth Sci. 97: 725-738.

Brown M. 2001. Orogeny, migmatites and leucogranites: a review. J. Earth Syst. Sci. 110: 313-336.

Brown M, Rushmer T. 1997. The role of deformation in the movement of granitic melt: views from the laboratory and the field. Deform. -Enhanc. Fluid Transp. Earth's Crust Mantle 8: 111-144.

Brown M, Solar GS. 1998. Granite ascent and emplacement during contractional deformation in convergent orogens. J. Struct. Geol. 20: $1365-1393$.

Brueckne HK, Medaris LG. 2000. A general model for the intrusion and evolution of "mantle" garnet peridotites in high-pressure and ultra-high-pressure metamorphic terranes. J. Metamorph. Geol. 18: 123-133.

Bruguier O, Becq-Giraudon JF, Bosch D, Lancelot JR. 1998. Late Visean hidden basins in the internal zones of the Variscan belt: $\mathrm{U}-\mathrm{Pb}$ zircon evidence from the French Massif Central. Geology 26: 627-630.

Bruguier O, Becq-Giraudon JF, Champenois M, Deloule E, Ludden J, Mangin D. 2003. Application of in situ zircon geochronology and accessory phase chemistry to constraining basin development during post-collisional extension: a case study from the French Massif Central. Chem. Geol. 201: 319-336.

Buck WR. 1991. Modes of continental lithospheric extension. J. Geophys. Res. Solid Earth 96: 20161-20178. https://doi.org/ 10.1029/91JB01485.

Burg J-P, Leyreloup A. 1989. Métamorphisme granulitique de roches granitiques en Rouergue (Massif Central). Comptes Rendus
Académie Sci. Sér. 2 Mécanique Phys. Chim. Sci. Univers Sci. Terre 309: 719-725.

Burg JP, Matte PJ. 1978. A cross section through the French Massif Central and the scope of its Variscan geodynamic evolution. Z. Dtsch. Geol. Ges. 429-460.

Burg J-P, Vanderhaeghe O. 1993. Structures and way-up criteria in migmatites, with application to the Velay dome (French Massif Central). J. Struct. Geol. 15: 1293-1301.

Burg JP, Matte P, Leyreloup A, Marchand J. 1984. Inverted metamorphic zonation and large-scale thrusting in the Variscan Belt: an example in the French Massif Central. Geol. Soc. Lond. Spec. Publ. 14: 47-61.

Burg J-P, Delor C, Leyreloup A. 1986. Le massif du Lévézou et les séries adjacentes du Rouergue oriental. Nouvelles données pétrographiques et structurales. Géologie Fr. 3: 229-272.

Burg J-P, Bale P, Brun J-P, Girardeau J. 1987. Stretching lineation and transport direction in the Ibero-Armorican arc during the silurodevonian collision. Geodin. Acta 1: 71-87. https://doi.org/10.1080/ 09853111.1987.11105126.

Burg J-P, Castaing C, Chantraine J, Hottin A-M, Kienast J-R, Mégnien C, et al. 1989a. Les formations métamorphiques traversées par le sondage de Sancere-Couy (programme GPF). Nouveau jalon de la chaîne varisqe. Comptes Rendus Acad. Sci. 2: 1819-1824.

Burg JP, Leyreloup AF, Romney F, Delor CP. 1989b. Inverted metamorphic zonation and Variscan thrust tectonics in the Rouergue area (Massif Central, France): PTt record from mineral to regional scale. Geol. Soc. Lond. Spec. Publ. 43: 423-439.

Burg J-P, Brun J-P, Van Den Driessche J. 1990. Le sillon houiller du Massif Central français: faille de transfert pendant l'amincissement crustal de la chaîne. Comptes Rendus Académie Sci. Sér. 2 Mécanique Phys. Chim. Sci. Univers Sci. Terre 311: 147-152.

Burg J-P, Van den Driessche J, Brun J-P. 1993. Syn-to post-thickening extension in the Variscan Belt of Western Europe: modes and structural consequences. Géologie Fr. 3: 33-51.

Bussien D, Bussy F, Masson H, Magna T, Rodionov N. 2008. Variscan lamprophyres in the Lower Penninic domain (Central Alps): age and tectonic significance. Bull. Société Géologique Fr. 179: $369-381$.

Cabanis B, Guillot PL, Santallier D, Jaffrezic H, Meyer G, Treuil M. 1983. Apport des elements-traces a l'etude geochimique des metabasites du Bas Limousin. Bull. Société Géologique Fr. 7: 563 574.

Caen-Vachette M. 1979. Age Cambrien des rhyolites transformées en leptynites dans la série métamorphique du Pilat (Massif Central français). C R Hebd Séanc Acad Sci Paris 289: 997-1000.

Caen-Vachette M, Couturié JP, Didier J. 1981. Age westphalien du granite de Rocles (Cévennes, massif Central Français). Comptes Rendus L'Académie Sci. 293: 957-960.

Caen-Vachette M, Gay M, Peterlongo J-M, Pitiot P, Vitel G. 1984. Age radiométrique du granite syntectonique du gouffre d'Enfer et du métamorphisme hercynien dans la série de basse pression du Pilat (Massif Central Français). Comptes-Rendus Séances Académie Sci. Sér. 2 Mécanique-Phys. Chim. Sci. Univers Sci. Terre 299: 1201-1204.

Cagnard F, Durrieu N, Gapais D, Brun J-P, Ehlers C. 2006. Crustal thickening and lateral flow during compression of hot lithospheres, with particular reference to Precambrian times. Terra Nova 18: 7278. https://doi.org/10.1111/j.1365-3121.2005.00665.x.

Campbell IH, Stepanov AS, Liang H-Y, Allen CM, Norman MD, Zhang Y-Q, et al. 2014. The origin of shoshonites: new insights from the Tertiary high-potassium intrusions of eastern Tibet. 
Contrib. Mineral. Petrol. 167. https://doi.org/10.1007/s00410-0140983-9.

Carlier De Veslud CL, Alexandre P, Cuney M, Ruffet G, Cheilletz A, Virlogeux D. 2004. Thermochronologie 40Ar/39Ar et evolution thermique des granitoides meso-varisques du complexe plutonique de Charroux-Civray (Seuil de Poitou)(4 fig.). Bull. Soc. Geol. Fr. 175: $147-156$.

Caron C. 1994. Les minéralisations $\mathrm{Ph}-\mathrm{Zn}$ associées au paléozoique inférieur d'Europe méridionale. Traçage isotopique $\mathrm{Pb}-\mathrm{Pb}$ des gites de l'iglesiente(SW Sardaigne) et des Cévennes et évolution du socle encaissant par la géochronologie U-Pb, 40Ar-39Ar et K-Ar.

Carrat HG, Zimmermann J-L. 1984. Ages K-Ar des roches volcaniques du Morvan. Comptes-Rendus Séances Académie Sci. Sér. 2 Mécanique-Phys. Chim. Sci. Univers Sci. Terre 299: 801-803.

Cartannaz C. 2006. Magmatismes et déformations polyphasés: exemple des massifs de Guéret et de millevaches (massif central français): origine des magmas et contexte de mise en place. Besançon.

Cartannaz C, Rolin P, Cocherie A, Henry P, Rossy M. 2007a. Feuille Aubusson, $667 \mathrm{p}$.

Cartannaz C, Rolin P, Cocherie A, Marquer D, Legendre O, Fanning CM, et al. 2007b. Characterization of wrench tectonics from dating of syn-to post-magmatism in the north-western French Massif Central. Int. J. Earth Sci. 96: 271-287.

Cartier C, Faure M, Lardeux H. 2001. The Hercynian orogeny in the South Armorican Massif (Saint-Georges-sur-Loire Unit, Ligerian Domain, France): rifting and welding of continental stripes. Terra Nova 13: 143-149.

Castiñeiras P, Navidad M, Liesa M, Carreras J, Casas JM. 2008. U-Pb zircon ages (SHRIMP) for Cadomian and Early Ordovician magmatism in the Eastern Pyrenees: new insights into the preVariscan evolution of the northern Gondwana margin. Tectonophysics 461: 228-239.

Chantraine J, Autran A, Cavelier C, et al. 1996. Carte géologique de la France.

Chantraine J, Autran A, Cavelier C, Clozier L. 2003. Carte géologique de la France à l'échelle du millionième. Bureau de recherches géologiques et minières.

Chardon D, Gapais D, Cagnard F. 2009. Flow of ultra-hot orogens: a view from the Precambrian, clues for the Phanerozoic. Tectonophysics 477: 105-118.

Charles N, Faure M, Chen Y. 2009. The Montagne Noire migmatitic dome emplacement (French Massif Central): new insights from petrofabric and AMS studies. J. Struct. Geol. 31: 1423-1440.

Chauvet A, Volland-Tuduri N, Lerouge C, Bouchot V, Monié P, Charonnat X, et al. 2012. Geochronological and geochemical characterization of magmatic-hydrothermal events within the Southern Variscan external domain (Cévennes area, France). Int. J. Earth Sci. 101: 69-86. https://doi.org/10.1007/s00531-0110639-1.

Chelle-Michou C, Laurent O, Moyen J-F, Block S, Paquette J-L, Couzinié S, et al. 2017. Pre-Cadomian to late-Variscan odyssey of the eastern Massif Central, France: formation of the West European crust in a nutshell. Gondwana Res. 46: 170-190.

Chemenda AI, Mattauer M, Bokun AN. 1996. Continental subduction and a mechanism for exhumation of high-pressure metamorphic rocks: new modelling and field data from Oman. Earth Planet. Sci. Lett. 143: 173-182.https://doi.org/10.1016/0012-821X(96)00123-9.

Chenevoy M, Ravier J. 1971. Caractères généraux des métamorphismes du Massif Central. In: Symposium J. Jung, ClermontFerrand, pp. 109-132.
Choukroune P, Gapais D, Matte P. 1983. Tectonique hercynienne et deformation cisaillante: La faille ductile senestre de la Marche (Massif Central Français). CR Acad Sci 296: 859-862.

Choulet F, Faure M, Fabbri O, Monié P. 2012. Relationships between magmatism and extension along the Autun-La Serre fault system in the Variscan Belt of the eastern French Massif Central. Int. J. Earth Sci. 101: 393-413.

Clark AH, Scott DJ, Sandeman HA, Bromley AV, Farrar E. 1998. Siegenian generation of the Lizard ophiolite: $\mathrm{U}-\mathrm{Pb}$ zircon age data for plagiogranite, Porthkerris, Cornwall. J. Geol. Soc. 155: 595598.

Cochelin B, Chardon D, Denèle Y, Gumiaux C, Le Bayon B. 2017. Vertical strain partitioning in hot Variscan crust: Syn-convergence escape of the Pyrenees in the Iberian-Armorican syntax. Bull. Société Géologique Fr. 188: 39.

Cocherie A. 2007. Datations U-Pb (laser-ICPMS-MC) sur zircons et $\mathrm{U}-\mathrm{Th}-\mathrm{Pb}$ sur monazites de granitoïdes du Massif central (carte de Firminy). Rapport BRGM.

Cocherie A, Baudin T, Autran A, Guerrot C, Fanning CM, Laumonier B. 2005. U-Pb zircon (ID-TIMS and SHRIMP) evidence for the early ordovician intrusion of metagranites in the late Proterozoic Canaveilles Group of the Pyrenees and the Montagne Noire (France). Bull. Société Géologique Fr. 176: 269-282.

Cocks LRM, Torsvik TH. 2002. Earth geography from 500 to 400 million years ago: a faunal and palaeomagnetic review. J. Geol. Soc. 159: 631-644.

Cocks LRM, Torsvik TH. 2006. European geography in a global context from the Vendian to the end of the Palaeozoic. Geol. Soc. Lond. Mem. 32: 83-95. https://doi.org/10.1144/GSL. MEM2006.032.01.05.

Collins WJ. 2002. Hot orogens, tectonic switching, and creation of continental crust. Geology 30: 535. https://doi.org/10.1130/00917613(2002)030<0535:HOTSAC $>2.0$.CO;2.

Cook KL, Royden LH. 2008. The role of crustal strength variations in shaping orogenic plateaus, with application to Tibet: Crustal strength and plateau deformation. J. Geophys. Res. Solid Earth 113. https://doi.org/10.1029/2007JB005457.

Copard Y, Disnar J-R, Becq-Giraudon J-F, Boussafir M. 2000. Evidence and effects of fluid circulation on organic matter in intramontane coalfields (Massif Central, France). Int. J. Coal Geol. 44: 49-68.

Costa S. 1989. Age radiométrique ${ }^{39} \mathrm{Ar}-{ }^{40} \mathrm{Ar}$ du métamorphisme des series du Lot et du charriage du groupe leptyno-amphibolique de Marvejols (MCF). Comptes Rendus Académie Sci. Sér. 2 Mécanique Phys. Chim. Sci. Univers Sci. Terre 309: 561-567.

Costa S. 1990. De la collision continentale à l'extension tardiorogénique, 100 millions d'années d'histoire varisque dans le Massif central français-. Une étude chronologique par la méthode ${ }^{40} \mathrm{Ar}-{ }^{39} \mathrm{Ar}$. Université Montpellier 2 Sciences et Techniques du Languedoc.

Costa S. 1992. East-west diachronism of the collisional stageInthe french Massif Central Implications for the European Variscan Orogen. Geodin. Acta 5: 51-68.

Costa S, Maluski H. 1988. Datations par la méthode 39Ar-40Ar de matériel magmatique et métamorphique paléozoïque provenant du forage de Couy-Sancerre (Cher, France). Programme GPF. Comptes Rendus Académie Sci. Sér. 2 Mécanique Phys. Chim. Sci. Univers Sci. Terre 306: 351-356.

Costa S, Rey P, 1995. Lower crustal rejuvenation and growth during post-thickening collapse: Insights from a crustal cross section through a Variscan metamorphic core complex. Geology 23: 905-908. 
Costa S, Maluski H, Lardeaux J-M. 1993. ${ }^{40} \mathrm{Ar} /{ }^{39} \mathrm{Ar}$ chronology of Variscan tectono-metamorphic events in an exhumed crustal nappe: the Monts du Lyonnais complex (Massif Central, France). Chem. Geol. 105: 339-359.

Couturié JP, Caen-Vachette M. 1980. Age Westphalien des leucogranites recoupant le granite de la Margeride (Massif Central français). CR Acad Sci Paris 291: 43-45.

Couturié JP, Vachette-Caen M, Vialette Y. 1979. Age Namurien d'un laccolite granitique différencié par gravité: le granite de la Margeride (Massif Central français). CR Acad Sci Paris 289: 449452.

Couzinié S. 2017. Evolution of the continental crust and significance of the zircon record, a case study from the French Massif Central. Universiteit van Stellenbosch.

Couzinié S, Moyen J-F, Villaros A, Paquette J-L, Scarrow JH, Marignac C. 2014. Temporal relationships between Mg-K mafic magmatism and catastrophic melting of the Variscan crust in the southern part of Velay Complex (Massif Central, France). J. Geosci. 69-86. https://doi.org/10.3190/jgeosci.155.

Couzinié S, Laurent O, Moyen J-F, Zeh A, Bouilhol P, Villaros A. 2016. Post-collisional magmatism: Crustal growth not identified by zircon Hf-O isotopes. Earth Planet. Sci. Lett. 456: 182-195. https:// doi.org/10.1016/j.eps1.2016.09.033.

Couzinié S, Laurent O, Poujol M, Mintrone M, Chelle-Michou C, Moyen J-F, et al. 2017. Cadomian S-type granites as basement rocks of the Variscan belt (Massif Central, France): Implications for the crustal evolution of the north Gondwana margin. Lithos 286: $16-34$.

Couzinié S, Laurent O, Chelle-Michou C, Bouilhol P, Paquette J-L, Gannoun A-M, et al. 2019. Detrital zircon U-Pb-Hf systematics of Ediacaran metasediments from the French Massif Central: Consequences for the crustal evolution of the north Gondwana margin. Precambrian Res. 324: 269-284. https://doi.org/10.1016/j. precamres.2019.01.016.

Cruden AR, Koyi H, Schmeling H. 1995. Diapiric basal entrainment of mafic into felsic magma. Earth Planet. Sci. Lett. 131: 321-340. https://doi.org/10.1016/0012-821X(95)00033-9.

Cuney M, Friedrich M, Blumenfeld P, Bourguignon A, Boiron MC, Vigneresse JL, et al. 1990. Metallogenesis in the French part of the Variscan orogen. Part I: U preconcentrations in pre-Variscan and Variscan formations - a comparison with Sn, W and Au. Tectonophysics 177: 39-57.

Cuney M, Stussi J-M, Brouand M, Dautel D, Michard A, Gros Y, et al. 1993. Géochimie et géochronologie $\mathrm{U} / \mathrm{Pb}$ des diorites quartziques $\mathrm{du}$ Tallud et de Moncoutant: nouveaux arguments pour une extension de la Ligne Tonalitique Limousine en Vendée. Comptes Rendus Académie Sci. Sér. 2 Mécanique Phys. Chim. Sci. Univers Sci. Terre 316: 1383-1390.

Cuney M, Alexandrov P, de Veslud CLC, Cheilletz A, Raimbault L, Ruffet $\mathrm{G}$, et al. 2002. The timing of W-Sn-rare metals mineral deposit formation in the Western Variscan chain in their orogenic setting: the case of the Limousin area (Massif Central, France). Geol. Soc. Lond. Spec. Publ. 204: 213-228.

de Saint Blanquat M. 1993. La faille normale ductile du massif du Saint Barthélémy. Evolution hercynienne des massifs nordpyrénéens catazonaux considérée du point de vue de leur histoire thermique. Geodin. Acta 6: 59-77. https://doi.org/10.1080/ 09853111.1993.11105239.

Delfour J, Guerrot C. 1997. Âge Viséen inférieur du microgranite de Picampoix (Nièvre). Contribution à l'étude du magmatisme carbonifère du Morvan. Géologie Fr. 2: 3-12.

Delfour J, Beurrier M, Tegyey M, Lemiere B, Kerrien Y, Mouterde R, et al. 1989. Carte géologique de la France (1/50 000), feuille de Tarare (697). Orléans : BRGM.
Delor C, Leyreloup A, Bodinier J-L, Burg J-P. 1986. Découverte d'éclogites à glaucophane dans la klippe de Najac (Massif Central, France): nouveaux témoins océaniques d'un stade haute pression dans la chaîne de collision varisque. Comptes Rendus Académie Sci. Sér. 2 Mécanique Phys. Chim. Sci. Univers Sci. Terre 302: 739-744.

Delor C, Burg J-P, Guiraud M, Leyreloup A. 1987. Les métapélites à phengite-chloritoïde-grenat-staurotide-disthène de la klippe de Najac-Carmaux: nouveaux marqueurs d'un métamorphisme de haute pression varisque en Rouergue occidental. Comptes Rendus Académie Sci. Sér. 2 Mécanique Phys. Chim. Sci. Univers Sci. Terre 305: 589-595.

Deloule E, Alexandrov P, Cheilletz A, Laumonier B, Barbey P. 2002. In-situ U-Pb zircon ages for Early Ordovician magmatism in the eastern Pyrenees, France: the Canigou orthogneisses. Int. J. Earth Sci. 91: 398-405.

Demange M. 1980. Arguments for allochemistry of the cordierite migmatites in the agout massif (Montagne-Noire, France). Comptes Rendus Hebd. Séances Académie Sci. Sér. D 291: $367-$ 370.

Demange M, Jamet P. 1985. Le stade majeur du métamorphisme est de type moyenne pression sur le flanc sud de la Montagne Noire dans la région de Labastide-Rouairoux (Tarn, France). Comptes Rendus Académie Sci. Sér. 2 Mécanique Phys. Chim. Sci. Univers Sci. Terre 301: 603-606.

Demay A. 1948. Tectonique antéstéphanienne du Massif central. Impr. nationale.

Denèle Y, Laumonier B, Paquette J-L, Olivier P, Gleizes G, Barbey P. 2014. Timing of granite emplacement, crustal flow and gneiss dome formation in the Variscan segment of the Pyrenees. Geol. Soc. Lond. Spec. Publ. 405: 265-287.

Dewey JF, Burke KC. 1973. Tibetan, Variscan, and Precambrian basement reactivation: products of continental collision. J. Geol. 81: 683-692.

Didier A, Bosse V, Boulvais P, Bouloton J, Paquette J-L, Montel J-M, et al. 2013. Disturbance versus preservation of $\mathrm{U}-\mathrm{Th}-\mathrm{Pb}$ ages in monazite during fluid-rock interaction: textural, chemical and isotopic in situ study in microgranites (Velay Dome, France). Contrib. Mineral. Petrol. 165: 1051-1072.

D'Lemos RS, Strachan RA, Topley CG. 1990. The Cadomian orogeny in the North Armorican Massif: a brief review. Geol. Soc. Lond. Spec. Publ. 51: 3-12. https://doi.org/10.1144/GSL. SP1990.051.01.01.

Do Couto D, Faure M, Augier R, Cocherie A, Rossi P, Li X-H, et al. 2016. Monazite U-Th-Pb EPMA and zircon U-Pb SIMS chronological constraints on the tectonic, metamorphic, and thermal events in the inner part of the Variscan orogen, example from the Sioule series, French Massif Central. Int. J. Earth Sci. 105: 557-579.

Domeier M. 2016. A plate tectonic scenario for the Iapetus and Rheic oceans. Gondwana Res. 36: 275-295. https://doi.org/10.1016/j. gr.2015.08.003.

Domeier M, Torsvik TH. 2014. Plate tectonics in the late Paleozoic. Geosci. Front. 5: 303-350. https://doi.org/10.1016/j. gsf.2014.01.002.

Doublier MP, Potel S, Wemmer K. 2006. Age and grade of metamorphism in the eastern Monts de Lacaune-implications for the collisional accretion in Variscan externides (French Massif Central). Geodin. Acta 19: 391-407.

Doublier MP, Potel S, Wemmer K. 2015. The tectono-metamorphic evolution of the very low-grade hangingwall constrains two-stage gneiss dome formation in the Montagne Noire (Southern France). J. Metamorph. Geol. 33: 71-89. https://doi.org/10.1111/jmg.12111.

Downes H, Duthou J-L. 1988. Isotopic and trace-element arguments for the lower-crustal origin of Hercynian granitoids and 
pre-Hercynian orthogneisses, Massif Central (France). Chem. Geol. 68: 291-308.

Downes H, Leyreloup A. 1986. Granulitic xenoliths from the French Massif Central-Petrology, $\mathrm{Sr}$ and $\mathrm{Nd}$ isotope systematics and model age estimates. Geol. Soc. Lond. Spec. Publ. 24: 319-330.

Downes H, Dupuy C, Leyreloup AF. 1990. Crustal evolution of the Hercynian belt of Western Europe: Evidence from lower-crustal granulitic xenoliths (French Massif Central). Chem. Geol. 83: 209231.

Downes H, Kempton PD, Briot D, Harmon RS, Leyreloup AF. 1991. $\mathrm{Pb}$ and $\mathrm{O}$ isotope systematics in granulite facies xenoliths, French Massif Central: implications for crustal processes. Earth Planet. Sci. Lett. 102: 342-357.

Downes H, Shaw A, Williamson BJ, Thirlwall MF. 1997. Sr, Nd and $\mathrm{Pb}$ isotopic evidence for the lower crustal origin of Hercynian granodiorites and monzogranites, Massif Central, France. Chem. Geol. 140: 289-289.

Dubuisson G, Mercier J-C, Girardeau J, Frison J-Y. 1989. Evidence for a lost ocean in Variscan terranes of the western Massif Central, France. Nature 337: 729.

Ducrot J, Lancelot JR, Reille JL. 1979. Datation en Montagne Noire d'un temoin d'une phase majeure d'amincissement crustal caracteristique de 1'Europe prevarisque. Bull. Société Géologique Fr. 7: 501-505.

Ducrot J, Lancelot JR, Marchand J. 1983. Datation U-Pb sur zircons de l'eclogite de la Borie (Haut-Allier, France) et consequences sur l'evolution ante-hercynienne de l'Europe occidentale. Earth Planet. Sci. Lett. 62: 385-394.

Dufour E. 1985. Granulite facies metamorphism and retrogressive evolution of the Monts du Lyonnais metabasites (Massif Central, France). Lithos 18: 97-113.

Duguet M. 2003. Evolution tectono-métamorphique des unités de type Thiviers-Payzac dans la chaîne hercynienne française (Massif Central et Vendée). Université d'Orléans.

Dupis A, Robin G, Durandeau A, Lameyre J, Vauchelle L. 1990. Etude geophysique de l'extremite occidentale du granite de Gueret. Bull. Société Géologique Fr. 6: 683-691.

Dupraz J, Didier J. 1988. Le complexe anatectique du Velay (Massif central français): structure d'ensemble et évolution géologique. Géologie Fr. 4: 73-88.

Dupuy C, Leyreloup A, Vernieres J. 1979. The lower continental crust of the Massif Central (Bournac, France)-With special references to REE, U and Th composition, evolution, heat-flow production. Phys. Chem. Earth 11: 401-415.

Dusséaux C. 2019. Topographic reconstructions of the Variscan belt of Western Europe through the study of fossil hydrothermal systems. University of Pymouth.

Dusséaux C, Gébelin A, Boulvais P, Gardien V, Grimes S, Mulch A. 2019. Meteoric fluid-rock interaction in Variscan shear zones. Terra Nova. https://doi.org/10.1111/ter.12392.

Duthou JL. 1978. Les granitoides du Haut Limousin (Massif central francais). Chronologie $\mathrm{Rb}-\mathrm{Sr}$ de leur mise en place. Le thermometamorphisme carbonifere. Bull. Société Géologique Fr. 7: 229-235.

Duthou JL, Piboule M, Gay M, Dufour E. 1981. Rb-Sr Dating of orthogranulites from the Monts du Lyonnais (Massif Central, France). Comptes Rendus Académie Sci. Sér. II 292: 749-752.

Duthou JL, Cantagrel J, Didier J, Vialette Y. 1984. Palaeozoic granitoids from the French Massif Central: age and origin studied by $87 \mathrm{Rb} / 87 \mathrm{Sr}$ system. Phys. Earth Planet. Inter. 35: 131-144.

Duthou JL, Chenevoy M, Gay M. 1994. Rb-Sr middle Devonian age of cordierite bearing migmatites from Lyonnais area (French
Massif Central). Comptes Rendus Acad. Sci. Ser. 2 Sci. Terre Planetes 319: 791-796.

Duthou J-L, Chenevoy M, Gay M. 1998. Présence d'un magmatisme d'âge Viséen moyen dans le versant sud du massif du Pilat, Massif central oriental ; conséquences. Comptes Rendus Académie Sci.Ser. IIA-Earth Planet. Sci. 327: 749-754.

Echtler H. 1990. Geometry and kinematics of recumbent folding and low-angle detachment in the Pardailhan nappe (Montagne Noire, Southern French Massif Central). Tectonophysics 177: 109-123.

Echtler H, Malavieille J. 1990. Extensional tectonics, basement uplift and Stephano-Permian collapse basin in a late Variscan metamorphic core complex (Montagne Noire, Southern Massif Central). Tectonophysics 177: 125-138.

Edel JB, Schulmann K, Lexa O, Lardeaux JM. 2018. Late Palaeozoic palaeomagnetic and tectonic constraints for amalgamation of Pangea supercontinent in the European Variscan belt. Earth Sci. Rev. 177: 589-612.

Ellenberger F. 1967. Replis de micaschistes et tectonique d'infrastructure au sein du massif gneissique du Caroux (zone axiale de la Montagne Noire). Impr. Louis-Jean.

Engel W. 1984. Migration of folding and flysch sedimentation on the southern flank of the variscan belt (Montagne Noire, Mouthoumet massif, Pyrenees). Z. Dtsch. Geol. Ges. 279-292.

Engel W, Feist R, Franke W. 1978. Synorogenic gravitational transport in the Carboniferous of the Montagne Noire (S-France). Z. Dtsch. Geol. Ges. 461-472.

Engel W, Feist R, Franke W. 1981. Le Carbonifère anté-stéphanien de la Montagne Noire: rapports entre mise en place des nappes et sédimentation. Bureau de recherches géologiques et minières.

England PC, Thompson AB. 1984. Pressure-temperature-time paths of regional metamorphism I. Heat transfer during the evolution of regions of thickened continental crust. J. Petrol. 25: 894-928.

Escher A, Beaumont C. 1997. Formation, burial and exhumation of basement nappes at crustal scale: a geometric model based on the Western Swiss-Italian Alps. J. Struct. Geol. 19: 955-974. https:// doi.org/10.1016/S0191-8141(97)00022-9.

Faure M. 1995. Late orogenic carboniferous extensions in the Variscan French Massif Central. Tectonics 14: 132-153.

Faure M, Pons J. 1991. Crustal thinning recorded by the shape of the Namurian-Westphalian leucogranite in the Variscan belt of the northwest Massif Central, France. Geology 19: 730. https://doi.org/ 10.1130/0091-7613(1991)019<0730:CTRBTS > 2.3.CO;2.

Faure M, Pin C, Mailhé D. 1979. Les roches mylonitiques associées au charriage du groupe leptyno-amphibolique sur les schistes du Lot dans la région de Marvejols (Lozère). CR Acad Sci Paris 288, 167-170.

Faure M, Prost AE, Lasne E. 1990. Déformation ductile extensive d'âge Namuro-Westphalien dans le plateau d'Aigurande, Massif central français. Bull. Société Géologique Fr. 6: 189-197.

Faure M, Grolier J, Pons J. 1993. Extensional ductile tectonics of the Sioule metamorphic series (Variscan French Massif Central). Geol. Rundsch. 82: 461-474.

Faure M, Leloix C, Roig J-Y. 1997. L'évolution polycyclique de la chaîne hercynienne. Bull. Société Géologique Fr. 168: 695-705.

Faure M, Charonnat X, Chauvet A. 1999. Structural map and tectonic evolution of the Cevennes para-autochthonous domain of the Hercynian belt (French Massif Central). Comptes Rendus Acad. Sci. Ser. II-A Earth Planet. Sci. 6: 401-407.

Faure M, Monié P, Pin C, Maluski H, Leloix C. 2002. Late Viséan thermal event in the northern part of the French Massif Central: new $40 \mathrm{Ar} / 39 \mathrm{Ar}$ and $\mathrm{Rb}-\mathrm{Sr}$ isotopic constraints on the Hercynian syn-orogenic extension. Int. J. Earth Sci. 91: 53-75. 
Faure M, Bé Mézème E, Cocherie A, Rossi P, Chemenda A, Boutelier D. 2008. Devonian geodynamic evolution of the Variscan Belt, insights from the French Massif Central and Massif Armoricain. Tectonics 27.

Faure M, Lardeaux J-M, Ledru P. 2009a. A review of the pre-Permian geology of the Variscan French Massif Central. Comptes Rendus Geosci. 341: 202-213.

Faure M, Mezeme EB, Cocherie A, Melleton J, Rossi P. 2009b. The South Millevaches Middle Carboniferous crustal melting and its place in the French Variscan belt. Bull. Société Géologique Fr. 180: 473-481.

Faure M, Cocherie A, Mézème EB, Charles N, Rossi P. 2010. Middle Carboniferous crustal melting in the Variscan Belt: New insights from $\mathrm{U}-\mathrm{Th}-\mathrm{Pbtot}$. monazite and $\mathrm{U}-\mathrm{Pb}$ zircon ages of the Montagne Noire Axial Zone (southern French Massif Central). Gondwana Res. 18: 653-673. https://doi.org/10.1016/j.gr.2010.02.005.

Faure M, Cocherie A, Gaché J, Esnault C, Guerrot C, Rossi P, et al. 2014. Middle Carboniferous intracontinental subduction in the Outer zone of the Variscan belt (Montagne Noire axial zone, French Massif Central): Multimethod geochronological approach of polyphase metamorphism. Geol. Soc. Lond. Spec. Publ. 405: 289-311.

Faure M, Li X-H, Lin W. 2017. The northwest-directed "Bretonian phase" in the French Variscan Belt (Massif Central and Massif Armoricain): A consequence of the Early Carboniferous Gondwana-Laurussia collision. Comptes Rendus Géoscience 349: 126136.

Faure M, Li X-H, Lin W. 2017. The northwest-directed "Bretonian phase" in the French Variscan Belt (Massif Central and Massif Armoricain): A consequence of the Early Carboniferous Gondwana-Laurussia collision. Comptes Rendus Géoscience 349: 126136.

Feist R, Galtier J. 1985. Découverte de flores d'âge namurien probable dans le flysch à olistolites de Cabrières (Hérault). Implication sur la durée de la sédimentation synorogénique dans la Montagne Noire (France méridionale). Comptes-Rendus Séances Académie Sci. Sér. 2 Mécanique-Phys. Chim. Sci. Univers Sci. Terre 300: 207-212.

Feybesse J-L. 1981. Tectonique de la région de Laroquebrou (Cantal, Massif Central français). Rôle de la déformation ductile et évolution du Sillon Houiller. Clermont-Ferrand.

Feybesse J-L, Lardeaux J-M, Johan V, Tegyey M, Dufour E, Lemiere B, et al. 1988. La série de la Brévenne (Massif central français): une unité dévonienne charriée sur le complexe métamorphique des Monts du Lyonnais à la fin de la collision varisque. Comptes Rendus Académie Sci. Sér. 2 Mécanique Phys. Chim. Sci. Univers Sci. Terre 307, 991-996.

Feybesse JL, Couturié JP, Ledru P, Johan, V. 1995. Les granites de la Margeride, de Chambon-le-Château et de Saint-Christophed'Allier (Massif Central) : des laccolites synchrones des derniers stades de l'épaississement varisque. Géologie Fr. 1: 27-45.

Floyd PA, Leveridge BE. 1987. Tectonic environment of the Devonian Gramscatho basin, south Cornwall: framework mode and geochemical evidence from turbiditic sandstones. J. Geol. Soc. 144: 531-542.

Forestier F-H. 1961. Métamorphisme hercynien et antéhercynien dans le bassin du Haut-Allier (Massif central français). Faculté des Sciences de l'Université de Clermont-Ferrand.

Fortey RA, Cocks LRM. 2003. Palaeontological evidence bearing on global Ordovician-Silurian continental reconstructions. Earth-Sci. Rev. 61: 245-307.

Foster DA, Schafer C, Fanning CM, Hyndman DW. 2001. Relationships between crustal partial melting, plutonism, orogeny, and exhumation: Idaho-Bitterroot batholith. Tectonophysics 342: 313-350.

Fowler MB, Henney PJ, Darbyshire DPF, Greenwood PB. 2001. Petrogenesis of high Ba-Sr granites: the Rogart pluton, Sutherland. J. Geol. Soc. 158: 521-534. https://doi.org/10.1144/jgs.158.3.521.

François T. 2009. Contraintes géochimiques et géochronologiques sur l'origine et la mise en place des granites du Mont Lozère (Master 2). Université Montpellier 2 Sciences et Techniques du Languedoc. Franke W. 1989. Variscan plate tectonics in Central Europe-Current ideas and open questions. Tectonophysics 169: 221-228.

Franke W. 2000. The mid-European segment of the Variscides: tectonostratigraphic units, terrane boundaries and plate tectonic evolution. Geol. Soc. Lond. Spec. Publ. 179: 35-61.

Franke W. 2014. Topography of the Variscan orogen in Europe: failed-not collapsed. Int. J. Earth Sci. 103: 1471-1499. https://doi. org/10.1007/s00531-014-1014-9.

Franke W, Engel W. 1986. Synorogenic sedimentation in the Variscan Belt of Europe. Bull. Société Géologique Fr. 2: 25-33.

Franke W, Doublier MP, Klama K, Potel S, Wemmer K. 2011. Hot metamorphic core complex in a cold foreland. Int. J. Earth Sci. 100: 753-785.

Franke W, Cocks LRM, Torsvik TH. 2017. The Palaeozoic Variscan oceans revisited. Gondwana Res. 48: 257-284. https://doi.org/ 10.1016/j.gr.2017.03.005.

Gaertner (Von) HR. 1937. Der bau des Französischen Zentralplateaus. Geol Rundsch 48-68.

Gardien V. 1990. Garnet and staurolite as relictual phases within the Low-Pressure facies series of the Pilat Unit (French Massif Central) - A record of polyphase tectonometamorphic reequilibration. Comptes Rendus Académie Sci. Sér. II 310: 233-240.

Gardien V. 1993. High to medium Pressure relics in the eastern Vivarais series (Eastern part of the French Massif-Central). Comptes Rendus Académie Sci. Sér. II 316: 1247-1254.

Gardien V, Lardeaux J-M. 1991. Découverte d'éclogites dans la synforme de Maclas: extension de l'unité supérieure des gneiss à l'Est du Massif Central. Comptes Rendus Académie Sci. Sér. 2 Mécanique Phys. Chim. Sci. Univers Sci. Terre 312: 61-68.

Gardien V, Lardeaux JM, Misseri M. 1988. The Monts du Lyonnais peridotites (MCF) - A record of Paleozoic upper mantle subduction. Comptes Rendus Acad. Sci. 307: 1967-1972.

Gardien V, Tegyey M, Lardeaux JM, Misseri M, Dufour E. 1990. Crust-mantle relationships in the French Variscan chain: the example of the Southern Monts du Lyonnais unit (eastern French Massif Central). J. Metamorph. Geol. 8: 477-492.

Gardien V, Thompson AB, Grujic D, Ulmer P. 1995. Experimental melting of biotite + plagioclase + quartz \pm muscovite assemblages and implications for crustal melting. J. Geophys. Res. Solid Earth 100: 15581-15591.

Gardien V, Lardeaux J-M, Ledru P, Allemand P, Guillot S. 1997. Metamorphism during late orogenic extension; insights from the French Variscan belt. Bull. Société Géologique Fr. 168: 271-286.

Gardien V, Vanderhaeghe O, Arnaud N, Cocherie A, Grange M, Lécuyer C. 2011. Thermal maturation and exhumation of a middle orogenic crust in the Livradois area (French Massif Central). Bull. Société Géologique Fr. 182: 5-24.

Gay M, Peterlongo JM, Caen-Vachette M. 1981. Age radiométrique des granites en massifs allongés et en feuillets minces syntectoniques dans les Monts du Lyonnais (Massif central français). CR Acad Sci Paris 293: 993-996.

Gay M, Briand B, Chenevoy M, Piboule M. 1982. Évolution structurale de la série métamorphique du Vivarais oriental (Massif central). Bull Bur Rech Geol Min Fr 3: 219-232. 
Gebauer D, Bernard-Griffiths J, Grünenfelder M. 1981. U-Pb zircon and monazite dating of a mafic-ultramafic complex and its country rocks. Contrib. Mineral. Petrol. 76: 292-300.

Gébelin A. 2004. Déformation et mise en place des granites (360$300 \mathrm{Ma}$ ) dans un segment de la chaîne Varisque (plateau de Millevaches, Massif Central). Université Montpellier II-Sciences et Techniques du Languedoc.

Gebelin A, Martelet G, Brunel M, Faure M, Rossi P. 2004. Late Hercynian leucogranites modelling as deduced from new gravity data: the example of the Millevaches massif (Massif Central, France). Bull. Société Géologique Fr. 175: 239-248.

Gébelin A, Martelet G, Chen Y, Brunel M, Faure M. 2006. Structure of late Variscan Millevaches leucogranite massif in the French Massif Central: AMS and gravity modelling results. J. Struct. Geol. 28: $148-169$.

Gébelin A, Brunel M, Monié P, Faure M, Arnaud N. 2007. Transpressional tectonics and Carboniferous magmatism in the Limousin, Massif Central, France: Structural and ${ }^{40} \mathrm{Ar} /{ }^{39} \mathrm{Ar}$ investigations. Tectonics 26.

Gébelin A, Roger F, Brunel M. 2009. Syntectonic crustal melting and high-grade metamorphism in a transpressional regime, Variscan Massif Central, France. Tectonophysics 477: 229-243.

Gerbault M, Martinod J, Hérail G. 2005. Possible orogeny-parallel lower crustal flow and thickening in the Central Andes. Tectonophysics 399: 59-72.

Gèze B. 1949. Etude géologique de la Montagne Noire et des Cévennes méridionales. Société géologique de France.

Gibson RL. 1991. Hercynian low-pressure-high-temperature regional metamorphism and subhorizontal foliation development in the Canigou massif, Pyrenees, France - Evidence for crustal extension. Geology 19: 380-383.

Girardeau J, Dubuisson G, Mercier J-CC. 1986. Cinématique de mise en place des ophiolites et nappes crystallophiliennes du Limousin, Ouest du Massif Central francais. Bull. Société Géologique Fr. 2: 849-860.

Gleizes G, Leblanc D, Bouchez JL. 1997. Variscan granites of the Pyrenees revisited: their role as syntectonic markers of the orogen. Terra Nova 9: 38-41. https://doi.org/10.1046/j.1365-3121.1997. d01-9.x.

Godard G. 1990. Découverte d'éclogites, de péridotites à spinelle et d'amphibolites à anorthite, spinelle et corindon dans le Morvan. Comptes Rendus Académie Sci. Sér. 2 Mécanique Phys. Chim. Sci. Univers Sci. Terre 310: 227-232.

Godard G. 2001. The Les Essarts eclogite-bearing metamorphic Complex (Vendée, Southern Armorican Massif, France). Géologie Fr. 1: 19-51.

Gordon SM, Whitney DL, Teyssier C, Fossen H, Kylander-Clark A. 2016. Geochronology and geochemistry of zircon from the northern Western Gneiss Region: Insights into the Caledonian tectonic history of western Norway. Lithos 246-247: 134-148. https://doi.org/10.1016/j.lithos.2015.11.036.

Gourgaud A. 1973. Granites et migmatites du Forez au sud de Montbrison. Université de Clermont Ferrand.

Grolier J, Letourneur J. 1968. L'évolution tectonique du grand Sillon Houiller du Massif Central francais, paper presented at XXIII International Geological Congress, Int. Union Geod Geophys, Florence, Italy.

Guergouz C, Martin L, Vanderhaeghe O, Thébaud N, Fiorentini M. 2018. Zircon and monazite petrochronologic record of prolonged amphibolite to granulite facies metamorphism in the Ivrea-Verbano and Strona-Ceneri Zones, NW Italy. Lithos 308-309: 1-18. https:// doi.org/10.1016/j.lithos.2018.02.014.
Guillot PL, Doubinger J. 1971. Découverte d'Acritarches dans les schistes sériciteux de Génis (Dordogne). C R Hebd Séanc Acad Sci Paris 272: 2763-2764.

Guillot PL, Lefevre J. 1975. Découvertes de conodontes dans le calcaire à entroques de Génis en Dordogne (série métamorphique du Bas-Limousin). Comptes Rendus L'Académie Sci. Paris D 280: 1529-1530.

Hamet J, Mattauer M. 1977. Age hercynien, déterminé par la méthode $\mathrm{Rb}-\mathrm{Sr}$ du granite de l'Aigoual, conséquences structurales. C R Somm Soc Géol Fr 2: 80-84.

Hamilton MA, Murphy JB. 2004. Tectonic significance of a Llanvirn age for the Dunn Point volcanic rocks, Avalon terrane, Nova Scotia, Canada: implications for the evolution of the Iapetus and Rheic oceans. Tectonophysics 379: 199-209.

Hanmer SK. 1977. Age and tectonic implications of the Baie d'Audierne basic-ultrabasic complex. Nature 270: 336.

Harrison TM, Watson EB. 1983. Kinetics of zircon dissolution and zirconium diffusion in granitic melts of variable water content. Contrib. Mineral. Petrol. 84: 66-72. https://doi.org/10.1007/BF01132331.

Hasalová P, Schulmann K, Lexa O, Štípská P, Hrouda F, Ulrich S, et al. 2008. Origin of migmatites by deformation-enhanced melt infiltration of orthogneiss: A new model based on quantitative microstructural analysis. J. Metamorph. Geol. 26: 29-53.

Hasalova P, Weinberg RF, MacRae C. 2011. Microstructural evidence for magma confluence and reusage of magma pathways: implications for magma hybridization, Karakoram Shear Zone in NW India. J. Metamorph. Geol. 29: 875-900.

Heilimo E, Halla J, Hölttä P. 2010. Discrimination and origin of the sanukitoid series: Geochemical constraints from the Neoarchean western Karelian Province (Finland). Lithos 115: 27-39. https:// doi.org/10.1016/j.lithos.2009.11.001.

Henk A. 2000. Foreland-directed lower-crustal flow and its implications for the exhumation of high-pressure-high-temperature rocks. Geol. Soc. Lond. Spec. Publ. 179: 355-368. https://doi.org/ 10.1144/GSL.SP.2000.179.01.21.

Henk A, von Blanckenburg F, Finger F, Schaltegger U, Zulauf G. 2000. Syn-convergent high-temperature metamorphism and magmatism in the Variscides: a discussion of potential heat sources. Geol. Soc. Lond. Spec. Publ. 179: 387-399. https://doi.org/ 10.1144/GSL.SP.2000.179.01.23.

Henry P, Le Pichon X, Goffé B. 1997. Kinematic, thermal and petrological model of the Himalayas: constraints related to metamorphism within the underthrust indian crust and topographic elevation. Tectonophysics 273: 31-56. https://doi.org/10.1016/ S0040-1951(96)00287-9.

Holliger P, Cuney M, Friedrich M, Turpin L. 1986. Age carbonifère de l'unité de Brame du complexe granitique peralumineux de SaintSylvestre (NO Massif Central) défini par les données isotopiques U-Pb sur zircon et monazite. Comptes Rendus Académie Sci. Sér. 2 Mécanique Phys. Chim. Sci. Univers Sci. Terre 303: 1309-1314.

Hottin A-M, Calvez JY. 1988. Résultats analytiques K-Ar et Rb-Sr sur quelques minéraux du forage de Sancerre-Couy. BRGM 137.

Houseman GA, McKenzie DP, Molnar P. 1981. Convective instability of a thickened boundary layer and its relevance for the thermal evolution of continental convergent belts. J. Geophys. Res. Solid Earth 86: 6115-6132.

Huerta AD, Royden LH, Hodges KV. 1996. The interdependence of deformational and thermal processes in mountain belts. Science 273: 637-639. https://doi.org/10.1126/science.273.5275.637.

Isnard H. 1996. Datation par la méthode U-Pb sur monazites des granites du Mont Lozère et de l'Est de la Margeride (laccolites de Chambon-le- Château et de St-Christophe d'Allier). 
Janousek V, Holub FV. 1997. Two distinct mantle sources of Hercynian magmas intruding the Moldanubian unit, Bohemian Massif, Czech Republic. J. Geosci. 42: 10-0.

Janoušek V, Braithwaite CJ, Bowes DR, Gerdes A. 2004. Magmamixing in the genesis of Hercynian calc-alkaline granitoids: an integrated petrographic and geochemical study of the Sázava intrusion, Central Bohemian Pluton, Czech Republic. Lithos 78: 67-99.

Joanny V, Lardeaux J-M, Trolliard G, Boudeulle M. 1989. La transition omphacite $\rightarrow$ diopside + plagioclase dans les éclogites du Rouergue (Massif Central Français): un exemple de précipitation discontinue. Comptes Rendus Académie Sci. Sér. 2 Mécanique Phys. Chim. Sci. Univers Sci. Terre 309: 1923-1930.

Joly A. 2007. Relations plutons et discontinuités lithosphériques: approche pluridisciplinaire de la mise en place de plutons granitiques le long du Sillon Houiller (Massif Central Français): apports des études de terrain et des données gravimétriques, magnétiques et ASM pour des modélisations 3D. PhD Thesis, Orléans.

Joly A, Martelet G, Chen Y, Faure M. 2008. A multidisciplinary study of a syntectonic pluton close to a major lithospheric-scale fault-Relationships between the Montmarault granitic massif and the Sillon Houiller Fault in the Variscan French Massif Central: 2. Gravity, aeromagnetic investigations, and 3-D geologic modelling. J. Geophys. Res. Solid Earth 113.

Joly A, Faure M, Martelet G, Chen Y. 2009. Gravity inversion, AMS and geochronological investigations of syntectonic granitic plutons in the southern part of the Variscan French Massif Central. J. Struct. Geol. 31: 421-443.

Jung J. 1953. Zoneographie et age des formations cristallophylliennes des massifs hercyniens francais [with discussion]. Bull. Société Géologique Fr. 6: 329-343.

Kelsey DE, Clark C, Hand M. 2008. Thermobarometric modelling of zircon and monazite growth in melt-bearing systems: Examples using model metapelitic and metapsammitic granulites. J. Metamorph. Geol. 26: 199-212.

Koné M. 1985. Mise en évidence de cisaillements ductiles tangentiel et décrochant dans le sud Livradois (Massif Central Français). Conséquences pour le "métamorphisme Livradois». Comptes Rendus Acad. Sci. 301: 189-193.

Kössler P, Tait J, Bachtadse V, Soffel HC, Linnemann U. 1996. Paleomagnetic investigations of Lower Paleozoic rocks of the Thüringer Schiefergebirge. Terra Nostra-Schriften Alfred-Wegener-Stift. 96: 115-116.

Kossmat F. 1927. Gliederung der varistischen Gebirgsbaues. Abh Sächs Geol Land 1-39.

Kosztolanyi C. 1971. Géochronologie des gisements uranifères français par la méthode uranium-plomb. Influence du déséquilibre radioactif sur les résultats. Université de Nancy 1.

Kroner U, Romer RL. 2013. Two plates - Many subduction zones: the Variscan orogeny reconsidered. Gondwana Res. 24, 298-329.

Kruckenberg SC, Vanderhaeghe O, Ferré EC, Teyssier C, Whitney DL. 2011. Flow of partially molten crust and the internal dynamics of a migmatite dome, Naxos, Greece: internal dynamics of the naxos dome. Tectonics 30. https://doi.org/10.1029/2010TC002751.

Kusbach V, Ulrich S, Schulmann K. 2012. Ductile deformation and rheology of sub-continental mantle in a hot collisional orogeny: Example from the Bohemian Massif. J. Geodyn. 56: 108-123.

Kusbach V, Janoušek V, Hasalová P, Schulmann K, Fanning CM, Erban V, et al. 2015. Importance of crustal relamination in origin of the orogenic mantle peridotite-high-pressure granulite association: example from the Náměšt' Granulite Massif (Bohemian Massif, Czech Republic). J. Geol. Soc. 172: 479-490.
Labrousse L, Prouteau G, Ganzhorn A-C. 2011. Continental exhumation triggered by partial melting at ultrahigh pressure. Geology 39: 1171-1174.

Lafon JM. 1986. Géochronologie U-Pb appliquée à deux segments du massif central français, le Rouergue oriental et le Limousin central (PhD Thesis).

Lafon J-M, Respaut J-P. 1988. Géochronologie U-Pb et leucogranites varisques: cas des massifs de Grandrieu (Lozère) et de la Porcherie (Limousin), Massif Central français. Bull. Minéralogie 111: 225 237.

Lagarde J-L, Dallain C, Ledru P, Courrioux G. 1994. Strain patterns within the late Variscan granitic dome of Velay, French Massif Central. J. Struct. Geol. 16: 839-852.

Lameyre J, Durandeau A, Laurent O, Sagon JP, Vauchelle L, Duzelier $\mathrm{D}$, et al. 1988. Démonstration, par sondage, de la présence du gneiss d'Aubusson sous les granites du batholite de Guéret (Massif Central français) et de la nature tectonique du contact. Comptes Rendus Académie Sci. Sér. 2 Mécanique Phys. Chim. Sci. Univers Sci. Terre 307: 2077-2083.

Lapierre H, Basile C, Berly T, Canard E. 2008. Potassic late orogenic Stephanian volcanism in the Southwest French Massif central (Decazeville, Figeac, Lacapelle-Marival basins): an example for mantle metasomatism along strike-slip faults? Bull. Société Géologique Fr. 179: 491-502.

Lardeaux J-M. 2014. Deciphering orogeny: a metamorphic perspective Examples from European Alpine and Variscan belts: Part II: Variscan metamorphism in the French Massif Central-A review. Bull. Soc. Geol. Fr. 185: 281-310. https://doi.org/10.2113/ gssgfbull.185.5.281.

Lardeaux J-M, Dufour E. 1987. Champs de déformation superposés dans la chaîne varisque. Exemple de la zone nord des Monts du Lyonnais (Massif central français). Comptes Rendus Académie Sci. Sér. 2 Mécanique Phys. Chim. Sci. Univers Sci. Terre 305: 61-64.

Lardeaux JM, Ledru P, Daniel I, Duchene S. 2001. The Variscan French Massif Central - a new addition to the ultra-high pressure metamorphic "club": exhumation processes and geodynamic consequences. Tectonophysics 332: 143-167.

Lardeaux JM, Schulmann K, Faure M, Janoušek V, Lexa O, Skrzypek E, et al. 2014. The moldanubian zone in the French Massif Central, Vosges/Schwarzwald and Bohemian Massif revisited: differences and similarities. Geol. Soc. Lond. Spec. Publ. 405: 7-44.

Lasnier B. 1968. Découverte de roches éclogitiques dans le groupe leptyno-amphibolique des monts du Lyonnais (Massif central français). Bull. Société Géologique Fr. 7: 179-185.

Lasnier B. 1971. Les peridotites et pyroxenolites a grenat du Bois des Feuilles (Monts du Lyonnais) (France). Contrib. Mineral. Petrol. 34: 29-42.

Lasserre M, Tempier P, Philibert J. 1980. Géochronologie Rb/Sr d'une intrusion cambrienne de la région de Saint-Flour (Massif Central français). Comptes Rendus Académie Sci. 737-740.

Laumonier B, Marignac C, Kister P. 2010. Polymetamorphism and crustal evolution of the eastern Pyrenees during the Late Carboniferous Variscan orogenesis. Bull. Soc. Geol. Fr. 181: 411-428. https://doi.org/10.2113/gssgfbull.181.5.411.

Laurent O, Martin H, Doucelance R, Moyen J-F, Paquette J-L. 2011. Geochemistry and petrogenesis of high-K "sanukitoids" from the Bulai pluton, Central Limpopo Belt, South Africa: Implications for geodynamic changes at the Archaean-Proterozoic boundary. Lithos 123: 73-91. https://doi.org/10.1016/j.lithos.2010.12.009.

Laurent O, Rapopo M, Stevens G, Moyen JF, Martin H, Doucelance $\mathrm{R}$, et al. 2014. Contrasting petrogenesis of $\mathrm{Mg}-\mathrm{K}$ and $\mathrm{Fe}-\mathrm{K}$ granitoids and implications for post-collisional magmatism: Case study from the Late-Archean Matok pluton (Pietersburg block, 
South Africa). Lithos 196-197: 131-149. https://doi.org/10.1016/j. lithos.2014.03.006.

Laurent O, Couzinié S, Zeh A, Vanderhaeghe O, Moyen J-F, Villaros A, et al. 2017. Protracted, coeval crust and mantle melting during Variscan late-orogenic evolution: U-Pb dating in the eastern French Massif Central. Int. J. Earth Sci. 106: 421-451.

Le Breton N, Duthou J-L, Grolier J, Lacour A, Meyer G, Treuil M. 1986. Les diatexites à cordiérite d'Aubusson (Creuse, France): pétrographie, composition, âge. Comptes Rendus Académie Sci. Sér. 2 Mécanique Phys. Chim. Sci. Univers Sci. Terre 303: 15571562.

Le Corre C, Auvray B, Ballevre M, Robardet M. 1991. Le Massif Armoricain / The Armorican Massif. Sci. Géologiques Bull. 44: 31-103. https://doi.org/10.3406/sgeol.1991.1865.

Ledru P, Autran A. 1987. L'édification de la chaîne varisque dans le Limousin, rôle de la faille d'Argentat à la limite LimousinMillevaches. Géol Prof Fr. Thème 3: 51-91.

Ledru P, Marot A, Herrouin Y. 1986. Le synclinorium de SaintGeorges-sur-Loire: une unité ligérienne charriée sur le domaine centre armoricain. Découverte de métabasite à glaucophane sur la bordure sud de cette unité. Comptes Rendus Académie Sci. Sér. 2 Mécanique Phys. Chim. Sci. Univers Sci. Terre 303: 963-968.

Ledru P, Lardeaux J-M, Santallier D, Autran A, Quenardel JM, Floc'h JP, et al. 1989. Où sont les nappes dans le Massif central français? Bull. Société Géologique Fr. 605-618.

Ledru P, Costa S, Echtler H. 1994. The massif central: structure. PreMesoz. Geol. Fr. Relat. Areas 305-323.

Ledru P, Courrioux G, Dallain C, Lardeaux JM, Montel JM, Vanderhaeghe O, et al. 2001. The Velay dome (French Massif Central): melt generation and granite emplacement during orogenic evolution. Tectonophysics 342: 207-237.

Legendre C, Briand B, Thierry J, Lebret P, Joly A, Bertin C. 2009. Notice explicative de la carte géologique de Saint-Geniez-d'Olt (861) au 1/50 000. Éditions BRGM Orléans.

Leloix C, Faure M, Feybesse J-L. 1999. Hercynian polyphase tectonics in the northeast French Massif Central: the closure of the Brévenne Devonian-Dinantian rift. Int. J. Earth Sci. 88: 409-421.

Lenoir X, Garrido CJ, Bodinier J-L, Dautria J-M. 2000. Contrasting lithospheric mantle domains beneath the Massif Central (France) revealed by geochemistry of peridotite xenoliths. Earth Planet. Sci. Lett. 181: 359-375. https://doi.org/10.1016/S0012-821X(00) 00216-8.

Lerouge G, Quenardel J-M. 1988. Les zones de cisaillement carboniferes dans les plutons vendeens et leurs prolongations dans le Nord-ouest du Masif central francais. Bull. Société Géologique Fr. 4: 831-838.

Lescuyer J-L, Cocherie A. 1992. Datation sur monozircons des métadacites de Sériès: arguments pour un âge protérozoïque terminal des schistes X de la Montagne Noire (Massif central français). Comptes Rendus Académie Sci. Sér. 2 Mécanique Phys. Chim. Sci. Univers Sci. Terre 31: 1071-1077.

Letterrier J. 1978. Aspects chimiques des interactons entre les magmas basiques et leur encaissant pelitique dans le plutonisme. Bull. Société Géologique Fr. 7: 21-28.

Lexa O, Schulmann K, Janoušek V, Štípská P, Guy A, Racek M. 2011. Heat sources and trigger mechanisms of exhumation of HP granulites in Variscan orogenic root. J. Metamorph. Geol. 29: 79102.

Leyreloup A. 1974. Les enclaves catazonales remontées par les éruptions néogènes de France: nature de la croûte inférieure. Contrib. Mineral. Petrol. 46: 17-27.

Linnemann U, Gerdes A, Drost K, Buschmann B. 2007. The continuum between Cadomian orogenesis and opening of the Rheic
Ocean: Constraints from LA-ICP-MS U-Pb zircon dating and analysis of plate-tectonic setting (Saxo-Thuringian zone, northeastern Bohemian Massif, Germany). Spec. Pap.-Geol. Soc. Am. 423: 61.

Lister GS, Baldwin SL. 1993. Plutonism and the origin of metamorphic core complexes. Geology 21: 607-610.

Lotout C, Pitra P, Poujol M, Van Den Driessche J. 2017. Ordovician magmatism in the Lévézou massif (French Massif Central): tectonic and geodynamic implications. Int. J. Earth Sci. 106: 501515.

Lotout C, Pitra P, Poujol M, Anczkiewicz R, Van Den Driessche J. 2018. Timing and duration of Variscan high-pressure metamorphism in the French Massif Central: A multimethod geochronological study from the Najac Massif. Lithos 308: 381-394.

Maillet N, Piboule M, Santallier D, Cabanis B. 1984. Diversité d'origine des ultrabasites dans la série métamorphique du Limousin. BRGM 81: 1-24.

Malavieille J. 2010. Impact of erosion, sedimentation, and structural heritage on the structure and kinematics of orogenic wedges: Analog models and case studies. GSA Today 4-10. https://doi.org/ 10.1130/GSATG48A.1.

Malavieille J, Guihot P, Costa S, Lardeaux JM, Gardien V. 1990. Collapse of the thickened Variscan crust in the French Massif Central: Mont Pilat extensional shear zone and St. Etienne Late Carboniferous basin. Tectonophysics 177: 139-149.

Maluski H, Monié P. $1988 .{ }^{40} \mathrm{Ar}-{ }^{39} \mathrm{Ar}$ laser probe multi-dating inside single biotites of a Variscan orthogeneiss (Pinet, Massif Central, France). Chem. Geol. Isot. Geosci. Sect. 73: 245-263.

Maluski H, Costa S, Echtler H. 1991. Late variscan tectonic evolution by thinning of earlier thickened crust. $\mathrm{An}{ }^{40} \mathrm{Ar} /{ }^{39} \mathrm{Ar}$ study of the Montagne Noire, southern Massif Central, France. Lithos 26: 287 304.

Marchand J. 1981. Ecaillage d'un «mélange tectonique» profond : le complexe cristallophyllien de Champtoceaux (Bretagne méridionale). CR Acad Sci Paris 293: 223-228.

Marignac C, Leroy J, Macaudière J, Pichavant M, Weisbrod A. 1980. Evolution tectonométamorphique d'un segment de l'orogène hercynien: les Cévennes médianes, Massif central français. CR Acad Sci Paris 291: 605-608.

Martin H, Smithies RH, Rapp R, Moyen J-F, Champion D. 2005. An overview of adakite, tonalite-trondhjemite-granodiorite (TTG), and sanukitoid: relationships and some implications for crustal evolution. Lithos 79: 1-24. https://doi.org/10.1016/j.lith os.2004.04.048.

Martínez Catalán JR, Arenas R, García FD, Cuadra PG, GómezBarreiro J, Abati J, et al. 2007. Space and time in the tectonic evolution of the northwestern Iberian Massif: Implications for the Variscan belt. In: Geological Society of America Memoirs. Geological Society of America, pp.403-423. https://doi.org/ 10.1130/2007.1200(21).

Martínez Catalán JR, Arenas R, Abati J, Martínez SS, García FD, Suárez JF, et al. 2009. A rootless suture and the loss of the roots of a mountain chain: The Variscan belt of NW Iberia. Comptes Rendus Geosci. 341: 114-126. https://doi.org/10.1016/j.crte.2008.11.004.

Mattauer M, Etchecopar A. 1976. Arguments en faveur de chevauchements de type himalayen dans la chaîne hercynienne du Massif Central français. Coll Int CNRS Paris 268: 261-267.

Mattauer M, Laurent P, Matte P. 1996. Plissement hercynien synschisteux post-nappe et étirement subhorizontal dans le versant sud de la Montagne noire (Sud du Massif central, France). Comptes Rendus Académie Sci. Sér. 2 Sci. Terre Planètes 322: 309-315.

Matte P. 1986. Tectonics and plate tectonics model for the Variscan belt of Europe. Tectonophysics 126: 329-374. 
Matte P. 1991. Accretionary history and crustal evolution of the Variscan belt in Western Europe. Tectonophysics 196: 309-337. https://doi.org/10.1016/0040-1951(91)90328-P.

Matte P. 2001. The Variscan collage and orogeny (480-290 Ma) and the tectonic definition of the Armorica microplate: a review. Terra Nova 13: 122-128.

Matte P, Lancelot J, Mattauer M. 1998. La zone axiale hercynienne de la Montagne Noire n'est pas un "metamorphic core complex" extensif mais un anticlinal post-nappe à coeur anatectique. Geodin. Acta 11: 13-22.

Maurel O, Monié P, Respaut JP, Leyreloup AF, Maluski H. 2003. Premetamorphic 40Ar/39Ar and U-Pb ages in $\mathrm{HP}$ metagranitoids from the Hercynian belt (France). Chem. Geol. 193: 195-214.

McCarthy A, Chelle-Michou C, Müntener O, Arculus R, Blundy J. 2018. Subduction initiation without magmatism: The case of the missing Alpine magmatic arc. Geology 46: 1059-1062. https://doi. org/10.1130/G45366.1.

Melleton J, Faure M, Cocherie A. 2009. Monazite U-Th/Pb chemical dating of the Early Carboniferous syn-kinematic MP/MT metamorphism in the Variscan French Massif Central. Bull. Société Géologique Fr. 180: 283-292.

Melleton J, Cocherie A, Faure M, Rossi P. 2010. Precambrian protoliths and Early Paleozoic magmatism in the French Massif Central: U-Pb data and the North Gondwana connection in the west European Variscan belt. Gondwana Res. 17: 13-25.

Ménard G, Molnar P. 1988. Collapse of a Hercynian Tibetan plateau into a late Palaeozoic European Basin and Range province. Nature 334: 235.

Mercier JCC, Girardeau J, Prinzhofer A, Dubuisson G. 1985. Les complexes ophiolitiques du Limousin: structure, pétrologie et géochimie. Rapp. GPF2 Thème 3: 95-3.

Mercier L, Lardeaux J-M, Davy P. 1991a. On the tectonic significance of retrograde P-T-t paths in eclogites of the French Massif Central. Tectonics 10: 131-140.

Mercier L, Van Roermund HLM, Lardeaux JM. 1991b. Comparison of PTt paths in allochthonous high pressure metamorphic terrains from the Scandinavian Caledonides and the french Massif Central: contrasted thermal structures during uplift. Geol. Rundsch. 80: 333-348.

Mialhe J. 1980. Le massif granitique de la Borne (Cévennes). Etude pétrographique, géochimique, géochronologique et structurale (Doctorat). Université de Clermont Ferrand.

Michon G. 1987. Les vaugnerites de l'Est du Massif central français : apport de l'analyse statistique multivariée à l'étude géochimique des éléments majeurs. Bull. Soc. Geol. Fr. 8: 591-600.

Milési J-P, Lescuyer J-L. In press. The chessy zn-Cu-ba massive sulphide deposit and the Devonian brevenne volcanosedimentary belt (eastern massif central, France). BRGM.

Mollier B, Bouchez JL. 1982. Structuration magmatique du complexe granitique de Brâme-St Sylvestre-St Goussaud (Limousin, Massif Central Français). CR Acad Sci Ser 2 294: 1329-1334.

Molnar P, Lyon-Caen H. 1988. Some simple physical aspects of the support, structure, and evolution of mountain belts. In: Geological Society of America Special Papers. Geological Society of America, pp. 179-208. https://doi.org/10.1130/SPE218-p179.

Molnar P, England P, Martinod J. 1993. Mantle dynamics, uplift of the Tibetan Plateau, and the Indian Monsoon. Rev. Geophys. 31: 357. https://doi.org/10.1029/93RG02030.

Monié P, Respaut JP, Brichau S, Bouchot V, Faure M, Roig JY. 2000. ${ }^{40} \mathrm{Ar} /{ }^{39} \mathrm{Ar}$ and $\mathrm{U}-\mathrm{Pb}$ geochronology applied to $\mathrm{Au}-\mathrm{W}-\mathrm{Sb}$ metallogenesis in the Cévennes and Châtaigneraie districts (Southern Massif Central, France). Orog. Gold Depos. Eur. Doc BRGM 297: 77-79.
Monier G. 1980. Pétrologie des granites du Sud-Millevaches (MCF). Minéralogie, géochimie, géochronologie (Doctorat $3^{\mathrm{e}}$ Cycle). Université de Clermont Ferrand.

Montel J-M. 1985. Xénolithes peralumineux dans les dolérites du Peyron, en Velay (Massif Central, France). Indications sur l'évolution de la croute profonde tardihercynienne. Comptes Rendus Académie Sci. Sér. 2 Mécanique Phys. Chim. Sci. Univers Sci. Terre 301: 615-620.

Montel JM, Abdelghaffar R. 1993. Les granites tardi-migmatitiques du Velay (Massif Central) : principales caractéristiques pétrographiques et géochimiques. Géologie Fr. 1: 15-28.

Montel JM, Marignac C, Barbey P, Pichavant M. 1992. Thermobarometry and granite genesis: the Hercynian low-P, high-T Velay anatectic dome (French Massif Central). J. Metamorph. Geol. 10: $1-15$.

Montel J-M, Bouloton J, Veschambre M, Pellier C, Ceret K. 2002. Âges stéphaniens des microgranites du Velay (Massif central français). Géologie Fr. 15-20.

Mougeot R, Respaut J-P, Ledru P, Marignac C. 1997. U-Pb chronology on accessory minerals of the Velay anatectic dome (French Massif Central). Eur. J. Mineral. 9: 141-156.

Moyen J-F, Laurent O, Chelle-Michou C, Couzinié S, Vanderhaeghe O, Zeh A. 2017. Collision vs. subduction-related magmatism: two contrasting ways of granite formation and implications for crustal growth. Lithos 277: 154-177.

Murphy JB, Gutierrez-Alonso G, Nance RD, Fernandez-Suarez J, Keppie JD, Quesada C, et al. 2006. Origin of the Rheic Ocean: Rifting along a Neoproterozoic suture? Geology 34: 325-328.

Nance RD, Gutiérrez-Alonso G, Keppie JD, Linnemann U, Murphy JB, Quesada C, et al. 2010. Evolution of the Rheic ocean. Gondwana Res. 17: 194-222.

Nicolas A, Bouchez JL, Blaise J, Poirier JP. 1977. Geological aspects of deformation in continental shear zones. Tectonophysics 42 : $55-73$.

Nicollet C. 1977. Une nouvelle éclogite à disthène et corindon primaires dans les complexes leptyno-amphiboliques du Massif central français (Lévezou, Rouergue). Bull Soc Fr Miner. Cristal. 100: 334-337.

Nicollet C. 1978. Pétrologie et tectonique des terrains cristallins antépermiens du versant sud du dôme du Lévezou (Rouergue, Massif central). Bull BRGM 3: 225-263.

Nicollet C, Leyreloup A. 1978. Pétrologie des niveaux trondhjémitiques de haute pression associés aux éclogites et amphibolites des complexes leptyno-amphiboliques du Massif Central français. Can. J. Earth Sci. 15: 696-707.

O’Brien PJ, Rötzler J. 2003. High-pressure granulites: formation, recovery of peak conditions and implications for tectonics. J. Metamorph. Geol. 21: 3-20.

Pagel M, Costa S, Galibert F, Lancelot J, Maluski H, Meyer A, et al. 1992. Forage scientifique de Sancerre-Couy: Géochronologie Sm$\mathrm{Nd}, \mathrm{U}-\mathrm{Pb}, \mathrm{Ar}-\mathrm{Ar}, \mathrm{Rb}-\mathrm{Sr}$ et chronométrie par traces de fission sur le socle. Géologie Fr. 3: 129.

Paquette J-L, Monchoux P, Couturier M. 1995. Geochemical and isotopic study of a norite-eclogite transition in the European Variscan belt: Implications for $\mathrm{U} / \mathrm{Pb}$ zircon systematics in metabasic rocks. Geochim. Cosmochim. Acta 59: 1611-1622.

Paquette J-L, Ballèvre M, Peucat J-J, Cornen G. 2017. From opening to subduction of an oceanic domain constrained by LA-ICP-MS $\mathrm{U}-\mathrm{Pb}$ zircon dating (Variscan belt, Southern Armorican Massif, France). Lithos 294: 418-437.

Paris F, Robardet M. 1990. Early Palaeozoic palaeobiogeography of the Variscan regions. Tectonophysics 177: 193-213. 
Peiffer M-T. 1986. La signification de la ligne tonalitique du Limousin. Son implication dans la structuration varisque du Massif Central français. Comptes Rendus Académie Sci. Sér. 2 Mécanique Phys. Chim. Sci. Univers Sci. Terre 303: 305-310.

Perchuk LL, Podladchikov YY, Polyakov AN. 1992. Hydrodynamic modelling of some metamorphic processes. J. Metamorph. Geol. 10: 311-319. https://doi.org/10.1111/j.1525-1314.1992.tb00086.x.

Percival JA. 1992. Exposed crustal cross sections as windows on the lower crust. Cont. Low. Crust Dev. Geotecton. 317-362.

Petitpierre E, Duthou JL. 1980. Age westphalien par la méthode $\mathrm{Rb} / \mathrm{Sr}$ du leucogranite de Crevant, Plateau d'Aigurande (Massif Central français). CR Acad Sci 291: 163-166.

Piboule M, Briand B. 1985. Geochemistry of eclogites and associated rocks of the southeastern area of the French Massif Central: origin of the protoliths. Chem. Geol. 50: 189-199.

Pin C. 1979. Géochronologie U-Pb et microtectonique des séries métamorphiques anté-stéphaniennes de l'Aubrac et de la région de Marvejols (Massif Central). PhD Thesis, Université Montpellier IISciences et Techniques du Languedoc.

Pin C. 1981. Old inherited zircons in two synkinematic variscan granitoids: the'granite du Pinet'and the'Orthogneiss de Marvejols'(Southern French Massif Central). Neues Jahrb. Für Mineral. Abh. 142: 27-48.

Pin C. 1990. Variscan oceans: ages, origins and geodynamic implications inferred from geochemical and radiometric data. Tectonophysics 177: 215-227.

Pin C, Duthou J-L. 1990. Sources of Hercynian granitoids from the French Massif Central: Inferences from $\mathrm{Nd}$ isotopes and consequences for crustal evolution. Chem. Geol. 83: 281-296. https://doi.org/10.1016/0009-2541(90)90285-F.

Pin C, Lancelot JR. 1978. Un exemple de magmatisme cambrien dans le Massif central; les metadiorites quartziques intrusives dans la serie du Lot. Bull. Société Géologique Fr. 7: 203-208.

Pin C, Lancelot J. 1982. U-Pb dating of an early Paleozoic bimodal magmatism in the French Massif Central and of its further metamorphic evolution. Contrib. Mineral. Petrol. 79: 1-12.

Pin C, Marini F. 1993. Early Ordovician continental break-up in Variscan Europe: $\mathrm{Nd} \mathrm{Sr}$ isotope and trace element evidence from bimodal igneous associations of the Southern Massif Central, France. Lithos 29: 177-196.

Pin C, Paquette J-L. 1997. A mantle-derived bimodal suite in the Hercynian Belt: $\mathrm{Nd}$ isotope and trace element evidence for a subduction-related rift origin of the Late Devonian Brévenne metavolcanics, Massif Central (France). Contrib. Mineral. Petrol. 129: 222-238.

Pin C, Paquette JL. 2002. Sr-Nd isotope and trace element evidence for a Late Devonian active margin in northern Massif-Central (France). Geodin. Acta 15: 63-77.

Pin C, Vielzeuf D. 1983. Granulites and related rocks in Variscan median Europe: a dualistic interpretation. Tectonophysics 93: 4774.

Pitra P, Poujol M, Van Den Driessche J, Poilvet J-C, Paquette J-L. 2012. Early Permian extensional shearing of an ordovician granite: The saint-eutrope "c/s-like" orthogneiss (montagne noire, French massif central). Comptes Rendus Géoscience 344: 377-384.

Poilvet J-C, Poujol M, Pitra P, Van den Driessche J, Paquette J-L. 2011. The Montalet granite, Montagne Noire, France: An Early Permian syn-extensional pluton as evidenced by new $\mathrm{U}-\mathrm{Th}-\mathrm{Pb}$ data on zircon and monazite. Comptes Rendus Géoscience 343: 454 461.

Prelević D, Akal C, Foley SF, Romer RL, Stracke A, Van Den Bogaard P. 2012. Ultrapotassic Mafic Rocks as Geochemical Proxies for Post-collisional Dynamics of Orogenic Lithospheric
Mantle: the Case of Southwestern Anatolia, Turkey. J. Petrol. 53: 1019-1055. https://doi.org/10.1093/petrology/egs008.

Quenardel J-M, Rolin P. 1984. Palaeozoic evolution of the Plateau d'Aigurande (NW Massif Central, France). Geol. Soc. Lond. Spec. Publ. 14: 63-70.

Quenardel J-M, Santallier D, Burg J-P, Bril H, Cathelineau M, Marignac C. 1991. Le Massif Central / The central massif. Sci. Géologiques Bull. 44: 105-206. https://doi.org/10.3406/ sgeol.1991.1866.

Rabin M, Trap P, Carry N, Fréville K, Cenki-Tok B, Lobjoie C, et al. 2015. Strain partitioning along the anatectic front in the Variscan Montagne Noire massif (southern French Massif Central). Tectonics 34: 1709-1735.

Ramberg H. 1968. Fluid dynamics of layered systems in the field of gravity, a theoretical basis for certain global structures and isostatic adjustment. Phys. Earth Planet. Inter. 1: 63-87. https://doi.org/ 10.1016/0031-9201(68)90051-4.

Rapp RP, Norman MD, Laporte D, Yaxley GM, Martin H, Foley SF. 2010. Continent Formation in the Archean and Chemical Evolution of the Cratonic Lithosphere: Melt-Rock Reaction Experiments at 3$4 \mathrm{GPa}$ and Petrogenesis of Archean Mg-Diorites (Sanukitoids). $J$. Petrol. 51: 1237-1266. https://doi.org/10.1093/petrology/egq017.

Ravier J, Chenevoy M. 1979. Occurence of granulitic formations denoting the presence of a crustal lineament in the Sioule metamorphic series (Massif Central Français). Comptes Rendus Hebd. Séances Académie Sci. Sér. D 288: 1703-1706.

Respaut J-P. 1984. Géochronologie et géochimie isotopique U-Pb de la minéralisation aurifère de la mine des Pierres Plantées (Lozère) et de son encaissant: le massif granitique de la Margeride. Montpellier.

Rey P, Vanderhaeghe O, Teyssier C. 2001. Gravitational collapse of the continental crust: definition, regimes and modes. Tectonophysics 342: 435-449. https://doi.org/10.1016/S0040-1951(01)001743.

Rey PF, Teyssier C, Whitney DL. 2009. The role of partial melting and extensional strain rates in the development of metamorphic core complexes. Tectonophysics 477: 135-144. https://doi.org/ 10.1016/j.tecto.2009.03.010.

Rey PF, Teyssier C, Kruckenberg SC, Whitney DL. 2011. Viscous collision in channel explains double domes in metamorphic core complexes. Geology 39: 387-390.

R'Kha Chaham K, Couturie J-P, Duthou J-L, Fernandez A, Vitel G. 1990. L'orthogneiss ø eillé de l'Arc de Fix : un nouveau témoin d'âge cambrien d'un magmatisme hyper alumineux dans le Massif Central français. Comptes Rendus Académie Sci. Sér. 2 Mécanique Phys. Chim. Sci. Univers Sci. Terre 311: 845-850.

Robardet M. 2003. The Armorica "microplate": fact or fiction? Critical review of the concept and contradictory palaeobiogeographical data. Palaeogeogr. Palaeoclimatol. Palaeoecol. 195: 125-148.

Robardet M, Blaise J, Bouyx E, Gourvennec R, Lardeux H, Le Herisse A, et al. 1993. Paléogéographie de l'Europe occidentale de l'Ordovicien au Dévonien = Palaeogeography of Western Europe from the Ordovician to the Devonian. Bull. Société Géologique Fr.

Roger F, Respaut J-P, Brunel M, Matte P, Paquette J-L. 2004. Première datation $\mathrm{U} / \mathrm{Pb}$ des orthogneiss ø eillés de la zone axiale de la Montagne noire (Sud du Massif central) : nouveaux témoins du magmatisme ordovicien dans la chaîne Varisque. Comptes Rendus Geosci. 336: 19-28.

Roger F, Teyssier C, Respaut J-P, Rey PF, Jolivet M, Whitney DL, et al. 2015. Timing of formation and exhumation of the Montagne Noire double dome, French Massif Central. Tectonophysics 640: 53-69. 
Roig J-Y, Faure M. 2000. La tectonique cisaillante polyphasee du Sud Limousin (Massif central francais) et son interpretation dans un modele d'evolution polycyclique de la chaine hercynienne. Bull. Société Géologique Fr. 171: 295-307.

Roig J-Y, Faure M, Ledru P. 1996. Polyphase wrench tectonics in the southern french Massif Central: kinematic inferences from pre-and syntectonic granitoids. Geol. Rundsch. 85: 138-153.

Roig J-Y, Faure M, Maluski H. 2002. Superimposed tectonic and hydrothermal events during the late-orogenic extension in the Western French Massif Central: a structural and 40Ar/39Ar study. Terra Nova 14: 25-32.

Rolin P, Duthou JL, Quenardel JM. 1982. Datation Rb/Sr des leucogranites de Crozant et d'Orsennes : Conséquences sur l'âge de la derniere phase de tectonique tangentielle du Plateau d'Aigurande (NW du Massif Central Français). CR Acad Sci Ser II 294: 799802.

Rolin P, Marquer D, Colchen M, Cartannaz C, Cocherie A, Thiery V, et al. 2009. Famenno-Carboniferous (370-320 Ma) strike slip tectonics monitored by syn-kinematic plutons in the French Variscan belt (Massif Armoricain and French Massif Central). Bull. Société Géologique Fr. 180: 231-246.

Rolin P, Marquer D, Cartannaz C, Rossi P. 2014. Carboniferous magmatism related to progressive pull-apart opening in the western French Massif Central. Bull. Société Géologique Fr. 185: 171-189.

Roques M. 1971. Structure géologique du Massif central. In: Géologie, géomorphologie et structure profonde du Massif Central Français. Symp J Jung, Clermont-Ferrand, pp. 17-32.

Rosenberg CL. 2001. Deformation of partially molten granite: a review and comparison of experimental and natural case studies. Int. J. Earth Sci. 90: 60-76.

Royden L. 1996. Coupling and decoupling of crust and mantle in convergent orogens: Implications for strain partitioning in the crust. J. Geophys. Res. Solid Earth 101: 17679-17705. https://doi. org/10.1029/96JB00951.

Royden LH. 1997. Surface deformation and Lower Crustal Flow in Eastern Tibet. Science 276: 788-790. https://doi.org/10.1126/ science.276.5313.788.

Rubio Pascual FJ, López-Carmona A, Arenas R. 2016. Thickening vs. extension in the Variscan belt: P-T modelling in the Central Iberian autochthon. Tectonophysics 681: 144-158. https://doi.org/10.1016/ j.tecto.2016.02.033.

Sabatier H. 1991. Vaugnerites: special lamprophyre-derived mafic enclaves in some Hercynian granites from Western and Central Europe. Enclaves Granite Petrol. Elsevier Amst. 63-81.

Saint-Joanis R. 1975. Étude géologique du socle cristallin du BasLivradois (Massif central français) dans le périmètre de la feuille d'Issoire. Université Blaise Pascal, Clermont-Ferrand.

Sandiford M, Powell R. 1990. Some isostatic and thermal consequences of the vertical strain geometry in convergent orogens. Earth Planet. Sci. Lett. 98: 154-165. https://doi.org/ 10.1016/0012-821X(90)90056-4.

Santallier D. 1981. Les roches basiques dans la série métamorphique du Bas-Limousin, Massif Central (France) (PhD Thesis).

Santallier D, Briand B, Menot RP, Piboule M. 1988. Les complexes leptyno-amphiboliques (CLA) : revue critique et suggestions pour un meilleur emploi de ce terme. Bull. Société Géologique Fr. 4: 3-12.

Sawyer EW. 1994. Melt segregation in the continental crust. Geology 22: 1019-1022.

Sawyer EW. 1998. Formation and evolution of granite magmas during crustal reworking: the significance of diatexites. J. Petrol. 39: 1147-1167.

Sawyer EW, Cesare B, Brown M. 2011. When the continental crust melts. Elements 7: 229-234.
Schaltegger U, Gebauer D. 1999. Pre-Alpine geochronology of the central, western and southern Alps. Schweiz. Mineral. Petrogr. Mitteilungen 79: 79-87.

Schenk V. 1980. U-Pb and $\mathrm{Rb}-\mathrm{Sr}$ radiometric dates and their correlation with metamorphic events in the granulite-facies basement of the Serre, southern Calabria (Italy). Contrib. Mineral. Petrol. 73: 23-38.

Schenk V. 1981. Synchronous uplift of the lower crust of the Ivrea Zone and of southern Calabria and its possible consequences for the Hercynian orogeny in southern Europe. Earth Planet. Sci. Lett. 56: 305-320.

Schenk V. 1989. PTt path of the lower crust in the Hercynian fold belt of southern Calabria. Geol. Soc. Lond. Spec. Publ. 43: 337-342.

Schulmann K, Lexa O, Štípská P, Racek M, Tajčmanová L, Konopásek J, et al. 2008. Vertical extrusion and horizontal channel flow of orogenic lower crust: key exhumation mechanisms in large hot orogens? J. Metamorph. Geol. 26: 273-297.

Schulmann K, Konopásek J, Janoušek V, Lexa O, Lardeaux J-M, Edel J-B, et al. 2009. An Andean type Palaeozoic convergence in the Bohemian massif. Comptes Rendus Geosci. 341: 266-286.

Schulmann K, Catalán JRM, Lardeaux JM, Janoušek V, Oggiano G. 2014. The Variscan orogeny: extent, timescale and the formation of the European crust. Geol. Soc. Lond. Spec. Publ. 405: 1-6.

Schulz B. 2009. EMP-monazite age controls on PT paths of garnet metapelites in the Variscan inverted metamorphic sequence of $\mathrm{La}$ Sioule, French Massif Central. Bull. Société Géologique Fr. 180: 271-282.

Schulz B. 2014. Early Carboniferous PT path from the Upper Gneiss Unit of Haut-Allier (French Massif Central)-reconstructed by geothermobarometry and EMP-Th- $\mathrm{U}-\mathrm{Pb}$ monazite dating. J. Geosci. 59: 327-349.

Schulz B, Triboulet C, Audren C, Feybesse J-L. 1996. Zoned garnets in metapelites and PT-deformation path interpretation of the Variscan inverted metamorphic sequence of Haut-Allier, French Massif Central. Z. Dtsch. Geol. Ges. 249-273.

Schulz B, Triboulet C, Audren C, Feybesse J-L. 2001. PT-paths from metapelite garnet zonations, and crustal stacking in the Variscan inverted metamorphic sequence of La Sioule, French Massif Central. Z. Dtsch. Geol. Ges. 152: 1-26.

Scotese CR, McKerrow WS. 1990. Revised world maps and introduction. Geol. Soc. Lond. Mem. 12: 1-21.

Searle MP, Cottle JM, Streule MJ, Waters DJ. 2009. Crustal melt granites and migmatites along the Himalaya: melt source, segregation, transport and granite emplacement mechanisms. Earth Environ. Sci. Trans. R. Soc. Edinb. 100: 219-233.

Shail RK, Leveridge BE. 2009. The Rhenohercynian passive margin of SW England: Development, inversion and extensional reactivation. Comptes Rendus Geosci. 341: 140-155.

Shaw J, Johnston ST. 2016. Terrane wrecks (coupled oroclines) and paleomagnetic inclination anomalies. Earth-Sci. Rev. 154: 191209.

Sider H, Ohnenstetter M. 1986. Field and petrological evidence for the development of an ensialic marginal basin related to the Hercynian orogeny in the Massif Central, France. Geol. Rundsch. 75: 421-443.

Sintubin M, Debacker TN, Van Baelen H. 2009. Early Palaeozoic orogenic events north of the Rheic suture (Brabant, Ardenne): A review. Comptes Rendus Geosci. 341: 156-173. https://doi.org/ 10.1016/j.crte.2008.11.012.

Skrzypek E, Tabaud A-S, Edel J-B, Schulmann K, Cocherie A, Guerrot C, et al. 2012. The significance of Late Devonian ophiolites in the Variscan orogen: a record from the Vosges Klippen Belt. Int. J. Earth Sci. 101: 951-972. 
Skrzypek E, Schulmann K, Tabaud A-S, Edel J-B. 2014. Palaeozoic evolution of the Variscan Vosges mountains. Geol. Soc. Lond. Spec. Publ. 405: 45-75.

Solar GS, Pressley RA, Brown M, Tucker RD. 1998. Granite ascent in convergent orogenic belts: testing a model. Geology 26: 711-714.

Solgadi F, Moyen JF, Vanderhaeghe O, Sawyer E, Reisberg L. 2007. Mantle implication in syn-orogenic granitoids from the Livradois, MCF. Can. Mineral. 45: 581-606.

Souquet P, Delvolvé J-J, Brusset S. 2003. Identification of an underfilled foreland basin system in the Upper Devonian of the Central Pyrenees: implications for the Hercynian orogeny. Int. J. Earth Sci. 92: 316-337.

Spear FS, Cheney JT. 1989. A petrogenetic grid for pelitic schists in the system $\mathrm{SiO}_{2}-\mathrm{Al}_{2} \mathrm{O}_{3}-\mathrm{FeO}-\mathrm{MgO}-\mathrm{K}_{2} \mathrm{OH}_{2} \mathrm{O}$. Contrib. Mineral. Petrol. 101: 149-164.

Stampfli GM, Borel GD. 2004. The TRANSMED Transects in Space and Time: Constraints on the Paleotectonic Evolution of the Mediterranean Domain. In: Cavazza W, Roure F, Spakman W, Stampfli GM, Ziegler PA, eds. The TRANSMED Atlas. The Mediterranean Region from Crust to Mantle. Berlin, Heidelberg: Springer Berlin Heidelberg, pp. 53-80. https://doi.org/10.1007/ 978-3-642-18919-7 3.

Stampfli GM, Hochard C, Vérard C, Wilhem C. 2013. The formation of Pangea. Tectonophysics 593: 1-19.

Stille H. 1924. Grundfragen der vergleichenden Tektonik. Brontrager Berl. 433.

Suess E. 1883. Das Antlitz der Erde. Vienna: Tempsky F.

Tait JA, Bachtadse V, Franke W, Soffel HC. 1997. Geodynamic evolution of the European Variscan fold belt: palaeomagnetic and geological constraints. Geol. Rundsch. 86: 585. https://doi.org/ $10.1007 / \mathrm{s} 005310050165$.

Tait J, Schätz M, Bachtadse V, Soffel H. 2000. Palaeomagnetism and Palaeozoic palaeogeography of Gondwana and European terranes. Geol. Soc. Lond. Spec. Publ. 179: 21-34.

Talbot CJ. 1979. Infrastructural migmatitic upwelling in East Greenland interpreted as thermal convective structures. Precambrian Res. 8: 7793. https://doi.org/10.1016/0301-9268(79)90039-1.

Talbot J-Y, Faure M, Chen Y, Martelet G. 2005. Pull-apart emplacement of the Margeride granitic complex (French Massif Central). Implications for the late evolution of the Variscan orogen. J. Struct. Geol. 27: 1610-1629.

Thiéry V. 2010. Métamorphismes et déformations des séries cristallophylliennes du Chavanon, de la Sioule et d'Ussel (Massif Central français). Discussion du modèle de nappes du Massif Central. PhD Thesis, Université de Franche-Comté.

Thiéry V, Rolin P, Marquer D, Cocherie A, Fanning CM, Rossi P. 2009. Visean sinistral wrench faulting along the Sillon Houiller in the French Massif Central: Late Variscan tectonic implications. Bull. Société Géologique Fr. 180: 513-528.

Thompson PH, Bard J-P. 1982. Isograds and mineral assemblages in the eastern axial zone, Montagne Noire (France): implications for temperature gradients and P-T history. Can. J. Earth Sci. 19: 129-143.

Thompson AB, Connolly JA. 1995. Melting of the continental crust: some thermal and petrological constraints on anatexis in continental collision zones and other tectonic settings. J. Geophys. Res. Solid Earth 100: 15565-15579.

Torsvik TH, Van der Voo R, Preeden U, Mac Niocaill C, Steinberger $\mathrm{B}$, Doubrovine PV, et al. 2012. Phanerozoic polar wander, palaeogeography and dynamics. Earth-Sci. Rev. 114: 325-368.

Trap P, Roger F, Cenki-Tok B, Paquette J-L. 2017. Timing and duration of partial melting and magmatism in the Variscan
Montagne Noire gneiss dome (French Massif Central). Int. J. Earth Sci. 106: 453-476.

Turpin L, Velde D, Pinte G. 1988. Geochemical comparison between minettes and kersantites from the Western European Hercynian orogen: trace element and $\mathrm{PbSrNd}$ isotope constraints on their origin. Earth Planet. Sci. Lett. 87: 73-86.

Turpin L, Cuney M, Friedrich M, Bouchez J-L, Aubertin M. 1990. Meta-igneous origin of Hercynian peraluminous granites in NW French Massif Central: implications for crustal history reconstructions. Contrib. Mineral. Petrol. 104: 163-172.

Turlin F, Deruy C, Eglinger A, Vanderhaeghe O, André-Mayer A-S, Poujol M, et al. 2018. A 70 Ma record of suprasolidus conditions in the large, hot, long-duration Grenville Orogen. Terra Nova 30: 233-243. https://doi.org/10.1111/ter.12330.

Ueda K, Gerya TV, Burg J-P. 2012. Delamination in collisional orogens: Thermomechanical modelling: Delamination in collisional orogens. J. Geophys. Res. Solid Earth 117. https://doi.org/ 10.1029/2012JB009144.

Unrug R. 1997. Rodinia to Gondwana: the geodynamic map of Gondwana supercontinent assembly. GSA Today 7: 1-6.

Van Den Driessche J, Brun J-P. 1992. Tectonic evolution of the Montagne Noire (French Massif Central): a model of extensional gneiss dome. Geodin. Acta 5: 85-97.

Vanderhaeghe O. 1999. Pervasive melt migration from migmatites to leucogranite in the Shuswap metamorphic core complex, Canada: control of regional deformation. Tectonophysics 312: 35-55.

Vanderhaeghe O. 2009. Migmatites, granites and orogeny: Flow modes of partially-molten rocks and magmas associated with melt/ solid segregation in orogenic belts. Tectonophysics 477: 119-134. https://doi.org/10.1016/j.tecto.2009.06.021.

Vanderhaeghe O, Duchêne S. 2010. Crustal-scale mass transfer, geotherm and topography at convergent plate boundaries: Crustal dynamics at convergent plate boundaries. Terra Nova 22: 315-323. https://doi.org/10.1111/j.1365-3121.2010.00952.x.

Vanderhaeghe O, Teyssier C. 2001a. Crustal-scale rheological transitions during late-orogenic collapse. Tectonophysics 335: 211-228. https://doi.org/10.1016/S0040-1951(01)00053-1.

Vanderhaeghe O, Teyssier C. 2001b. Partial melting and flow of orogens. Tectonophysics 342: 451-472.

Vanderhaeghe O, Burg J-P, Teyssier C. 1999. Exhumation of migmatites in two collapsed orogens: Canadian Cordillera and French Variscides. Geol. Soc. Lond. Spec. Publ. 154: 181-204.

Vanderhaeghe O, Medvedev S, Fullsack P, Beaumont C, Jamieson RA. 2003. Evolution of orogenic wedges and continental plateaux: insights from crustal thermal-mechanical models overlying subducting mantle lithosphere. Geophys. J. Int. 153: 27-51.

Vanderhaeghe O, Prognon F, Gardien V, Solgadi F, Blein O, Watinne A, et al. 2013. Notice de la carte géologique de St Germain Lembron (742).

Vanderhaeghe O, Kruckenberg SC, Gerbault M, Martin L, Duchêne S, Deloule E. 2018. Crustal-scale convection and diapiric upwelling of a partially molten orogenic root (Naxos dome, Greece). Tectonophysics 746: 459-469. https://doi.org/10.1016/j. tecto.2018.03.007.

Vialette Y. 1973. Age des granites du Massif Central. Bull. Société Géologique Fr. 7: 260-270.

Vialette Y, Sabourdy G. 1977. Age du granite de l'Aigoual dans le Massif des Cévennes (France). C R Somm Soc Géol Fr 19: 130132.

Vialette Y, Fernandez A, Sabourdy G. 1979. Age rubidium/strontium de différents plutons du mont Lozère. 
Vielzeuf D, Holloway JR. 1988. Experimental determination of the fluid-absent melting relations in the pelitic system. Contrib. Mineral. Petrol. 98: 257-276.

Vielzeuf D, Vidal P. 2012. Granulites and crustal evolution. Springer Science \& Business Media.

Vielzeuf D, Clemens JD, Pin C, Moinet E. 1990. Granites, granulites, and crustal differentiation. In: Granulites and Crustal Evolution. Springer, pp. 59-85.

Vigneresse JL, Barbey P, Cuney M. 1996. Rheological transitions during partial melting and crystallization with application to felsic magma segregation and transfer. J. Petrol. 37: 1579-1600.

Villaros A, Laurent O, Couzinié S, Moyen J-F, Mintrone M. 2018. Plutons and domes: the consequences of anatectic magma extractionExample from the southeastern French Massif Central. Int. J. Earth Sci. 107: 2819-2842. https://doi.org/10.1007/s00531-018-1630-x.

Vitel G, 1988. Le Granite du Gouffre d'Enfer (Massif Central francais); petrologie d'un marqueur tectonique varisque. Bull. Société Géologique Fr. 4: 907-915.

von Raumer JF, Stampfli GM, Bussy F. 2003. Gondwana-derived microcontinents - The constituents of the Variscan and Alpine collisional orogens. Tectonophysics 365: 7-22. https://doi.org/ 10.1016/S0040-1951(03)00015-5.

von Raumer JF, Finger F, Veselá P, Stampfli GM. 2014. DurbachitesVaugnerites-a geodynamic marker in the central E uropean Variscan orogen. Terra Nova 26: 85-95.

Warren CJ, Beaumont C, Jamieson RA. 2008. Deep subduction and rapid exhumation: Role of crustal strength and strain weakening in continental subduction and ultrahigh-pressure rock exhumation: modelling of uhp exhumation processes. Tectonics 27. https://doi. org/10.1029/2008TC002292.

Watson EB, Harrison TM. 1983. Zircon saturation revisited: temperature and composition effects in a variety of crustal magma types. Earth Planet. Sci. Lett. 64: 295-304. https://doi.org/10.1016/ 0012-821X(83)90211-X.

Weinberg RF. 1997. Diapir-driven crustal convection: decompression melting, renewal of the magma source and the origin of nested plutons. Tectonophysics 271: 217-229. https://doi.org/10.1016/ S0040-1951(96)00269-7.

Weinberg RF. 2016. Himalayan leucogranites and migmatites: nature, timing and duration of anatexis. J. Metamorph. Geol. 34: 821-843.

Weinberg RF, Mark G. 2008. Magma migration, folding, and disaggregation of migmatites in the Karakoram Shear Zone, Ladakh, NW India. Geol. Soc. Am. Bull. 120: 994-1009.

Weinberg RF, Schmeling H. 1992. Polydiapirs: multiwavelength gravity structures. J. Struct. Geol. 14: 425-436. https://doi.org/ 10.1016/0191-8141(92)90103-4.

Weinberg RF, Searle MP. 1998. The Pangong Injection Complex, Indian Karakoram: a case of pervasive granite flowthrough hot viscous crust. J. Geol. Soc. 155: 883-891.
Weinberg RF, Hasalová P, Ward L, Fanning CM. 2013. Interaction between deformation and magma extraction in migmatites: Examples from Kangaroo Island, South Australia. Bulletin 125: 1282-1300.

Whitney DL, Teyssier C, Vanderhaeghe O. 2004. Gneiss domes and crustal flow. Gneiss Domes Orogeny 380: 15.

Whitney DL, Teyssier C, Rey P, Buck WR. 2013. Continental and oceanic core complexes. Bulletin 125: 273-298.

Whitney DL, Roger F, Teyssier C, Rey PF, Respaut J-P. 2015. Syncollapse eclogite metamorphism and exhumation of deep crust in a migmatite dome: The $\mathrm{P}-\mathrm{T}-\mathrm{t}$ record of the youngest Variscan eclogite (Montagne Noire, French Massif Central). Earth Planet. Sci. Lett. 430: 224-234. https://doi.org/10.1016/j. eps1.2015.08.026.

Wickham SM, Oxburgh ER, Reading HG, Vissers RLM. 1987. LowPressure Regional Metamorphism in the Pyrenees and its Implications for the Thermal Evolution of Rifted Continental Crust [and Discussion]. Philos. Trans. R. Soc. Math. Phys. Eng. Sci. 321: 219-242. https://doi.org/10.1098/rsta.1987.0012.

Williams HM. 2004. Nature of the Source Regions for Postcollisional, Potassic Magmatism in Southern and Northern Tibet from Geochemical Variations and Inverse Trace Element Modelling. J. Petrol. 4: 555-607. https://doi.org/10.1093/petrology/ egg094.

Williamson BJ, Downes H, Thirlwall MF. 1992. The relationship between crustal magmatic underplating and granite genesis: an example from the Velay granite complex, Massif Central, France. Earth Environ. Sci. Trans. R. Soc. Edinb. 83: 235-245.

Williamson BJ, Shaw A, Downes H, Thirlwall MF. 1996. Geochemical constraints on the genesis of Hercynian two-mica leucogranites from the Massif Central, France. Chem. Geol. 127: $25-42$.

Williamson BJ, Downes H, Thirlwall MF, Beard A. 1997. Geochemical constraints on restite composition and unmixing in the Velay anatectic granite, French Massif Central. Lithos 40: 295 319.

Wyllie PJ. 1977. Crustal anatexis: an experimental review. Tectonophysics 43: 41-71.

Yakymchuk C, Brown M. 2014. Behaviour of zircon and monazite during crustal melting. J. Geol. Soc. 171: 465-479.

Závada P, Schulmann K, Racek M, Hasalová P, Jeřábek P, Weinberg $\mathrm{RF}$, et al. 2018. Role of strain localization and melt flow on exhumation of deeply subducted continental crust. Lithosphere 10: 217-238. https://doi.org/10.1130/L666.1.

Ziegler PA, Dèzes P. 2006. Crustal evolution of Western and Central Europe. Geol. Soc. Lond. Mem. 32: 43-56. https://doi.org/10.1144/ GSL.MEM.2006.032.01.03.

Zwart HJ. 1967. The duality of orogenic belts. Geol. En Mijnb. 46: 283-309.

Cite this article as: Vanderhaeghe $\mathrm{O}$, Laurent $\mathrm{O}$, Gardien V, Moyen J-F, Gébelin A, Chelle-Michou C, Couzinié S, Villaros A, Bellanger M. 2020. Flow of partially molten crust controlling construction, growth and collapse of the Variscan orogenic belt: the geologic record of the French Massif Central, BSGF - Earth Sciences Bulletin 191: 25. 